Historic, Archive Document

Do not assume content reflects current scientific knowledge, policies, or practices. 



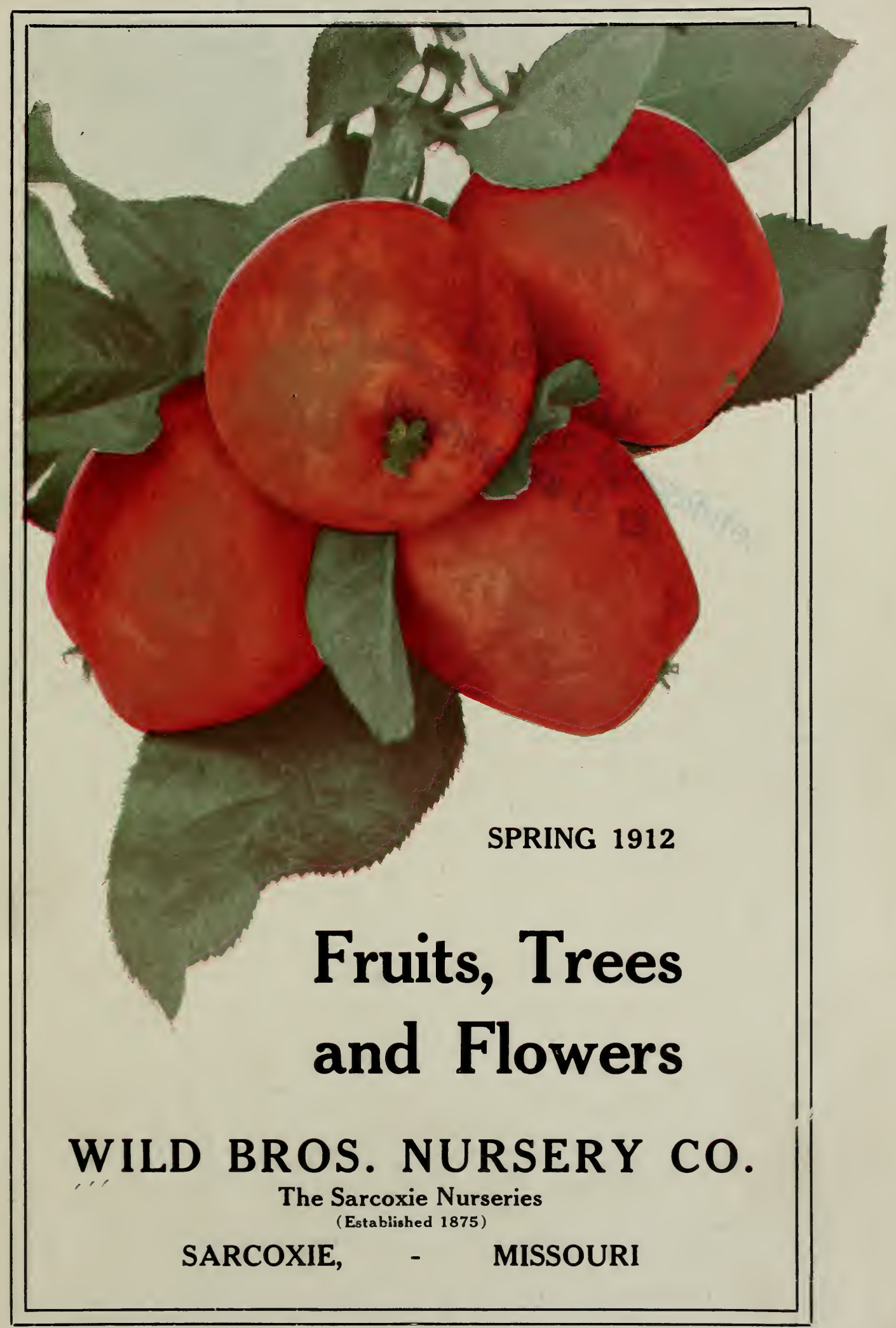




\section{Quality and Price}

$\mathrm{W}$

ITH no class of goods is quality more important. You plant a tree looking forward to a reward in pleasure and profit for years to come. You want a tree well grown, healthy, vigorous, and true to name-price is secondary. Cheapness consists not in what you pay, but in what you get for what you pay. An unusually high price is not necessarily an indication of high quality, - there may be excessive selling expenses. Yet there is a price below which a first class tree cannot be grown.

We make quality and reliability the first consideration. We give the propogation great care, for which we maintain extensive stock blocks. We cultivate frequently, carefully and tlıoroughly. This with our location on the western slope of the Ozark Mountain range, an elevation about 80 feet above St. Louis, our soil and climate, produces a healthy, vigorous, but not forced growth, a tree that is not soft and spongy, but well matured, adapted to North, South, East and West.

Our brick Packing and Cool Storage Building is specially constructed, and equipped with a lighting and water system, which enables us to care for and handle nursery stock in the best possible manner. Special attention is given to careful, thorough packing, as light as is consistent with safety, yet not "skimpy," keeping in view the distance the goods are to travel. We ship long distances, even to foreign countries, with perfect safety.

We employ no agents. When purchasing of us you deal direct with the nursery and pay no agents commissions or other excessive selling expenses, hence our moderate prices. On this basis we solicit your business.

\section{How to Order}

$\mathbf{J}^{\mathrm{sis}}$ UST tell us what you want in any way that suits you best. Make a list of the varieties you want, give number of each, size and price, and tell us whether you wish shipment by freight or express, or wish us to ship as we think best. Nursery stock takes a special rate by express, 20 to $33 \%$ less than merchandise rate, and when shipment is not heavy, we recommend express. If you wish shipment at some special date, tell us. If they can conveniently be obtained, remit by Money Order or Bank Draft, payable to Wild Bros. Nursery Co., these forms of remittance being at our risk. Goods sent C. O. D. when half the amount is sent with order.

Write name and postoffice plainly; if freight or express office is different from postoffice, tell us.

\section{About Substitution}

When this catalog is printed we are prepared to accept orders for all varieties quoted, but as it is impossible to foresee the demand some varieties become exhausted, particularly late in the season. Often customers prefer that a similar variety be sent rather than lose a year in planting. If you do not wish us to do so, write "No Substitution" on order. We prefer that you tell us, otherwise we are obliged to use our judgment. Substitution, as we use the word, means simply that one variety is sent in place of another, correctly labeled with the name of the variety sent. For example, if Mayflower peach was sent in place of Alexander, it would be labeled Mayflower.

TERMS

The prices in this list are under the following conditions and for cash with order As an accomodation, orders from known, responsible, prompt paying customers wil be accepted during shipping season and forwarded to be paid for promptly on receipt of invoice. Parties unknown or with whom we have had no credit transactions, please send cash or references; references delays shipment a few days. Stock ordered reserved for future shipment should be accompanied with one-third the price, balance when shipping date arrives.

ORDERS ARE Only upon condition that they shall be void should injury befall the stock from ACCEPTED frost, hail, storm, fire, or other causes beyond our control. Orders placed early in the season, before full growth and maturity of the stock, are necessarily entered subject to conditions being favorable to produce the required quantity of the grade called for

QUANTITIES Five of a variety at the 10 rate; 50 of a variety at the 100 rate; 500 or over of a variety at the 1,000 rate; less than 5 of a variety at the each rate. This does not mean, as an illustration, that 20 peach, 10 apple, 20 cherry, would be charged at the 100 rate To secure 100 rate it is necessary to order 50 trees or plants of a variety, unless otherwise noted.

GRADING We grade carefully, in some cases by caliper, in others by height; when by both, OF SIZES caliper governs and height is approximate. The lower number is included, the higher number excluded; for example, a grade of 4 to 5 feet includes those trees ranging from 4 up to 5 feet. Should the grade ordered be exhausted, we fill in a larger or smaller grade, charging for the grade sent, unless otherwise instructed. Please state preference.

INSPECTION Copy of certificate of inspection on shipping tag with each shipment.

FUMIGATION Will be done when requested, or when your state requires it.

GUARANTEE While we exercise great care and diligence to have our varieties true to label, and hold ourselves in readiness, on proper proof, to replace any that may prove otherwise, without charge, or refund the amount paid for same, it is mutually understood and agreed between the purchaser and ourselves that this covers the full extent of our guarantee or responsibility.

There are so many conditions over which we have no control-many which no one can controlthat it is impossible to guarantee stock to live, success or failure depending largely on climatic conditions, planting, after care, etc. Occasionally we learn of nurseries who do, but it will be found that + ihe prices more than cover the risk run.

While we cannot assume the expense and risks of transportation, such being beyond our control, if notified in case of delay in transit, we will use our efforts to trace the shipment and hurry it up. CLAIMS For shortage, deductions, or errors, must be made promptly on receipt of goods. Each man who helps fill an order checks for his part, and the packers record their part. Write us just what you received and what the error is as we want to locate the cause and guard against its repetition. Adjustments are easy while the details are fresh in mind. Our customers will assist us in guarding against errors, if they will forward their orders as early as convenient. 


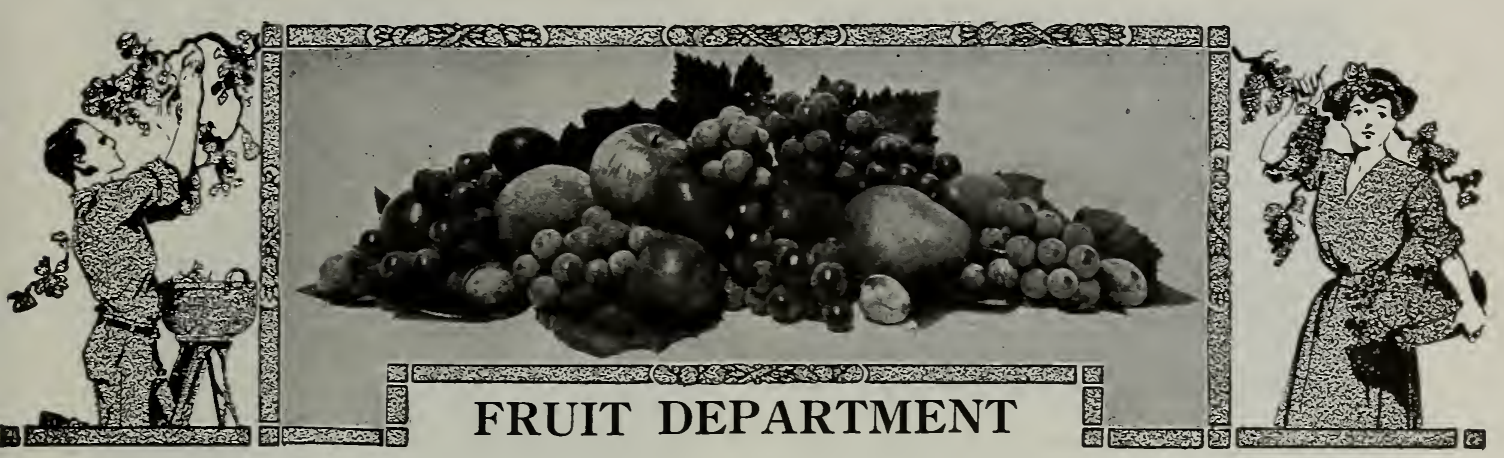

\section{Apple Trees}

$7 \mathrm{HE}$ first fruit in importance is the apple. It is unsurpassed as an article of food and commerce. The varieties to be chosen are governed largely by the use. The home orchard should contain both "cooking" and "eating" varieties. By making a judicious selection a constant succession of fresh apples may be had from early summer till spring, or almost till apples come again. And a moderate home orchard will supply an abundance.

The apple grows best in a deep, rich soil, such as would produce good corn or potatoes. Almost any soil that is not wet can be used for orchard; if hilly, no matter. In fact, the rough, hilly portions of the farm are usually well adapted to fruit and may be made one of the most profitable parts. Preparation of the soil consists mainly in deep, thorough plowing, harrowing and leveling. Plant 20 to 30 feet apart, preferably 30 . The first few years a crop of small fruits, strawberries or regetables may be grown between, not in, the rows.

Our soil does not force a quick, rank growth, therefore we do not get the same height tree at one year as is grown in the rich bottom lands, but our trees mature better and our customers tell us they grow off better in the spring, which is of more importance than height at planting time.

\section{Prices of Apple Trees-Standard Varieties}

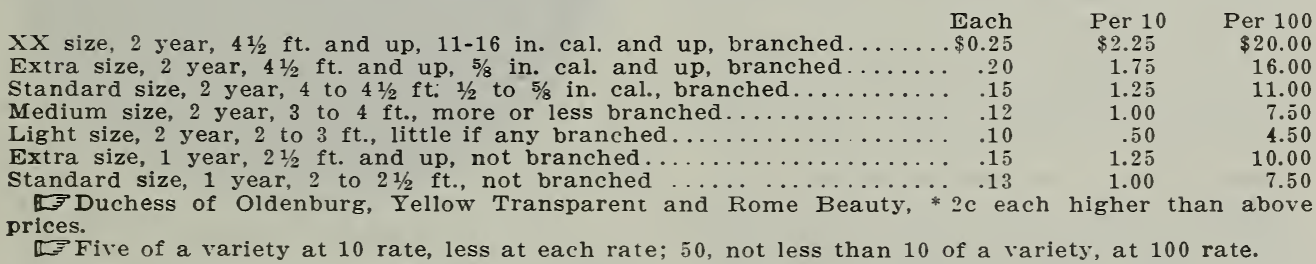

\section{Summer Apples}

Benoni-Medium, roundish, deep red on rich yellow in broken stripes; flesh yellow, tender, juicy, mild sub-acid, of best quality; valuable for dessert or market; early to mid-July.

*Duchess of Oldenburg-Large, red and yellow striped; juicy, rather acid, good; valuable for kitchen and market; vigorous, hardy, early, abundant bearer; July 15-August.

Early Harvest-Medium to large; bright straw color; flesh white. tender, juicy, crisp, rich subacid; productive; June 20-July 10.

Early Ripe-Medium size, roundish-ohlate, broadly ribbed; yellowish-green; sub-acid; good cooking apple; midseason; bears young.

Golden Sweet-Above medium; pale yells, ; flesh tender, sweet, rich, excellent; latter July.

Jeffries-Medium, striped, splashed and marbled red; flesh tender, very juicy, mild sub-acid, delicious; excellent home orchard; Aug.-Sept.; comes into bearing rather early.

Livland Raspberry.-Medium, roundish-conic, beautifully colored, waxen white striped shaded and marbled light crimson; flesh white tint. ed pink, tender, juicy, mild sub-acid, almost sweet; fine; about with or a little later than Yellow Transparent. A Russian variety, very hardy, a young bearer, resistent to blight. Suitable for the north as well as south. Ideal for home use and marketing in baskets or boxes. Rapldly taking the front rank among summer apples.

Red Astrachan-Rather large, roundish-oblate, deep crimson, white bloom; juicy, acid; mid-July, a reliable cropper, bearing young.

Red June-Medium size, oblong, very red, flesh white, tender, sub-acid, good flavor; a young abundant bearer; latter June-July.

Stump-Medium size, oblong-conic, bright red and yellow constrasting beautifully; flesh tender, juicy, rich, aromatic, sprightly subacid; late July-Aug. 1 yr. only.

Summer Queen.--Rather large, roundish-conical, striped bright red on rich yellow; firm, taking the front rank among summer apples. late summer; productive. $1 \mathrm{yr}$. only.

Sweet June.-Medium size, light yellow; flesh vellowish; a very sweet, tender eating apple, fair for cooking; very productive; June-July. 


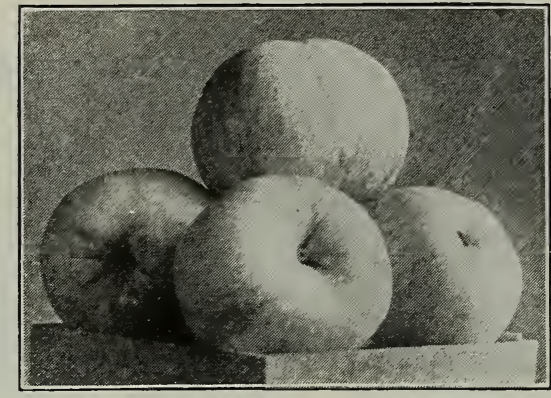

LIVLAND RASPBERRY. (Page 3.)

Tetofski.-Medium size, greenish-yellow attractively striped and splashed crimson; whitish bloom; flesh crisp, juicy, sub-acid, bears very young. June-July.

Wilson June.-Claimed superior to Red June in size and quality, and sweet, ripening later. We have not yet fruited it.

*Yellow Transparent.-Good size, round-conic, waxy yellowish-white; crisp, juicy, sprightly, sub-acid; early bearer; latter June-July.

\section{Autumn Apples}

Fall Pippin.-Large, greenish, becoming attractive yellow; rich sub-acid, good dessert and especially good cooking apple. Sept.-Oct.

Gravenstein.-Large, oblate to roundish, striped bright red on yellow; juicy, sprightly sub-acid; high flavor; productive. Sept.

Oliver.-(Ark.)-Medium to large, yellow mottled and striped with red; sub-acid; sold as Senator by some. Oct.-Dec.

Rambo.-Medium size, yellowish streaked dull red; mildly sub-acid; very crisp, juicy; aromatic; very good; Sept.-Oct., and later.

Ramsdell Sweet.-Good size, oblong, striped dark red with blue bloom; good; Oct.-Nov.

Rutledge.-A red-striped fall apple.

Twenty Ounce.-Very large, greenish-yellow washed, mottled and splashed bright red; juicy, mild sub-acid somewhat coarse grained, but a young, regular bearer; Oct.-Nov.

Wagener.-Medium to large, beautiful bright red with contrasting pale yellow; fine texture, high flavor; very desirable for kitchen and dessert use; bears young; Nov.

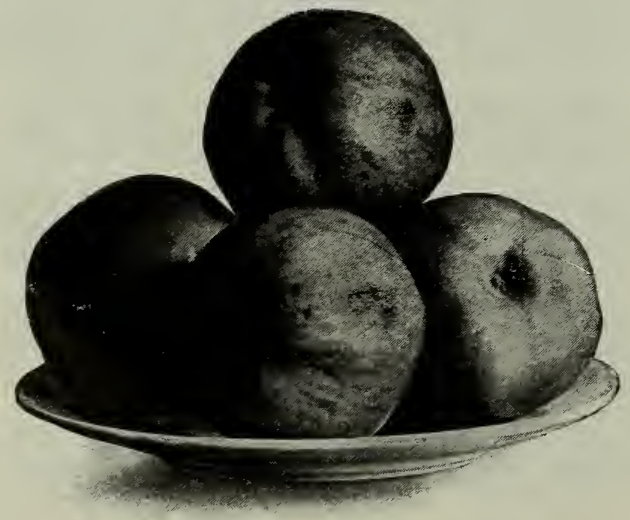

WAGENER.
Wealthy.-Above medium to large, yellow splashed and striped red, total effect bright red; very juicy, agreeable sub-acid, aromatic, very good; very hardy; productive; Sept.-Oct.

\section{Winter Apples}

Arkansas Black.-Medium large, nearly round, prevailing color, lively red deepening to maroon or almost black; flesh decidedly yellowish, rather crisp, moderately juicy, sprightly sub-acid; unproductive in some sections, but always commands a good price where it can be grown; best on bench land; Dec.-Mar., and later.

Baldwin.-Rather large, roundish, yellow mottled bright red; flesh juicy, rich, sub-acid; Dec. early winter or late fall in S. W. Mo.

Ben Davis.-Mottled and striped red on yellow; mild sub-acid; early, abundant bearer.

Boiken.-Medium to large, a very attractive bright yellow with beautiful blush; flesh fine grained, very juicy, brisk sub-acid; bears young.

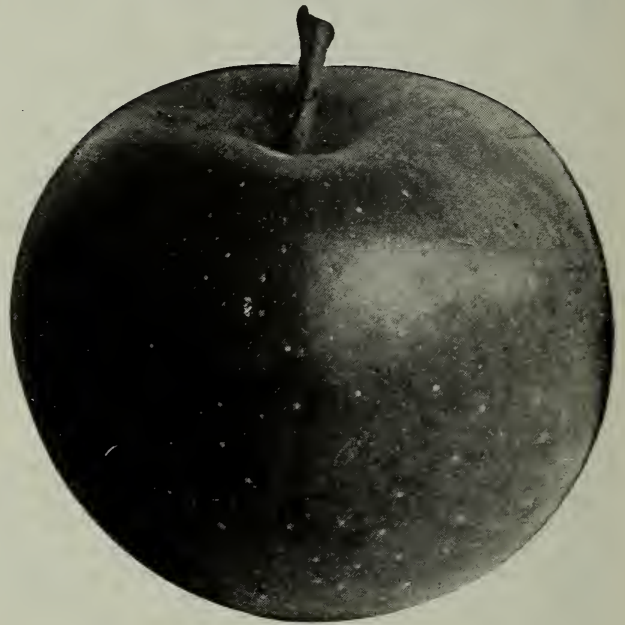

MISSOURI PIPPIN

Collins (Ark.)-Large, globular or a little oblate, inclined to conic, yellow washed and striped red; rather coarse, moderately juicy, sub-acid; midwinter; sold as Champion by some.

Delicious.-Roundish-conic medium to large pale yellow mostly covered with red, splashed and striped dark crimson; mild subacid.

Each Per 10 Per 100

$\mathrm{XX}$ size, 2 year ........\$0.40 \$3.50 $\$ 30.00$

Extra size, 2 year ...... $\quad .30 \quad 2.50 \quad 24.00$

Standard size, 2 year.$\ldots .25 \quad 2.00 \quad 16.00$

Medium size, 2 year ..... 20 . $1.50 \quad 10.00$

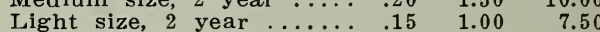

Extra size, 1 year $\ldots . . .6 .20 \quad 1.80 \quad 15.00$

Esopus Spitzenburg.-Large, rich red obscurely striped; excellent flavor and quality; Oct.-Dec.; a Washington and Oregon favorite.

Gano.-Large, oblate to conical; rich red to maroon, rarely striped; flesh white, mild subacid; late winter; of the Ben Davis type.

Geneton.-Roundish; pale red stripes on light yellow; fine grained, juicy, fine mild sub-acid with a slight mingling of sweet; aromatic; medium size; keeps through spring; a late bloomer and profuse bearer. 1 yr. only.

Grimes' Golden.-Medium to large; beautiful rich golden yellow; crisp, juicy, rich, sub-acid; aromatic; very good to best; early bearer; Oct.Dec., good for cooking even before it colors. 


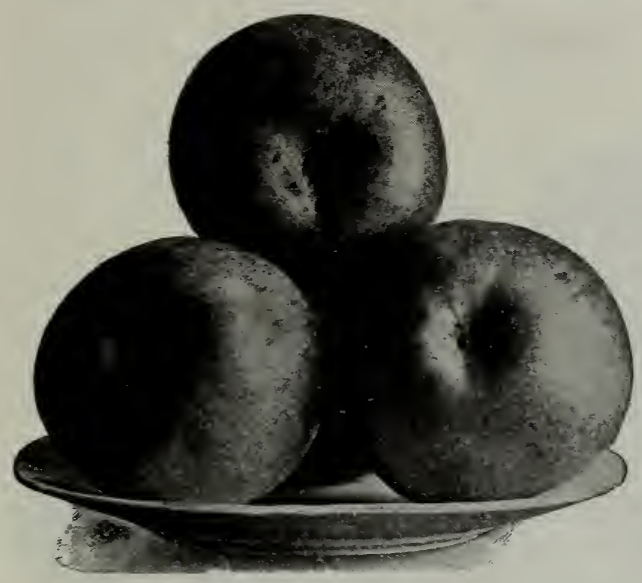

YORK IMPERIAL

Ingram.-Medium; dark and light red in stripes; firm, juicy, very mild sub-acid, good; blooms late; largely planted for keeping qualities; seedling of Geneton, better color.

Iowa Blush.-Medium size, yellow blushed red; fine grained, juicy, subacid, good; midwinter.

Jonathan.-Medium size unless thinned; color lively, deep red; flesh tender, crisp, juicy, very aromatic, sub-acid; very good to best; dessert kitchen, market; Oct. and later.

Kinnard's Choice.-Medium to large, dark red on yellow; beautiful, showy; agreeably sub-acid, somewhat aromatic; quality one of the best; vigorous, bears young; Winesap type.

Little Red Romanite.-Small to medium, striped red on yellow; firm, mild, sub-acid, almost sweet; late keeper; early, annual bearer.

McIntosh.-Good size, rery attractive appearance; general effect, bright deep red; flesh varv tender. nerfumed, delicious; resembles Fameuse, but larger. Nov.-Jan. 1 yr. only.

Mammoth Black Twig.-Large, roundish, inclined to conic, greenish, lairgely overspread dull deep red, on some soils almost dark as Ark. Black; flesh tinged yellow, firm, rather tender, moderately juicy, sub-acid; Dec.-Mar.

Missouri Pippin.-Large, attractive bright red striped darker; flesh firm, briskly sub-acid, fair; good grower. Nov.-Jan., a young, heavy bearer, extensively planted for quick results.

Newtown Pippin.-Medium to large, greenish-yellow, often brownish-red cheek: flesh firm, tender, rich, aromatic, sub-acid, of highest quality; Dec.-Feb.; a late keeper.

Northern Spy.-Large, pale yellow, nearly concealed with purplish red; crisp, juicy, excellent quality, prune to an open top; Oct.-Dec.

Patten Greening.-Nledium to large, attractive, pale greenish-yellow, sometimes blushed, occasionally faintly striped; juicy, sub-acid, good, especially for cooking; very hardy; an annual cropper, bearing rather young.
Reagan (Ark.)-Large, oblate to conical, rich red to maroon, rarely striped; flesh white, mild sub-acid; late winter; sold as Black Ben Davis by some.

*Rome Beauty.-Large, mottled, shaded and striped bright red; juicy, aromatic, mild subacid; good; early winter; a good shipper; blooms late; bears young and heavily.

Stayman Winesap.-Large, greenish-yellow splashed and striped red, often nearly covered; fiesh tender, juicy, aromatic, sprightly, pleasant sub-acid; good to very good; late.

Virginia Beauty.-Medium size, greenish-yellow and dull red; juicy, sweet, late.

White Winter Pearmain.-Medium to large, yellowish, brownish-red cheek; fine grained, crisp, juicy, mild sub-acid, aromatic; late.

Winesap.-Roundish, slightly conical, bright deep red on yellow; flesh yellow, very juicy, crisp, sub-acid; rich; very good; Dec.-Mar.

Winter Banana.-Large, clear pale, waxy yellow with beautiful contrasting pinkish red blush, attractive, juicy, mild sub-acid, characteristically aromatic; good dessert quality; flesh moderately firm, somewhat crisp, tender, juicy; vigorous, a young and almost annual bearer of good crops.

Wolf River.- Very large, round-oblate, yellowish mottled and splashed bright red; subacid; early winter here.

Yellow Bellflower.-Large, oblong-ovate, bright pale yellow often blushed; flesh firm, crisp, juicy, acid to mild; Nov.-Dec.

York Imperial.-Large, roundish oblate, often oblique, yellowish shaded red and crimson: juicy, sub-acid becoming mild; good; Dec.

\section{Crab Apple}

Florence.-Large, yellowish-white, beautifully striped and overspread bright red, juicy, crisp, brisk, sub-acid, good; a young, reliable cropper, very prolific, early August.

Martha.-Large, soft, creamy yellow, overspread with attractive bright, light red; crisp, juicy, brisk sub-acid, good to very good, young, profuse annual bearer.

Red Siberian.-Small, in clusters, yellow, scarlet cheek, astringent; much used for preserving whole; bears very young; early Aug.

Transcendent.-Medium large, golden yellow with rich crimson cheek; white bloom; juicy, sub-acid; hardy, very productive, Aug.-Sept.

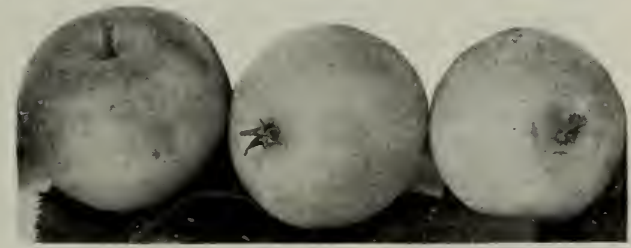

TRANSCENDENT CRAB

\section{Miscellaneous Fruits and Nuts}

Pawpaw.-Fruit peculiar looking, cylindrical, 3 to 5 inches long; flesh deep creamy yellow, soft, very sweet. Several trees should be planted together. Each Per 10 Per 100

5 to 6 feet........ $\$ 0.30 \quad \$ 2.50$

4 to 5 feet........... $\quad .25 \quad 2.00 \quad \$ 15.00$

3 to 4 feet............

Persimmon.-Sweet, melting and delicious when ripe. The fruit is now frequently seen on city markets. Several trees should be planted together. Seedlings of Early Golden.

Each Per 10

Per 100

$\$ 8.00$
Sarvis (Dwarf June Berry).-Fruit blue-black. sweet, juicy, as large or larger than good sized currants, produced in profusion.

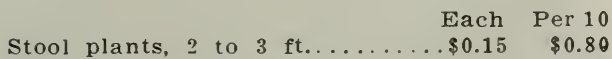

Stool plants, 1 to $2 \mathrm{ft} . \ldots \ldots \ldots \ldots . .10 \quad .60$

Walnut, Black.-See page 21.

Apricots, Russian- Each Per 10

Extra size ............... \$0.30 \$2.50

Standard size ............... $25 \quad 2.00$

Medium size ............... .20 1.80 


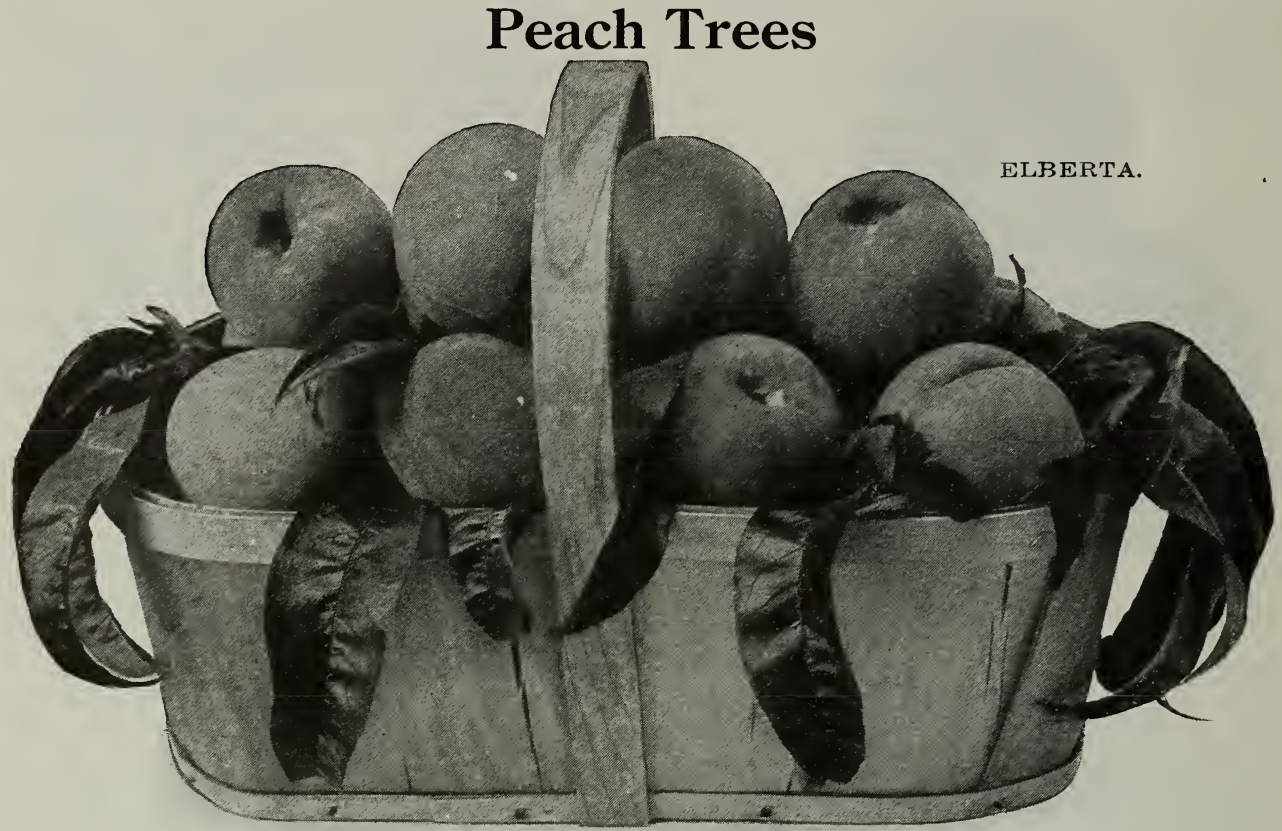

$\mathrm{T}$

HIS daintiest of fruits, given proper care, is one of the most profitable. No fruit commands better prices in its season. In the home orchard it is indispensible. A sandy loam or gravely soil is best but the peach will adapt itself to any soil not wet. A northern slope is preferable to southern, as it retards early blooming. Plant 16 to 18 feet apart, requiring 134 to 170 trees per acre. Cut back to 20 to 26 inches if a low headed tree is desired. After growth is started, remove all but three or four branches, distributed as equally as possible to secure a well balanced tree. Perhaps the best cultivation is frequently shallow stirring of the soil until July or August, followed by a green cover crop turned under in the spring.

These varieties are successful over a wide range of territory and include the leading market sorts.

Price of Peach, except as otherwise noted. Each Per 10

$\$ 2.50$

Per 100

XXX size, 1 year, $41 / 2 \mathrm{ft}$, and $\mathrm{up}$, extra heavy ..............\$0.30

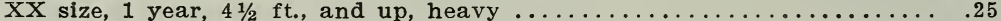

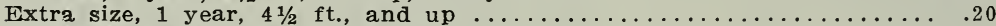

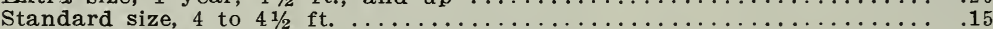

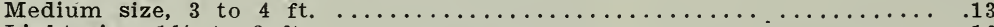

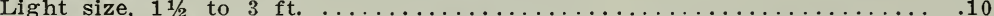

2.00

$\$ 20.00$

$1.50 \quad 12.00$

$1.25 \quad 10.00$

$\begin{array}{lr}1.00 & 7.00\end{array}$

$.60 \quad 5.00$

留 Five of a variety at 10 rate, less at each rate; 50 , not less than 10 of a variety, at 100 rate.

Arkansas Mammoth Cling.-Large, white with faint blush; juicy, good; latter Sept.

Belle of Georgia.-Very large, white with red cheek; flesh white, firm, excellent flavor; very prolific; excellent shipper; freestone; ripens with Crawford's Early or before.

Carman.-Large, creamy white or pale yellow splashed red; flesh white, tender, melting, rich, sweet; semi-cling; early market; prolific.

Champion.-Large, white with beautiful red cheek; flesh white, sweet, rich, juicy; delicious flavor; freestone; early Aug.; bears young.

Crawford's Early.-Very large, oblong, yellow with red cheek; flesh yellow, slightly subacid; excellent flavor; freestone; early Aug.

Crawford's Late.-Very large, yellow, deep red cheek; flesh yellow, juicy, rich; freestone; latter Aug.-Sept.; good market peach; vigornus.

Crosby.-Medium size, orange-yellow splashed red; flesh yellow, red at pit, juicy, rich; latter Aug., prolific; especially hardy.

Elberta.-Very large, yellow, red cheek; flesh yellow, firm, juicy, good; freestone; mid-August; the most extensively planted shipping variety.
Family Favorite.-Large, white, red blush; flesh white, Juicy, good; freestone; early Aug.; prolific; making a good record everywhere.

Greensboro.-Large, colored beautifully with crimson with yellowish cast; flesh white, very juicy, excellent; semi-cling; mid-June; a profuse bearer.

Guinn.-Large, becoming very bright red k.efore ripe, hence a good shipper; largely planted in Southern Texas.

Heath Cling.-Very large, oblong-oval, point prominent; creamy-white, faint blush on exposed specimens; flesh white to the stone, rich, juicy, sweet, of finest flavor; latter Sept.

Henrietta.-Very large, yellow nearly covered with bright crimson; cling; hardy prolific; late.

Hiley-(Early Belle.)-Large, white, beautiful red cheek; flesh white, good, prolific; ripens before Belle of Georgia.

Indian Blood Cling-Dark scarlet with veins; downy; flesh deep red, Juicy; good; Sept. $5 \mathrm{c}$ each higher than above prices.

Iron Mountain.-The latest white-fleshed freestone.

Kalamazoo.-Medium size, yellow shaded red, high quality; freestone; growth strong, a young. heavy bearer, and very hardy; latter $\Lambda$ ug. 
Krummel's October.-Large; fine yellow with red cheek; flesh yellow, red at pit, juicy, sweet; freestone; latter Sept. to Oct.

Large Indian Cling.-Large, real red-fleshed Indian Cling. $10 \mathrm{c}$ each higher than above.

Mayflower.-Red all over: "the earliest of all peaches," about June 10; reported by commercial growers the most profitable extra early peach, especially for express shipments.

Munson Cling.-An Elberta Cling in season of ripening, fully as large or larger; orange yellow, half covered with bright crimson mottling: flesh yellow firm as Elberta, better quality.

Munson Free.-An Elberta seedling, larger, a week later, better quality; more prolific; flesh rellow.

oldmixon Cling. - Large creamy white with a red cheek; flesh white, red at pit, juicy rich high flavor; latter Aug.; prolific; one of the best, if not the very. best clingstone.

Salway.-Large, yellow w it h brownish red cheek; flesh yellow firm, juicy, sweet, good: freestone; a good shipper and profitable late market peach; late sept. to early Oct.

Stump. the World.Large, creamy white, bright red cheek; flesh white, juicy, excellent; freestone; late August to September; productive.

Texas King.-Creamy white, nearly covered with delicate carmine; adheres slightly; larger than Mamie Ross and a few days later; mid July; hardy in bud, an abundant bearer.

W $h \otimes 1 \oplus \mathbf{r}$ Large, wh it e, blush c h e e k: flesh white, firm: better qu a lit y than Alexander: cling; an extra early $\mathrm{mar} k \mathrm{et}$ peach of merit.

BELLE OF GEORGIA

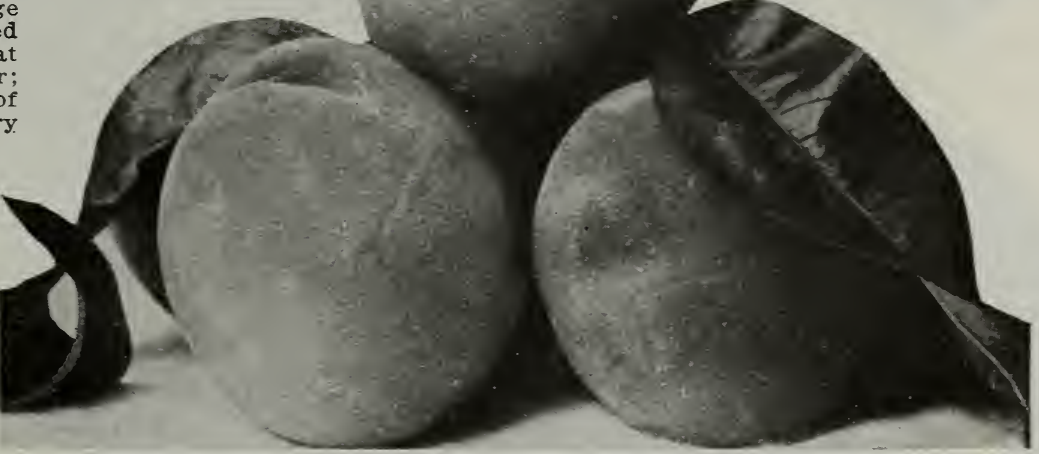

Plum Trees

$\mathrm{P}$ LUMS will succeed in almost any kind of soil, in this adaptability ranking probably next to apple. It is usually considered that the European class prefer rather heavy clay loam, or at least are not their best on light, sandy soils, while the Japanese type with a moderate amount of sand. The Wild Goose group is most successful on rich, sandy lowland, but have a wide range of adaptability to various soils. In general plant 18 to 20 feet apart. Mixed home orchards may be closer. If a power sprayer is to be used, not less than 20 feet one way. For best results several varieties should be planted, as some are not good self-pollenizers.

Plums require less regular pruning than apples. As a rule all that is necessary is to keep the tree well shaped, and trim back too vigorous growers. The principal insect enemy, curculio. may be kept in check by jarring them off on cloths so they may be destroyed. Spraying with arsenates just before the blossoms open and a week after they fall is beneficial.

Prices of Plum. Deck's Damson 5̃e each higher. Extra size, 4 16 ft, and up, branched Each $\cdot$ Per 10 Per 100

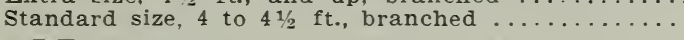
$\begin{array}{rr}\text { Each } & \text { Per } 10 \\ \$ 0.30 & \$ 2.50\end{array}$ $\$ 22.00$

America.-About the size of Wild Goose, golden yellow with pink blush; a young, abundant bearer; cling; a Japan-American hybrid.

\section{Abundance (Botan) (Japan.)-Medium to}

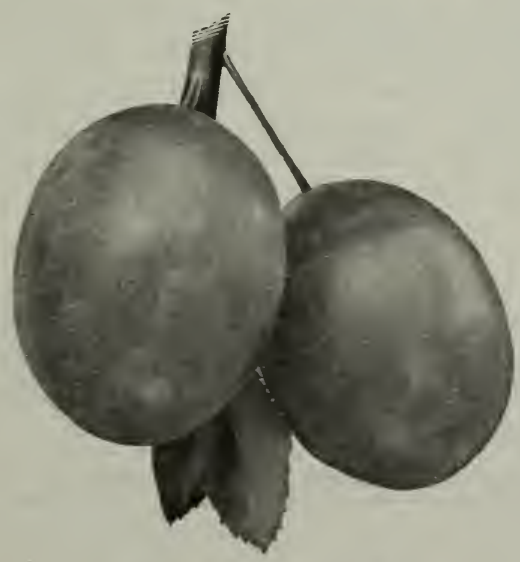

EUROPEAN PLUM large, bright red over yellow, dots many; sweet, rich, cling, hardy, bears young, early July.

Burbank (Japan).-Large to very large, bright metallic red on yellow: flesh yellow, firm, juicy, rich, sugary, cling, good to very good, bears profusely, requires thinning; latter July.

Deck's Damson (European.)-An improvement on common Damson, a little larger; dark purple; most productive of any Damson we have fruited here; when fully ripe parts readily from pit. Aug.-Sept.

Gonzales.-Large, bright wine red, indistinctly striped deep crimson; flesh light red, sweet, pleasant. cling; quality first rate.

Red June (Red Nagate) (Japan).-Medium to large, dark ooppery red, bluish bloom; flesh yellow; juicy; early, before Abundance; free grower; semi-cling.

Shipper's Pride (European).-Large, nearly round, dark purple or blue; flesh firm, excellent: early Sept.

Shropshire Damson (European).-Iarge for a Damson, dark blue: esteemed for preserving: latter sept.; tree vigorous.

Wickson (Japan).-Large, heart-shaped, dark red with thick bluish bloom; flesh yellow, solid, meaty, sweet, good; cling.

Wild Goose.-Oval, medium to large, cherry red, many white dots; sweet, good; cling; vigorous, requires cross-pollenization; early July. 


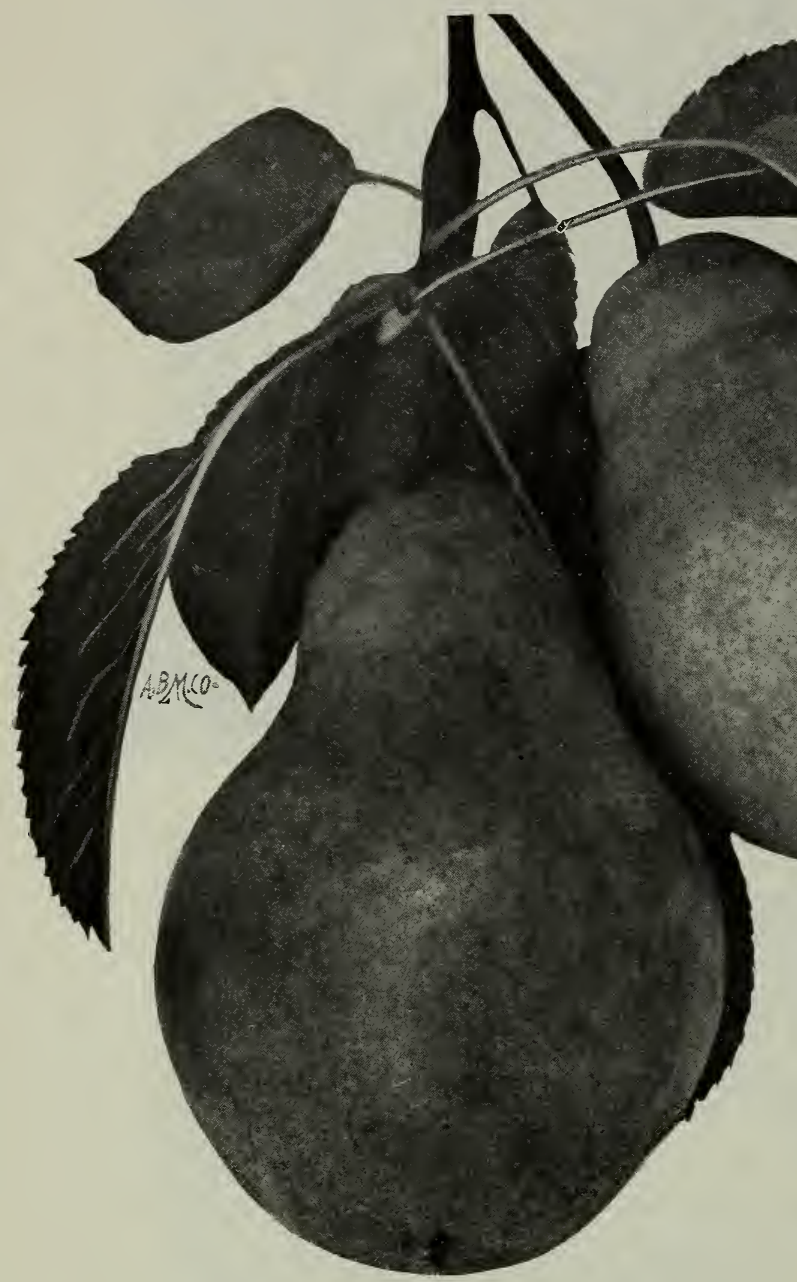

BARTLETT

Anjou.-Large, greenish-yellow, russet and red cheek; flesh fine grained, buttery, melting, high, rich, vinous flavor; late Sept.

Bartlett.-First quality; large, waxy yellow, a blush on sunny side; flesh fine grained, rich, rather musky flavor; latter Aug.; productive, bears young. 5c each higher than above.

Clapp's Favorite.-Large, yellow, dotted and shaded red on sunny side; flesh juicy, melting, perfumed; latter July-Aug.; gather early.

Duchess D'Angouleme.-Very large, greenishyellow with russet patched and dull red cheek; juicy, melting, slightly granular; Sept.-Oct.; productive.

Garber.-Large, round, waxen yellow; fine for canning; noted for its vigor and freedon from blight; Sept.; before Kieffer.

Seckel.-Small but of highest flavor; brownish-green becoming yellowish-brown; flesh fine grained, sweet, very juicy, melting; early Sept.

\begin{abstract}
THE home orchard is incomplete without pears and $t h$ e $y$ are a staple and profit a ble commercial crop in nearly all parts of the c o u t ry. While Pears will thrive on a variety of soils iney succeed best in a rather hard, clay soil, which rather retards a too rank growth. Tilling and fertilizing are an advantage, but should not be carried so far as to produce too vigorous a growth and fertilizers should not be too rich in nitrogen, as rank growth favors attacks of blight. If at any time this appears, cut back into s o u n d wood and burn the clippings. The pear bears on spurs and these should not be removed in pruning unless the tree is bearing too heavily. The quality is much improved by proper ripening indoor, the early varieties being gathered about ten
\end{abstract} days before maturity, autumn varieties two weeks, and winter varieties left on the trees as long as possible before the leaves begin to fall. Place them in a cool place, sorting occasionally.

Price of Pear, (Bartlett 5c each higher.)

Each Per 10 Per 100 XX size, $5 / 8$ to $3 / 4$ inch caliper

4 to 6 feet ............. $\$ 0.30 \$ 2.50 \quad \$ 22.00$ Extra size, $1 / 2$ to $5 / 8$ inch cali-

per, 4 to 5 feet $\ldots \ldots \ldots \ldots \ldots, \quad .25 \quad 2.00 \quad 18.00$

Five of a variety at 10 rate, less at each rate; 50 , not less than 10 of a variety, at 100 rate.

The height will vary some with the variety.

Kieffer.-Large to very large; rich yellow tinted red; flesh juicy, usually slightly coarse, variable in quality; develops good flavor if ripened slowly in the dark; excellent for canning; vigorous, very productive; Sept.-Nov.

Wilder Early.-Medium, greenish-yellow, brownish-red cheek; flesh fine grained, tender, juicy, excellent; July-Aug.

\section{Dwarf Pear}

Dwarf Pears, propagated by budding on Quince, are valuable where space is limited and begin bearing younger than the standards, though they are not so long lived. Should be planted 4 to 6 in. deeper than in the nursery, will then finally become half standards. Usual distance 10 to 12 feet.

Duchess D'Angouleme. $-5 / 8$ to $11-16$ in. caliper, 25 cents each, $\$ 2.00$ per $10 . \$ 16.00$ per 100 


\section{Cherries}

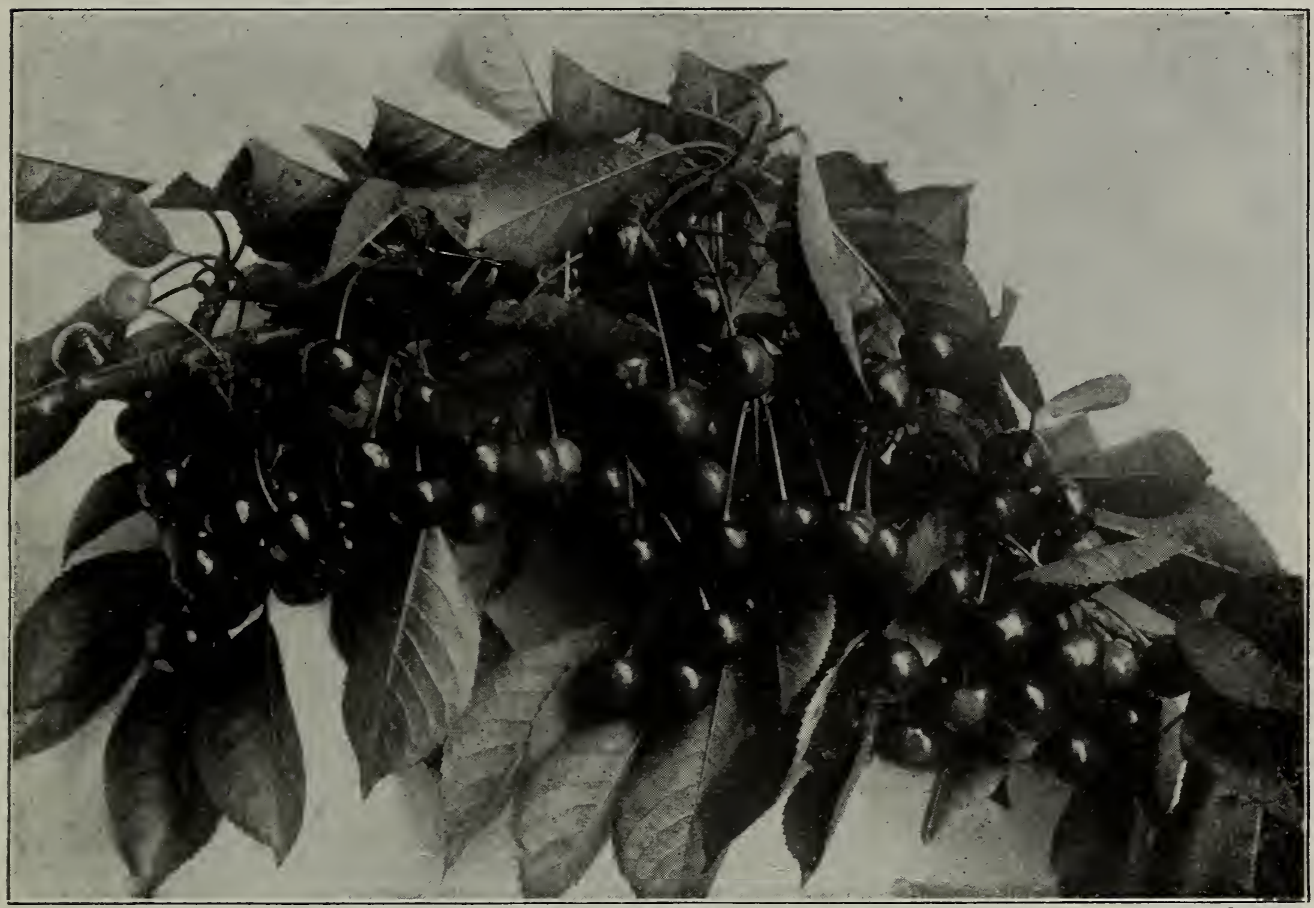

EARLY RICHMOND, One of the Most Productive Cherries.

$\mathrm{O}$ NE of the most popular fruits, its hardiness, good habit and the fact that it bears annually are strong recommendations. Cherries are very profitably grown for market, coming in just at the close of the strawberry season, well grown trees producing from 3 to 5 crates of 24 quarts, which readily sell at $\$ 2.00$ to $\$ 3.00$ per crate. And the demand seems to increase faster than the supply. Set 18 feet apart requires 134 , or 20 feet apart requires 108 tree per acre. They will grow on thinner soil than most other fruit trees, though to obtain the finest fruits, a deep, mellow soil of good quality is desirable. A dry soil is everywhere conceded. On wet soil the tree is apt to be short lived. Planted in the dooryard it becomes an ornament both when in bloom and when loaded with its beautifully colored fruit. Cherries are always needed for home use and any surplus finds a ready sale.

Our cherry trees are budded on Mahaleb stoclss, which do not throw sprouts from the roots. The varieties offered are the most successful over a wide extent of territory. We do not offer sweet cherries as they are successful only in a limited territory. If you have cherry trees that do not bear, perhaps you have sweet varieties and your locality is not favorable for them. Royal Duke is the nearest a sweet cherry that is a success here.

Plant cherry early for best results. Severe pruning should not be done either when planting or in subsequent years. Keeping the tree well shaped is about all that is required.

Prices of Cherry.

Each

Per 10 Per 100 $\mathrm{XXX}$ size, 2 yr. $3 / 4$-in. caliper up, 5 to $6 \mathrm{ft}$., branched .......... $\ldots 0.50 \quad \$ 4.50$ $\mathrm{XX}$ size, 2 yr., $4 \mathrm{ft}$. and up, $5 / 8$ inch caliper, branched..............40 Extra size, 2 year, 3 to $4 \mathrm{ft} ., 1 / 2$ to $9-16$ inch caliper, branched....... $.30 \quad 22.00$

Five of a variety at 10 rate, less at each rate; 50 , not less than 10 of a variety, at 100 rate.

Dyehouse.-Ripens before Early Richmond; productive; a very early, reliable bearer; May.

Early Richmond (May Cherry).-Medium size, round, bright red, darker when fully ripe; melting, very juicy, sprightly, acid; hangs long on the tree; very productive; latter May-June.

English Morello.-Large, dark red, nearly black; flesh dark purplish-crimson, juicy, rich acid; prolifio: latter June-July; tree dwarfish.
Montmorency Ordinaire. - Medium large, dark rich red; a fine acid, very good; later than Early Richmond; a good market variety, and the best of the Montmorency type. Sometimes sold as Montmorency King.

Koyal Duke.-Very large, dark red; flesh reddish, tender, juicy, rich; middle to latter June. jc each extra if ordered without other cherry. 


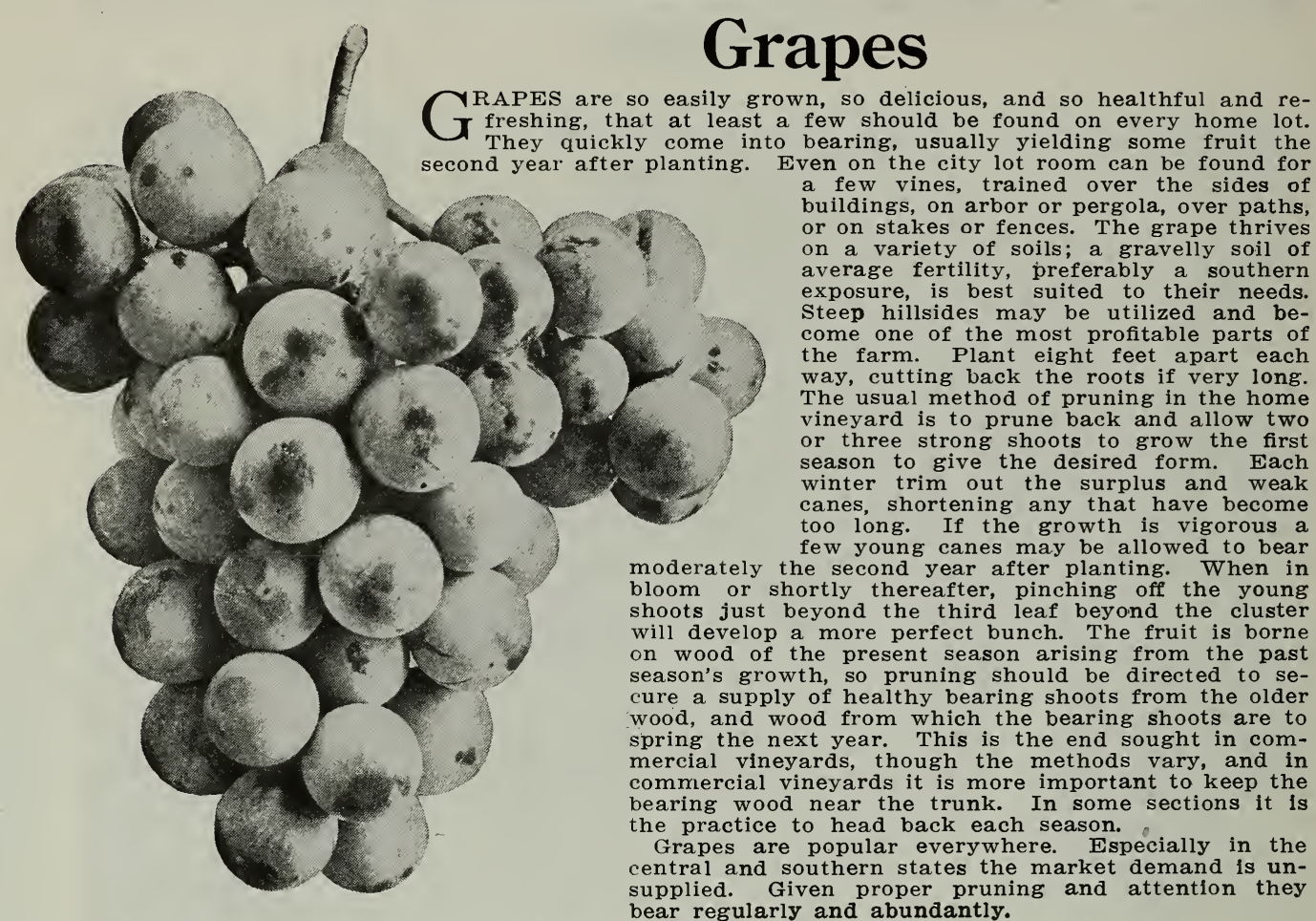
bear regularly and abundantly.

Commercially no fruit except the strawberry gives quicker returns on the investment.

Five of a variety at the 10 rate, less at each rate; 50 of a variety at the 100 rate. In lots of 500 or more, send us a list of your wants for quotations.

Aroma.-A new Western variety; red; bunches medium, berries very large; very aromatic, a basket scenting a large room; while it has some foxy flavor, the growth is vigorous, foliage healthy, it is very resistent to rot, and very productive; should be heavily pruned to prevent overproduction. A few vines will be appreciated in almost any home vineyard.

Each Per 10 Per 100

Two year $\ldots \ldots \ldots \ldots \ldots \$ 0.15 \quad \begin{aligned} & \text { Pach } \\ & \$ 1.20\end{aligned} \quad \begin{aligned} & \text { Per } 100 \\ & \$ 10.00\end{aligned}$

Campbell's Early.-Black; bunch large, usually shouldered; berries large, nearly round, with purple bloom; flesh rather firm, but tender, sweet, juicy; ripens with or before Moore's Early. Aug. 5-10; prune heavily to prevent overbearing.

Each Per 10 Per 100

Concord. Black, deservedly the most popular grape in the market; bunch compact, large; shouldered; berries large, with a rich bloom; skin tender; flesh juicy, sweet; Aug. 15-25; a strong grower, hardy, healthy, productive.

Two year ........\$\$ Each $\begin{array}{cr}\text { Per } 10 & \text { Per } 100 \\ \$ 0.60 & \$ 4.00\end{array}$

Early Ohio.-The earliest good black grape; about ten days before Moore's Early; bunch large, compact, shouldered; berry medium, heavy bloom, adheres firmly; vigorous, productive.

$\begin{array}{rlr}\text { Each } & \begin{array}{r}\text { Per } 10 \\ \text { Two year } \ldots \ldots \ldots \ldots \ldots 0.20\end{array} & \begin{array}{r}\text { Per } 100 \\ \$ 1.50\end{array}\end{array}$

Ives.-Black; bunch medium to large, compact; thick, tough skin; berries medium; slightly oblong, sweet; colors first week in Aug., but not fully matured for several weeks; productive; very free from rot; valuable for market; a good grower; hardy.

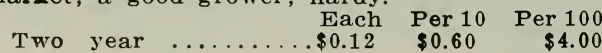

Lutie.-Red; medium quality, foxy, but vigorous, productive, and seems to be well regarded South; ripens with Moore's Early.

Each Per 10 Per 100

Moore's Diamond.-Bunch large, compact, shouldered; berries large, yellowish-green; skin thick; flesh tender, juicy, good; mid-Aug.; a good grower, hardy, productive.

$\begin{array}{lllr}\text { Two year } \ldots \ldots \ldots \ldots \ldots \$ 0.12 & \begin{array}{l}\text { Per 10 } \\ \$ 0.80\end{array} & \begin{array}{r}\text { Per } 100 \\ \$ 6.00\end{array}\end{array}$

Moore's Early.-Bunch medium; berries large, black with heavy bloom; skin thin; flesh sweet; about 10-14 days before Concord; its season, size and hardiness makes it desirable both for home use and market.

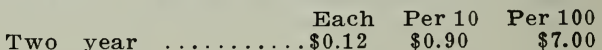

Niagara.-Bunch large, long, sometimes shouldered; berries large, greenish-white to pale yellow; skin thin, tough; ripens with Concord or a little later; good for table or market; vigorous, very productive; the White Concord.

Each Per 10 Per 100

Worden.-Black; bunches large, shouldered, compact; berries large, skin thin, quality good; earlier and better than Concord; Aug. 10-20; vine a good grower, hardy, productive.

$\begin{array}{rrrrr} & \text { Each } & \text { Per } 10 & \text { Per } 100 \\ \text { Two year } \ldots \ldots \ldots \ldots \$ 0.12 & \$ 0.80 & \$ 7.00\end{array}$

Wyoming.-A very early red grape; larger than Delaware; flesh tender, juicy, sweet; vine healthy, hardy, a good grower, productive.

Two year ........ Each $\begin{gathered}\text { Per } 10 \\ \$ 0.80\end{gathered} \quad \begin{array}{r}\text { Per } 100 \\ \$ 6.00\end{array}$ 


\section{Gooseberries}

THIS is another fruit for which there is always a good demand. They require same cultivation and planting as currants, except that plants may be set in the open field or garden, though a north slope is preferable. Plant $3 \times 5$ or $4 \times 5$ feet apart, requiring 2900 or 2178 plants per acre. They bear most freely on 2 and 3 year wood, so pruning should maintain a continuous supply of vigorous wood. Much of the disappointment in growing gooseberries has been due to using English varieties, which in America are especially subject to mildew. We offer only American varieties.

Houghton.-Glossy, pale dull reddish-brown; flesh tender, juicy pleasant; berry rather small, but a profuse bearer, very free from mildew, of easy cultivation. The best for most sections.

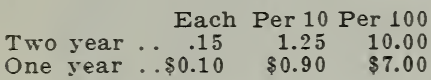

\section{Currants}

UURRANTS ripen partly with Raspberries and follow for several weeks. None of the

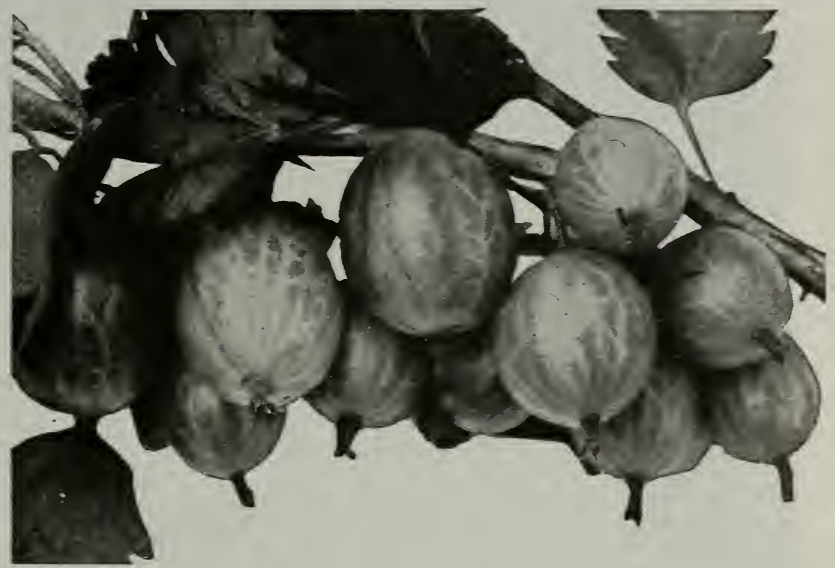
small fruits remain longer on the

bush without injury. Give them a Northern exposure or partial shade such as a North side of a fence or building. In the home garden they may be grown in almost any soil. For commercial purposes select preferably a strong, moist loam, with considerable admixture of clay. Even a stiff clay w1ll do if well drained. Set $2 \times 3 \frac{1 / 2}{2}$ to $3 \times 4$ feet apart; cultivate well, but shallow; mulch heavily: manure freely. Prune all wood over three years old away allowing remaining shoots room to grow and maintain a supply of new growth, one and two year wood.

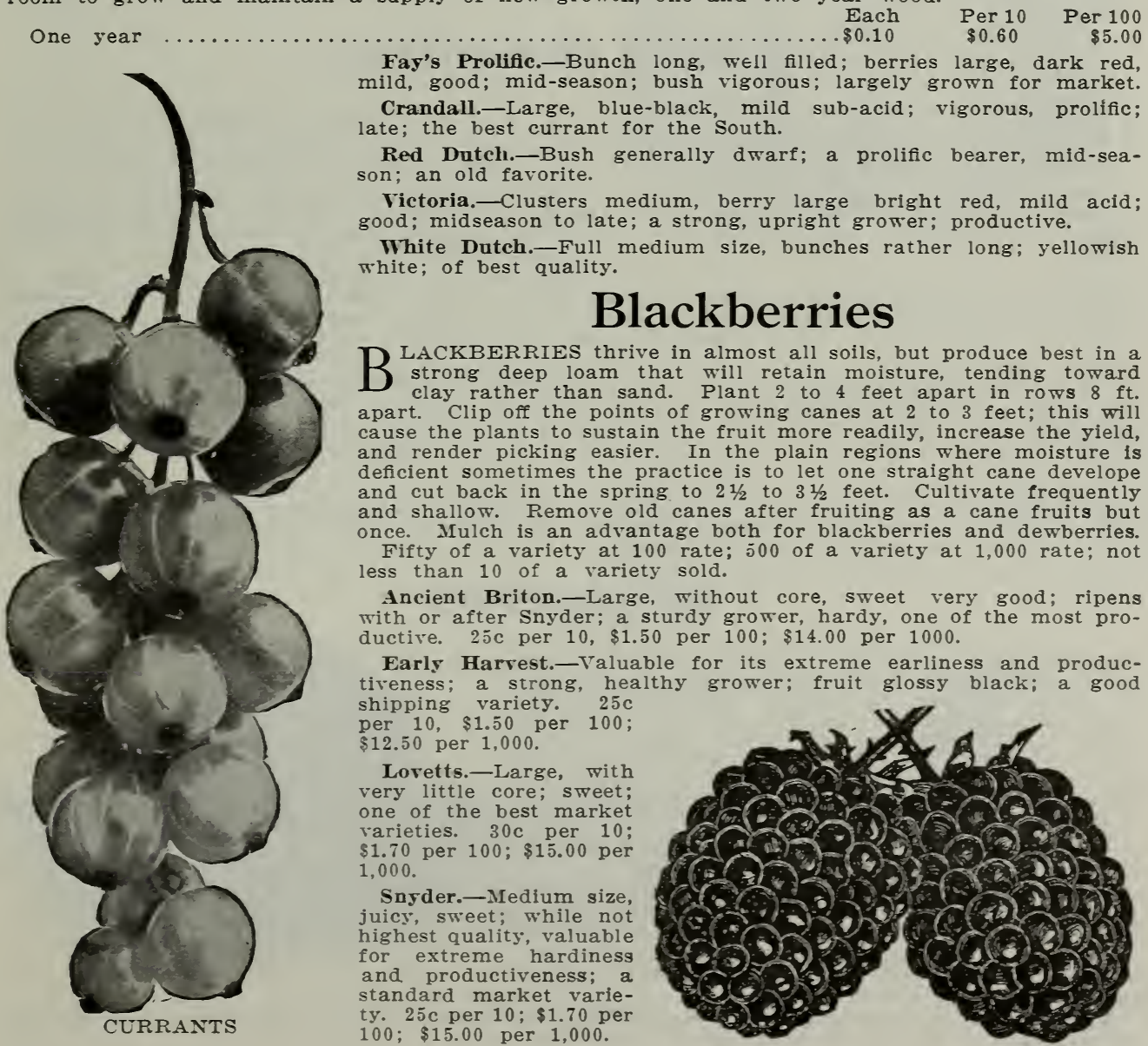




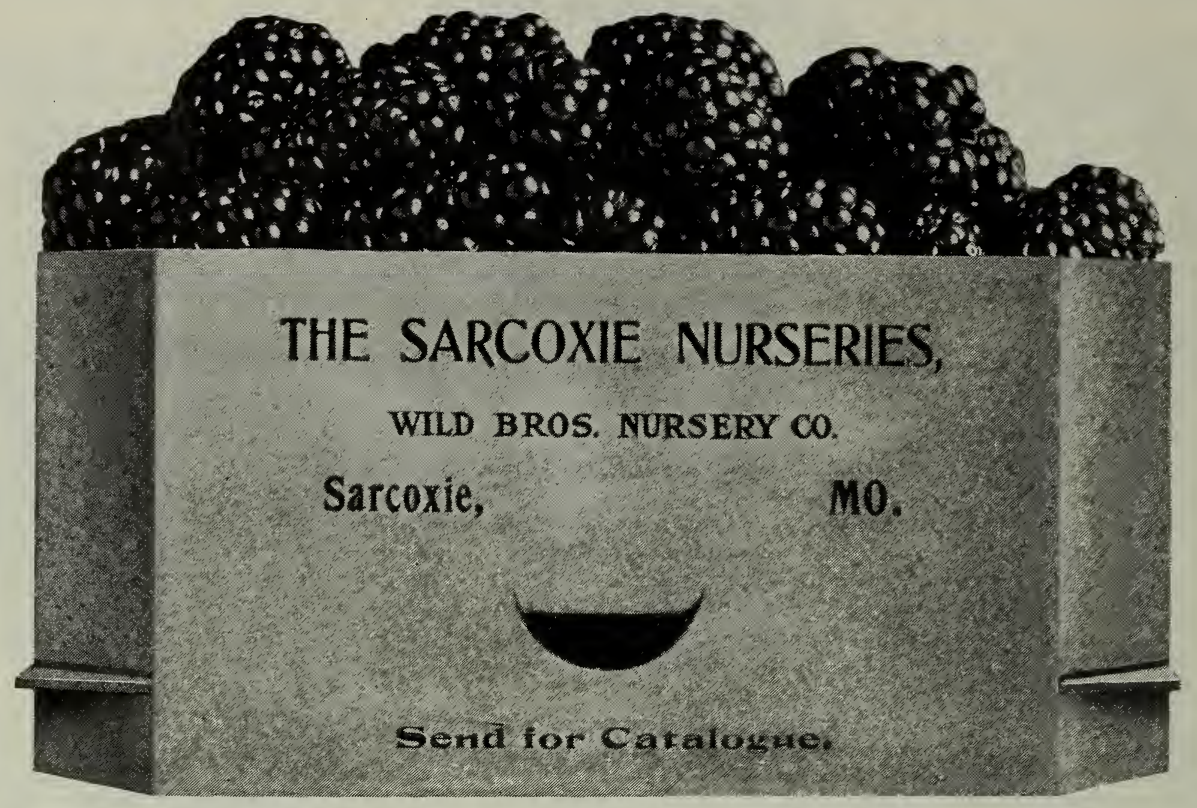

\section{Lucretia Dewberries}

$\mathrm{D}$

EWBERRY culture is justly becoming very popular and profitable. As compared with blackberries, it is less expensive, more convenient, land can be used that is wet or not fertile enough to produce blackberries and other crops, and the fruit is of such quality and ripens at a season (just between strawberries and blackberries) when it commands the highest prices.

Culture.-Prepare the ground as for corn, roll or drag well, ditch or mark out rows 4, or preferably j feet apart, and set the plants 2 feet apart, thus requiring 5,445 or 4,356 plants per acre, respectively. Cultivate well the first year, shortening in the plants during the early part of the season to make them stocky, but allow them free growth the latter part of the season.

After the first two plowings, shallow cultivation is best. Discontinue tillage in August to stop rank growth and cause the plants to ripen up a solid cane which will withstand the severest winters. The second and following years, cultivate little, more to keep out weeds and grass, as too much cultivation tends to increase growth rather than yield.

Renewing.-After your field has become a mat of vines, mow half the patch closely just after the last picking; allow the vines to dry and burn off when the wind is brisk enough for the fire to run rapidly. Harrow well, preferably after a light rain. Mark off the rows and with a diamond plow and with a cultivator work up the middles well, beginning as at first. Renewing must be done every few years, but loses you one crop, hence renew but half your field at once.

Lucretia.-The variety most largely grown for market; ripens at the close of the strawberry season, before Early Harvest; berries large, often $1 \frac{1 / 2}{2}$ inches long, sweet and luscious

throughout; unexcelled in quality by any of the blackberries; field plants $25 \mathrm{c}$ per $10, \$ 1.00$ per $100, \$ 8.00$ per 1000 . Not less than 10 sold.

\section{Raspberries}

$\mathrm{P}$ LANT 3 to 4 feet apart in rows 6 feet apart, requiring 2420 or 1815 plants per acre, respectively. Deep soll that will retain moisture in a dry season is preferable, the lighter loams for the red varieties, the heavier for the black. Allow 4 to 6 canes to grow from each plant for fruiting; pinch off the canes when $21 / 2$ to 3 feet high. Cut out all old canes when bearing season is over, as a cane bears but once. A mulch should be applied the first fall.

Fifty of a variety at 100 rate; 500 of a variety at 1000 rate; not less than 10 of a variety sold.

Cumberland.-Black cap; very large, firm, of best quality; midseason; unexcelled in hardiness and productiveness. $30 \mathrm{c}$ per $10, \$ 2.00$ per $100, \$ 15.00$ per 1000 .

Miller-Red.-Large, firm, rich flavor; early, prolific, very hardy; successful over a wide territory, $25 \mathrm{c}$ per $10, \$ 1.50$ per $100, \$ 10.00$ per 1000 .

King.-Large, early, bright scarlet, fine flavor; a strong grower, larger than Miller, and better in many respects. $30 \mathrm{c}$ per $10, \$ 1.50$ per $100, \$ 12.00$ per 1000 .

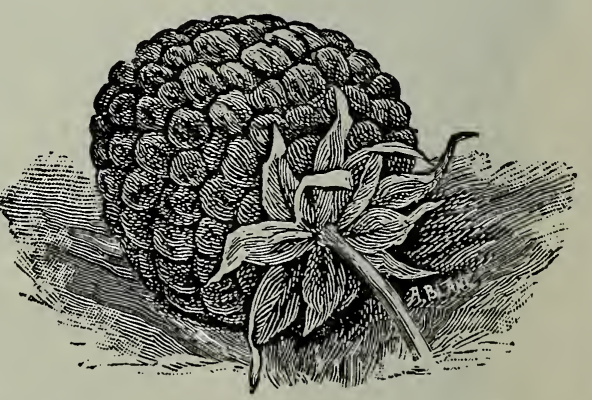




\section{Asparagus}

These asparagus are fine, large plants, strong and thrifty - the kind to plant for resultsand exceptionally good value.

The garden is incomplete without this wholesome vegetable, the earliest excepting Rhubarb. Trench 18 inches deep, mixing each layer of soil as turned over with 2 or 3 inches of well-rotted manure. Set 4 to 6 inches deep, 10 inches apart. If planted in the spring, cover at first about 3 inches, filling in as the plants grow. Cultivate well first season, subsequently in spring, again in July and August. Salt spread broadcast in early spring, about 5 pounds to the square rod, is a good fertilizer. A good top dressing of stable manure should be applied in Octoher or Norember. Do not cut the sprouts the first season. A bed once started is good for a score of years, a protitable annual crop. Not less than 10 of a variety sold. 50 of a variety at 100 rate, 500 of a variety at 1000 rate.

Conorer's Collossal.-The old standard market variety; very large, rapid growth, productive. 3 year $25 \mathrm{c}$ per $10, \$ 1.00$ per 100 .

2 year. $20 \mathrm{c}$ per $10,75 \mathrm{c}$ per $100, \$ 5.00$ per 1,000

1 year. $20 \mathrm{c}$ per 10 , 50c per $100, \$ 4.00$ per 1,000

Bonvalett's Giant.-Grown largely for the Chicago market; shoots purplish, but can be grown white by planting deeper.

3 year $30 \mathrm{c}$ per $10, \$ 1.00$ per $100, \$ 6.00$ per 1.000

Early Giant Argenteuil.-A variety of French origin noted for its earliness, productiveness, and immense stalks; good flavor.

3 year, $30 \mathrm{c}$ per $10, \$ 1.00$ per $100, \$ 6.00$ per 1.000 2 year, $20 \mathrm{c}$ per $10,80 \mathrm{c}$ per $100, \$ 5.50$ per 1,000 1 year, $20 \mathrm{c}$ per $10,60 \mathrm{c}$ per $100, \$ 4.50$ per 1.000

Palmetto. - A variety of Southern origin. large, productive, of excellent quality: popular. 1 year $20 \mathrm{c}$ per $10,60 \mathrm{c}$ per $100, \$ 4.50$ per 1,000 2 year, $25 \mathrm{c}$ per $10,75 \mathrm{c}$ per $100, \$ 5.00$ per 1,000

\section{Rhubarb (Pie Plant)}

Very easy to grow, and once set it lasts for years. Requires a deep soil and annual top dressing with manure as early as can be done. Prepare the ground the same as for asparagus, but plant 2 to $21 / 2$ feet apart in the row. The stalks can be pulled when 6 inches long and until full growth, often continuing as late as July. Do not pull any of the stalks the first year.

Mayatt's Linnaeus. Rhubarb.-Early, just before asparagus, and continues long in use; largest stalks, productive, tender, delicately flavored; the best variety for general use. $10 \mathrm{c}$ each, $60 \mathrm{c}$ per $1 \hat{\mathrm{v}}, \$ 5.00$ per $10 \hat{n}$.

\section{Horseradish}

Horseradish, Bohemian.-A new, quick growing variety, producing very large roots; productive. Is so easily grown that it should find a place in every garden; a rich moist soil is preferable. Sets, $30 \mathrm{c}$ per $10, \$ 1.50$ per 100 .

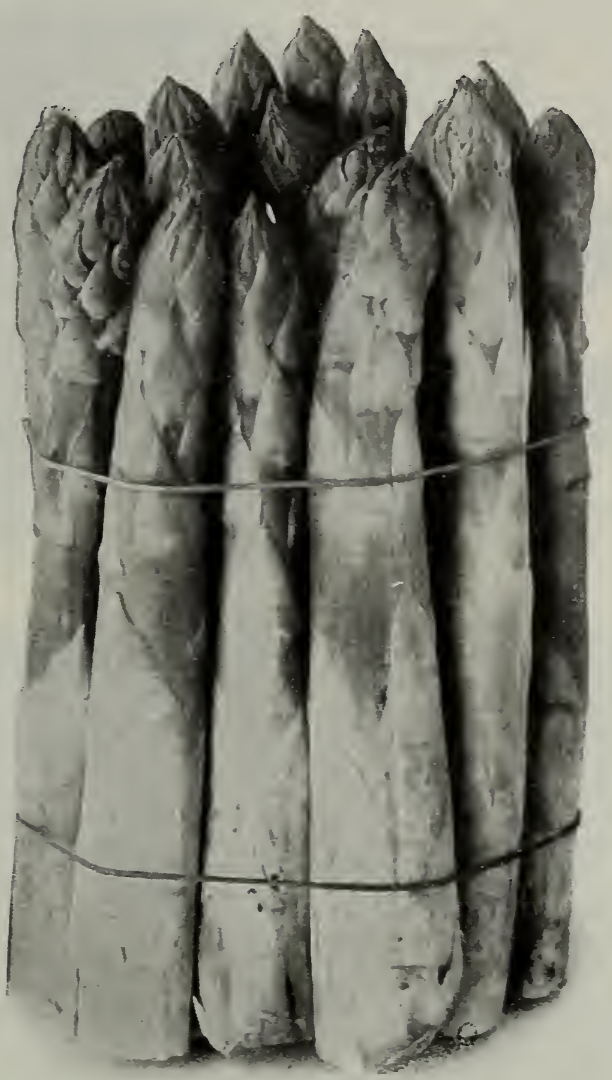

For $\$ 1.00$ to $\$ 2.00$ you can have an abundance of Asparagus each spring.

\section{Ginseng}

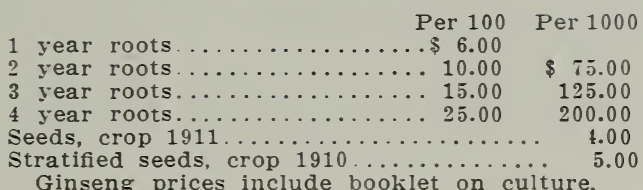

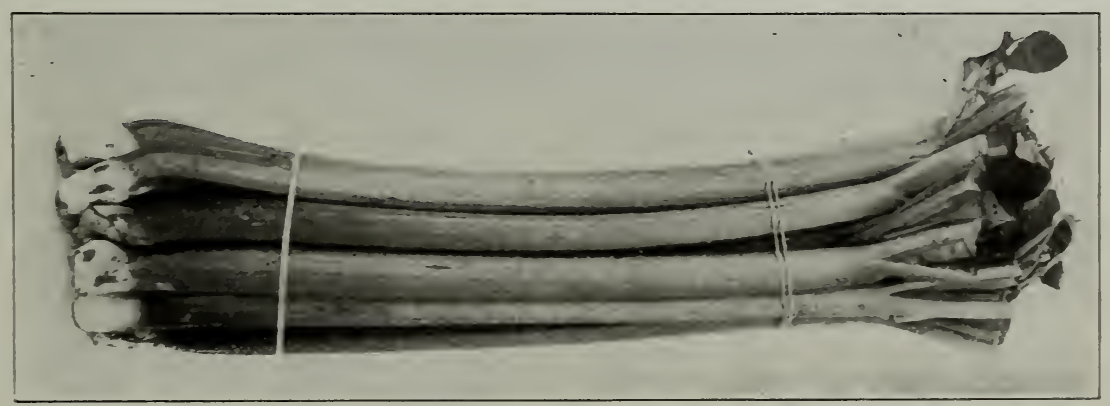

RHUBARR 


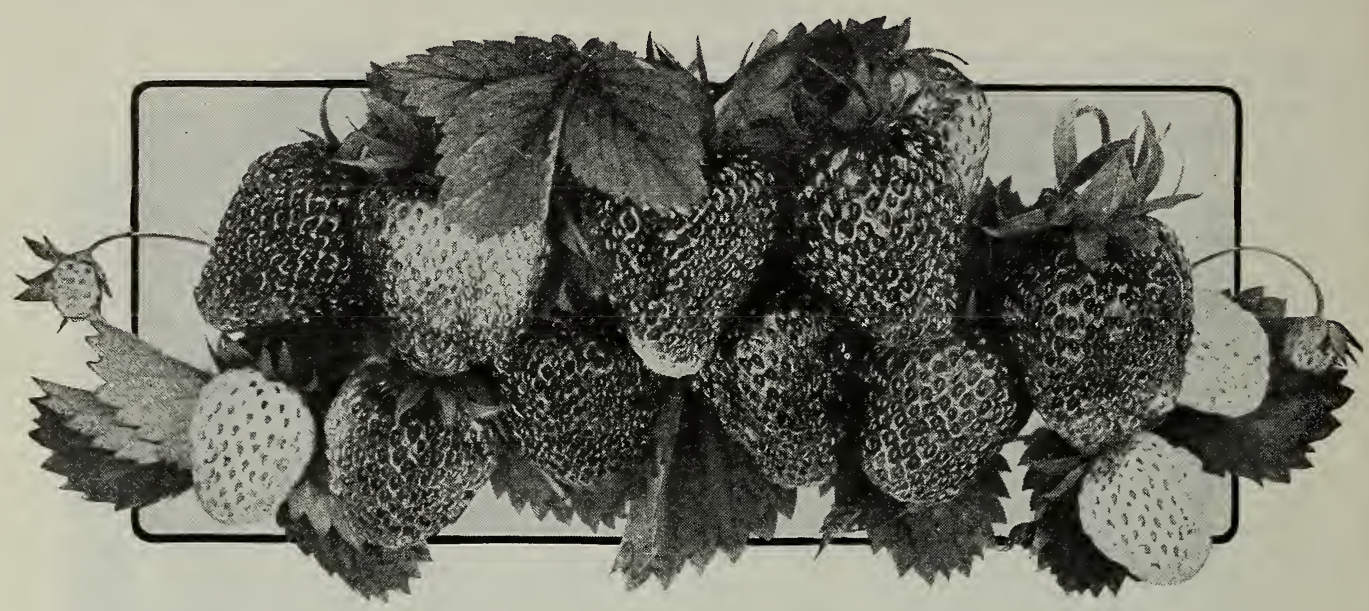

\section{Strawberries}

To other fruit gives such quick returns on the investment as strawberries. Commercially, they are one of the most profitable crops. It is just as easy to grow your strawberries for home use as your vegetables, and always have the supply ripe and perfectly fresh.

Before planting the ground should be well plowed and pulverized, about like one would prepare for corn, leveled down and firmly rolled or packed. Sticky land should not be packed, but worked down so as to be well pulverized. Set the plants just deep enough so that no part of the roots are exposed yet not deep enough to cover the crown. If planted with a dibble, the roots should be shortened to three or four inches. See that the earth is wlll firmed about the roots, as air pockets cause drying out. Give frequent and clean cultivation. In the fall after good frosts have occurred apply the mulch, rotted leaves or straw, preferably broken straw, without cheet seed in it. Very well rotted strawy manure is excellent.

There are several systems of growing. In this section the matted row is usual, allowing the plants to make runners until the desired fullness of row is obtained. Plant in rows $3 \mathrm{ft}$. $8 \mathrm{in}$. to $4 \mathrm{ft}$. apart and 2 or $3 \mathrm{ft}$. apart in the row, perhaps two feet will give best results in most cases. For garden culture the rows may be 2 feet apart. Where hill cultural is practiced, the plants are usually set about 18 inches apart in rows 30 to 36 inches apart or 2 to $2 \frac{1}{2} \mathrm{ft}$. apart each way and all runners removed as formed.

Note-When planting imperfect flowered varieties every third or fourth row must be some perfect flowered variety. $4 \times 2 \mathrm{ft}$. requires 5440 plants, $4 \times 3 \mathrm{ft}$., 3630 plants per acre.

The Sarcoxie soil and climate is particularly adapted to growing strawberries. Our plants are from new plant beds and handled in the best possible manner. They are carefully cleanea, the roots straightened, neatly tied in bunches, labeled and packed with moss.

Order early by all means; as early as possible if to be shipped by freight. Small lots and late shipments must be by express. We do not recommend freight shipments of strawberries and do not forward in that manner unless especially instructed to do so and at purchasers risk. Small lots with trees seem to carry better by freight with trees than if shipment consists entirely of plants.

Plants by Mail. The weight of plants varies with the season and varieties so it is impossible to fix upon an amount that will always be exact. If wanted by mail add $10 \mathrm{c}$ per doz., $25 \mathrm{c}$ per 100 .

I $F$ Not less than 50 of a variety at the 100 rate, nor less than 500 of a variety at the 1000 rate.

Aroma (Perfect flowered.)-Very large, glossy red; productive; midseason to late; a favorite shipper; has largely supplanted Gandy in many sections. $20 \mathrm{c}$ doz., $50 \mathrm{c}$ per $100, \$ 3.50$ per 1000 .

Bubach (Imperfect flowered.)-Very large, bright red, waxy, conical; midseason; productive, $25 \mathrm{c}$ doz., $60 \mathrm{c}$ per 100 , $\$ 5.00$ per 1000 .

Clyde (Perfect flowered.)-Large, prolific, medium early. $25 \mathrm{c}$ doz., $60 \mathrm{c}$ per 100.

Columbia (Imperfect flowered.)-Originated by Mr. Henry N. Wild, crossing Warfield with Gandy; in season between Aroma and Gandy; large to very large, attractive light scarlet; very productive. $25 \mathrm{c} \mathrm{doz.,} 60 \mathrm{c}$ per $100, \$ 4.00$ per 1000 .

Early Ozark (Perfect flowered.)-An improved Excelsior; large, productive; berries almost round, bright red, very firru, a gnnत shipper. $25 \mathrm{c}$ doz., $60 \mathrm{c}$ per $100, \$ 4.00$ per 1,000 .
Evening Star (Perfect flowered.)-Large, late, fairly productive. $35 \mathrm{c}$ doz., $80 \mathrm{c}$ per 100 .

Florella (Perfect flowered.)-Large to very large, crimson all over; good flavor; early, prolific. $25 \mathrm{c}$ doz., $60 \mathrm{c}$ per $100, \$ 4.00$ per 1000 .

Gandy (Perfect flowered.)-Very large, very late; bright red; firm, a good shipper; best on new ground. $30 \mathrm{c}$ doz., $80 \mathrm{c}$ per 100.

Haverland (Imperfect flowered.)-Large, long bright to light crimson; productive; mid-season to late; widely planted, succeeding on all soils. $25 \mathrm{c}$ doz., $60 \mathrm{c}$ per $100, \$ 4.00$ per 1000 .

King Edward (Perfect flowered.)-Large, bright red, good qualitý; mid-season; productive. $30 \mathrm{c}$ per doz., $80 \mathrm{c}$ per $100, \$ 5.00$ per 1000

Klondike (Perfect flowered.)-Medium early, dark red, good size well retained during season. $20 \mathrm{c}$ doz., $50 \mathrm{c}$ per $100, \$ 3.00$ per 1000 . 
Lady Thompson (Perfect flowered.)-Uniform medium size, light to bright red; second early in ripening. $25 \mathrm{c}$ doz., $60 \mathrm{c}$ per $100, \$ 4.00$ per 1000

Michel (Perfect flowered.)-Noted for earliness and prolific plant making; good pollenizer. $20 \mathrm{c}$ doz., $50 \mathrm{c}$ per $100, \$ 3.00$ per 1000 .

Senator Dunlap (Perfect flowered.)-Medium to large, glossy, deep red; resembles Trarfield, same season; a good shipper; giving general satisfaction. $20 \mathrm{c}$ doz., $50 \mathrm{c}$ per $100, \$ 3.00$ per 1000 .
Sons' Prolific (Perfect flowered.)-Claimed by the introducers to be superior to Aroma in plant growth, productiveness, firmness and color, brilliant red, of fine color, a few days earlier and continuing later. $25 \mathrm{c}$ doz. $60 \mathrm{c}$ per 100 $\$ 4.00$ per 1000 .

Texas (Perfect flowered.)-Large, very early. 'ossy crimson, almost round; prolific; a good shipper; resembles Excelsior, larger. $20 \mathrm{c}$ doz., $50 \mathrm{c}$ per $100, \$ 3.50$ per 1000 .

Warfield (Imperfect flowered.)-Medium to large, dark red; mid-season; productive; high quality, a leading market and best canning berry. $20 \mathrm{c}$ doz., $50 \mathrm{c}$ per $100, \$ 3.50$ per 1000 .

\section{Hardy Evergreens}

DERGREENS produce an effect obtainable in no other way, and are now appreciated every4. where as indispensable for variety and effect. Besides their recognized value as speoimen trees on the lawn, for screens, hedges, and shelter from winter's winds, the taller growing varieties form ideal backgrounds for the showy flowering shrubs and trees of spring, the berries of autumn, the bright twigs of winter, or the light green, silver or golden growths of the smaller evergreens, Beautiful effects are obtained by planting in masses varieties that contrast finely in color, form and foliage, such as the Pines, Spruces, Arborvitaes, Junipers and Biotas, the lower growing ones toward the front.

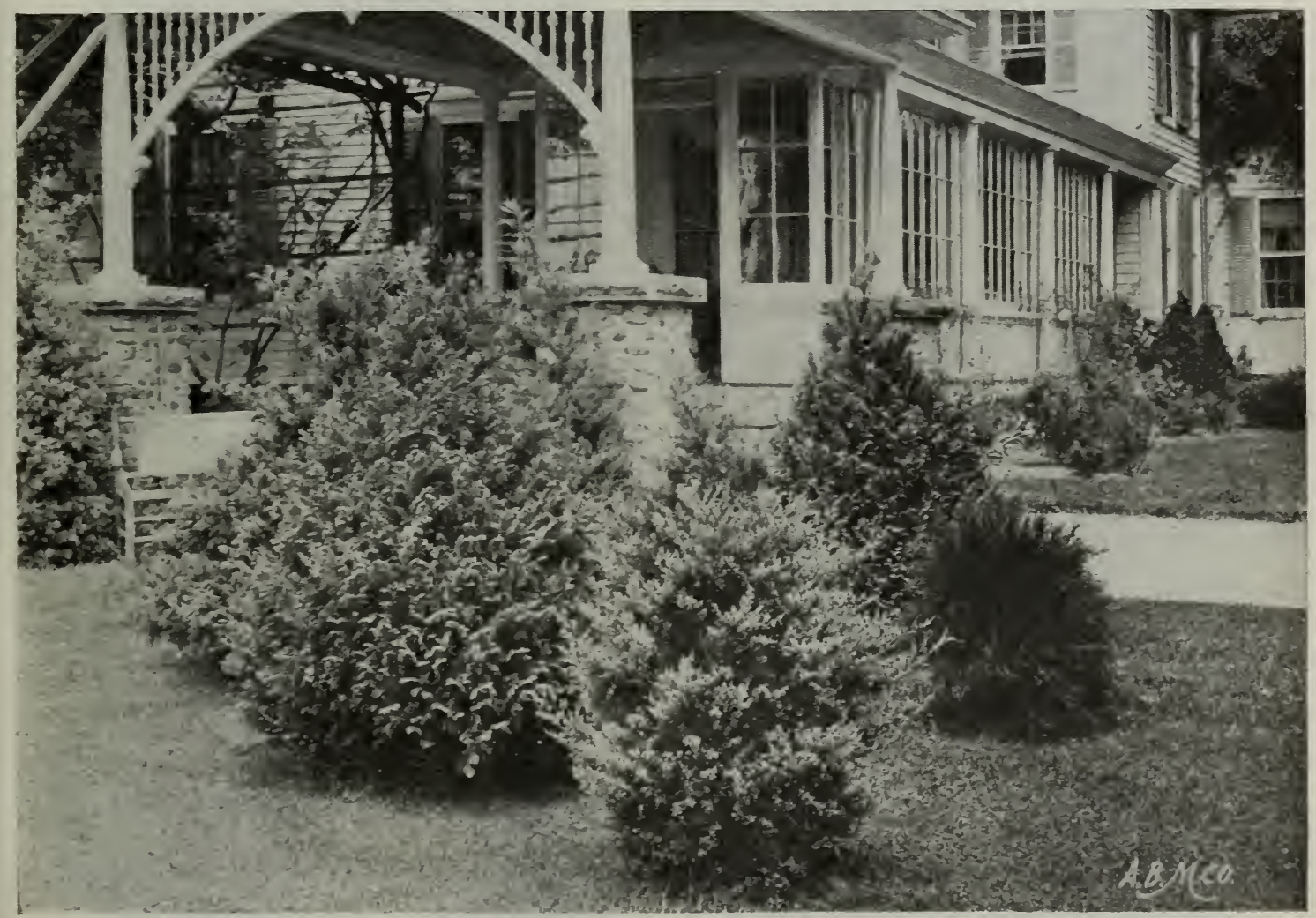

The Feathery, Golden Tipped Foliage of Retinispora Plumosa Aurea is Novel and Pleasing.

When transplanting evergreens, care must be taken that the roots are not exposed to the air longer than necessary, for their sap being resinous, if allowed to harden will not revive. Make sure that the earth is well firmed about the roots, no openings or air spaces being left, and keep the top soil slightly stirred about the tree for the first two years.

Our evergreens have been several times transplanted to secure an abundance of fibrous roots. We take great pains in handling them. When dug the roots are protected from exposure as much as possible and they are taken to our specially constructed brick building and packed under cover in a moist atmosphere.

At these prices the roots will be carefully packed in damp moss and hay. If wanted dug with a ball of earth sewed in burlap, add the following to prices quoted, to cover the cost of such: $1 \frac{1}{2}$ to $2 \mathrm{ft}$. or under, $10 \mathrm{c}$ each; $\$ 1.00$ per $10 ; 2$ to $3 \mathrm{ft}$, $15 \mathrm{c}$ each; $\$ 1.20$ per $10 ; 3$ to $4 \mathrm{ft}$., $20 \mathrm{c}$ each; $\$ 1.50$ per $10 ; 4$ to $5 \mathrm{ft} ., 25 \mathrm{c}$ each; $\$ 2.00$ per 10 ; and specify "balled and burlaped."

IF Five of a variety will be furnished at 10 rate, less at each rate; 50 of a variety at 100 rate. 


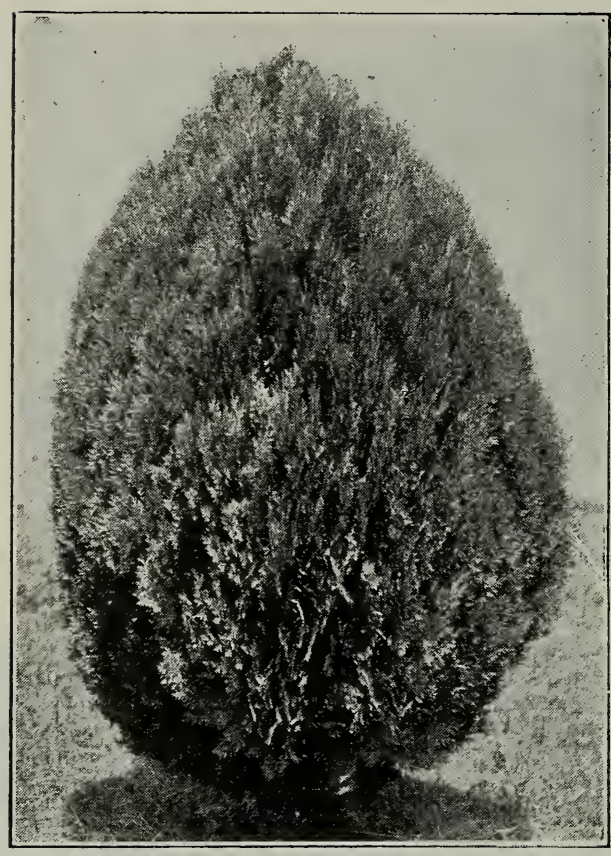

CHINESE GOLDEN DWARF ARBORVITAE.

A Perfect Gem for large or small grounds.

Arborvitae, Chinese Golden Dwarf (Biota aurea nana.)-The most popular of the Biotas. In winter the foliage is a beautiful bright green, in summer intense gold suffused with green. Of very dwarf, compact habit, the hardiest of its class, and unexcelled for garden or cemetry use; very effective for window boxes and tubs. Without a doubt the best of the dwarf golden arborvitaes, and rapidly gaining. in popularity.

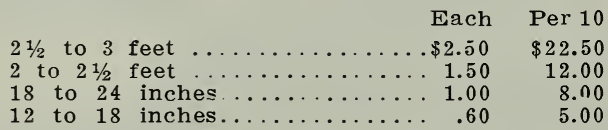

Arborvitae, Chinese Golden (Biota aurea conspicua).-A most beautiful tree; foliage intense gold suffused with green; of compact, erect, symmetrical habit; very desirable.

\begin{tabular}{|c|c|c|}
\hline 4 to 5 feet & Each & Per 10 \\
\hline $21 / 2$ to 3 feet. & $\begin{array}{r}\$ 5.00 \\
1.75\end{array}$ & $\$ 15.00$ \\
\hline 2 to $2 \frac{1}{2}$ feet & 1.25 & 10.00 \\
\hline 18 to 24 inch & .75 & 6.0 \\
\hline
\end{tabular}

Arborvitae, American.-Of upright growth, especially beautiful when young. Foliage bright green assuming bronze tints in winter. Very desirable for single specimens, groups and hedges.

5 to 6 feet $\ldots \ldots \ldots \ldots \$ 1.00 \quad \begin{gathered}\text { Each } \\ \$ 8.00\end{gathered}$

4 to 5 feet $\ldots \ldots \ldots \ldots \ldots, .75 \quad 6.00 \quad \$ 40.00$

Arborvitae, Pyramidal.-A compact and nar-
rowly pyramidal tree, with short branches densely covered with bright green foliage; very formal and attractive: in form an almost perfect column. Illustrated page 18 .

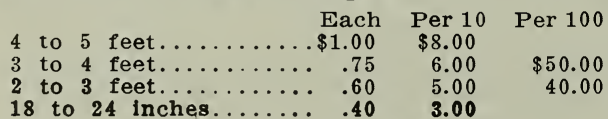

Arborvitae, Golden American, or Douglas. A tree of upright growth, especially beautiful when young; foliage bright green with very beautiful golden tipped branches.

4 to 5 feet $\ldots \ldots \ldots \ldots \ldots \ldots \ldots \ldots 1.00$ each

Arborvitae, Siberian.-A small, extremely hardy tree, becoming broadly conical with age; very dense, dark green foliage, bluish green below, its color well retained during winter; grows compact and shapely without shearing, yet endures it well, hence admirably adapted for hedges; an excellent lawn tree.

$\begin{array}{lrrrrr}3 \text { to } 4 \text { feet. } \ldots \ldots \ldots \ldots \ldots & \begin{array}{l}\text { Each } \\ 21.00\end{array} & \begin{array}{r}\text { Per } 10 \\ \$ 7.50\end{array} & \text { Per } 100 \\ 2 \text { to } 3 \text { feet } \ldots \ldots \ldots \ldots \ldots & .75 & 6.00 & \$ 50.00 \\ 18 \text { to } 24 \text { in. } \ldots \ldots \ldots \ldots & .50 & 4.00 & 30.00 \\ 12 \text { to } 18 \text { in. } \ldots \ldots \ldots \ldots & .40 & 3.50 & 25.00\end{array}$

Arborvitae, Woodward Globe.-A low, compact form with deep green foliage, assuming bronze tints in winter. A symmetrical globe in outline and of very striking appearance as individual specimens on lawns, in formal gardens and in window boxes or tubbed on porches.

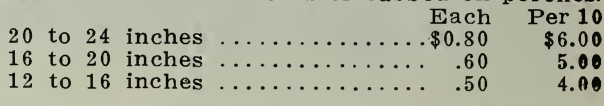

Cedar, Red.-Dense green or bronze green foliage; hardy, flourishing in almost any soil or climate. The well-known cedar found throughout the Central, Western and Southern States.

$$
\begin{aligned}
& 6 \text { to } 8 \text { feet } \ldots \ldots \ldots \ldots \ldots \ldots \ldots 1.25 \quad \begin{array}{l}
\text { Each } \\
\$ 10.00
\end{array}
\end{aligned}
$$

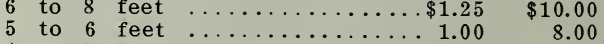

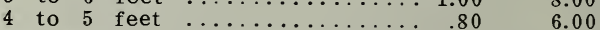

Cypress, Blue Lawson.-A tall graceful tree with fern-like foliage of a most pronounced metallic blue tint. Drooping in form; very beautiful and desirable.

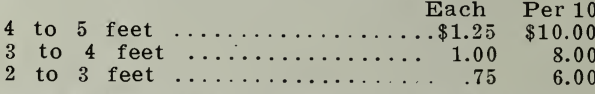

Plume-like Japan Cypress (Retinispora plumosa.) - A rapid growing variety with fine, feathery or plume-like foliage of a beautiful soft green; may be rendered dense by pruning; one of the most popular.

$$
\begin{aligned}
& 3 \text { to } 4 \text { feet Each Per } 10 \\
& 21 / 2 \text { to } 3 \text { feet } \ldots \ldots \ldots \ldots \ldots \ldots \ldots . \$ 1.25 \quad \$ 12.00
\end{aligned}
$$

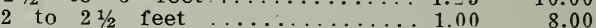

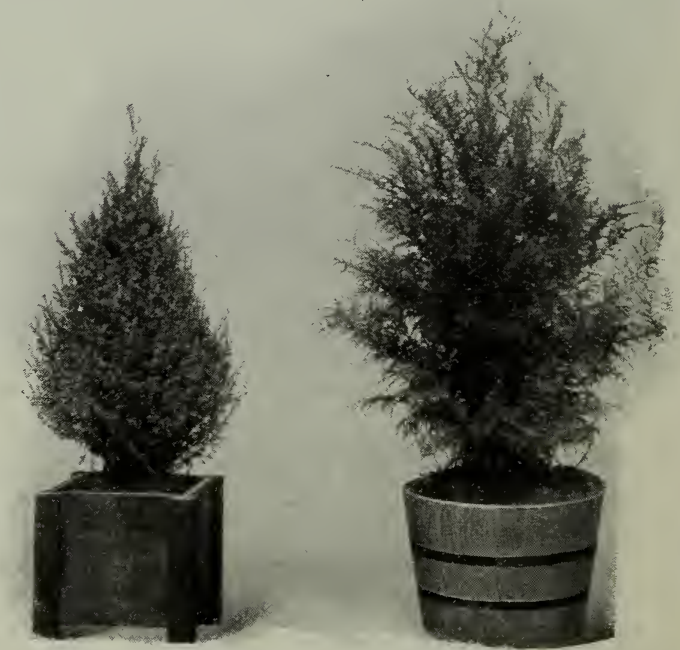

IRISH JUNIPER, Excellent as a Tubbed Specimen.
PLUME-LIKE JAPAN CYPRESS. 


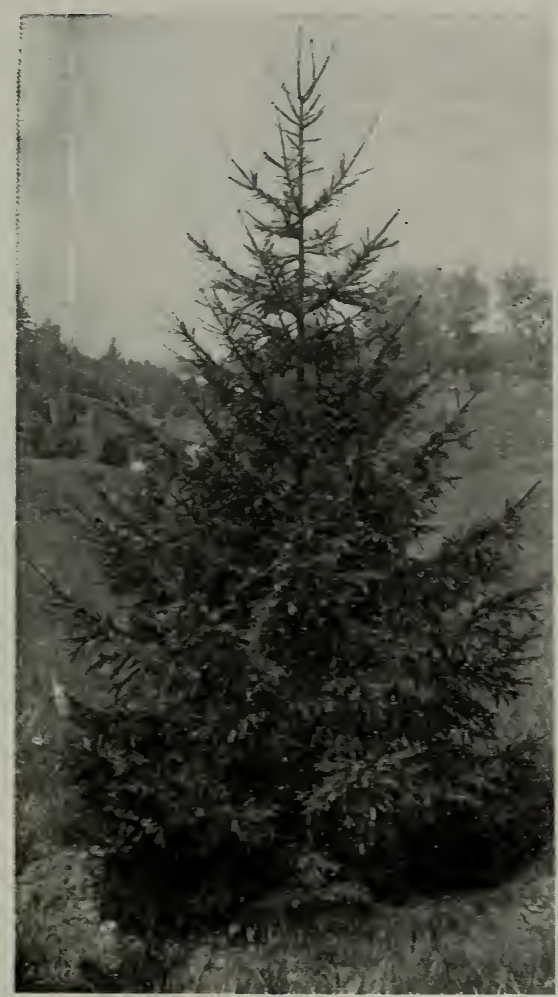

NORIVAY SPRUCE

Golden Japan Cypress (Retinispora plumosa aurea.) - A variety of the above, especially attractive in early summer when the young growth has the brightest golden hue.

$\mathrm{Each}$

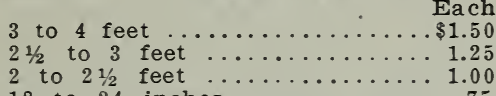

Per 10

$\$ 12.00$

10.00

8.00

18 to 24 inches ............ 75

6.00

Sawara Cypress (Retinispora pisifera.)-A Japanese evergreen of great hardiness and vigorous growth, forming a large tree of loose, open habit, but may be kept dense by shearing; foliage feathery, bright green; branches somewhat pendulous; one of the best Retinisporas for the Central States.

Each Per 10

E... $\$ 1.50 \$ 12.00$

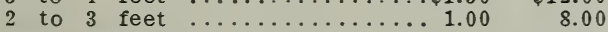

Pine, Austrian.-A robust, hardy, spreading tree adapted to various uses. Leaves 4 to 6 inches long, very dark green, in pairs. Rapid in growth when established.

Each Per 10

4 to $j$ feet $\ldots \ldots \ldots \ldots \ldots \ldots \$ 1.00$

3 to 4 feet $\ldots \ldots \ldots \ldots \ldots \ldots \ldots, .75 \quad \$ 6.00$

2 to 3 feet ....

Pine, Japanese Red (P. densiflora.) - A rapid growing ornamental tree, often very picturesque when older with its spreading, irregular head leaves in pairs, bright bluish-green, $2 \frac{1 / 4}{4}$ to inches long. . . . . . . . . . . $\$ 1.50$

6 to 8 feet ........... \$1.50 \$12.00

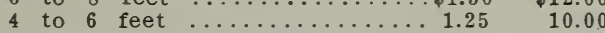

Savin Juniper.-Thickly branched, low and spreading; habit variable; very dense, dark green foliage. A favorite for many uses, especially for rock gardens and window boxes.

Each Per 10

18 to 24 inch, spread

$\$ 0.75$

$\$ 6.00$
Irish Juniper.-A densely erect and slender columnar form with numerous upright branches closely surrounding the body; finely cut, glaucus green foliage. Quick growing. Formal and striking in outline and very effective in landscape or Italian gardening and when tubbed.

These Juniper are exceptionally well grown. They have been transplanted several times to secure an abundance of roots, and sheared several times so they are compact and beautifully shaped.

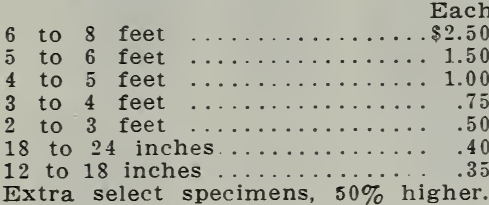

Per 10

$\$ 12.50$ 8.00 6.00

4.00

Extra select specimens, $50 \%$ higher.

Pine, Bull (P. ponderosa.) - Perhaps the largest pine; branches stout, spreading, forming a conical, narrow crown, leaves in threes, 6 to 10 in. long, dark green. 2 to 3 feet, $50 \mathrm{c}$ each.

Pine, Red or Norway.-A tall tree with stout horizontal branches. Leaves 4 to 6 inches long, flexible in pairs, dark green and lustrous. Very valuable. especially in landscape work. For richness, fullness, and vigor of foliage, it is hard to surpass.

6 to 8 feet ............... $\$ 2.00$ each

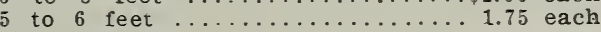

Pine, Scotch.-A tall tree with horizontal or sometimes drooping branches and dense rigid foliage of bluish-green; in pairs; $1 \frac{1 / 2}{2}$ to 3 in. iong. Broadly pyramidal, with rounded top with age. 5 to 6 feet $\ldots \ldots \ldots \ldots \ldots \ldots \$ 1.00 \quad \$ 8.00$

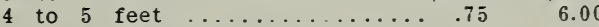

3 to 4 feet $\ldots \ldots \ldots \ldots \ldots \ldots \ldots .65 \quad 4.00$

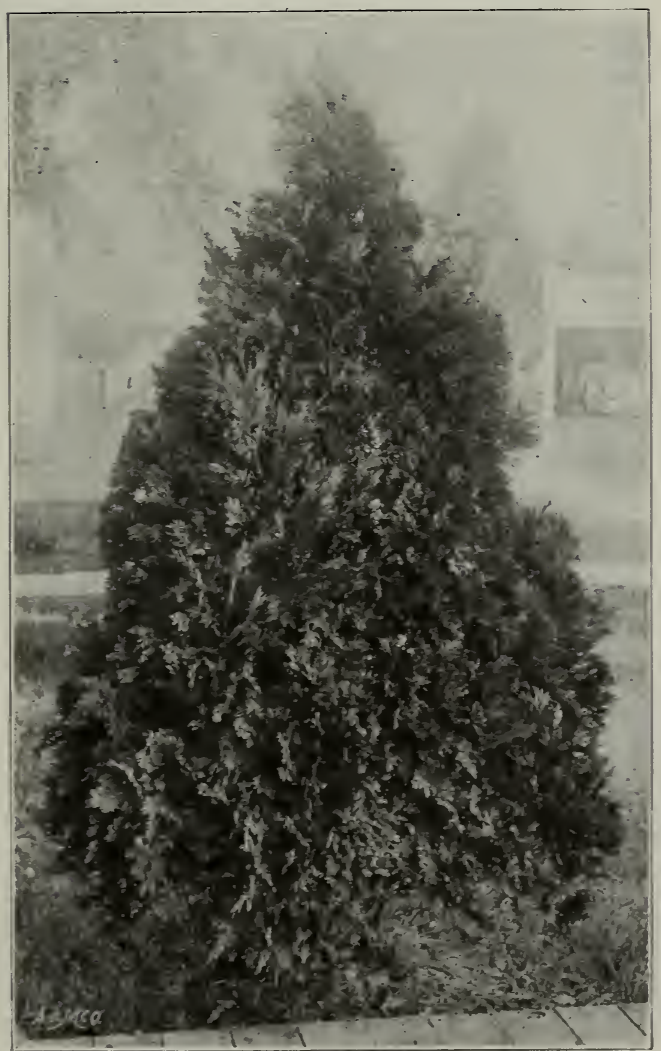

AMERICAN ARBORVITAE (page 14. ) 


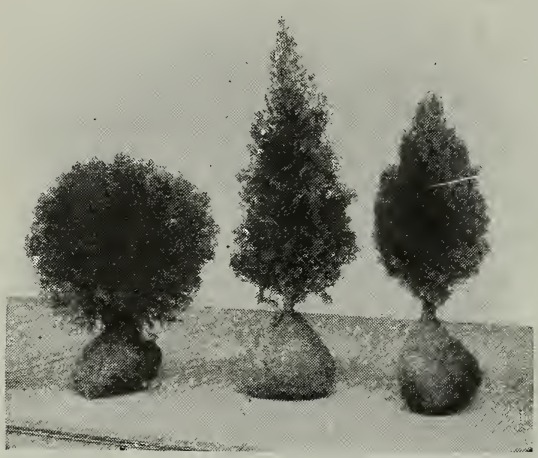

TREES "BALLED AND BURLAPED."

Pyramidal Arborvitae (Center), Woodward Globe Arborvitae (left,) Chinese Golden Dwarf Arborvitae (right.)

Pine, White.-A tall, stately tree with regular whorls of horizontal branches, forming a symmetrical, pyramidal crown; soft, bluishgreen leaves in 5 's, 2 to 4 or $3 \frac{1 / 2}{2}$ to 5 inches long. The most beautiful of our native pines.

2 to $21 / 2$ feet $\ldots \ldots \ldots \ldots \ldots \ldots \$ 0.60 \quad \begin{array}{r}\text { Each } \\ \text { Per } 10\end{array}$
Redwood.-A gigantic tree growing naturally on the crast ranges of California.

Each Per 10

6 to 8 feet $\ldots \ldots \ldots \ldots \ldots \ldots \$ 1.50 \quad \$ 12.00$

Retinispora.-See Cypress, page 16 .

Spruce, Black Hills.-Similar to Norway, withstanding cold and drought much better.

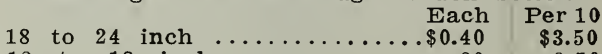

12 to 18 inch............... $130 \quad \begin{array}{r}\$ 3.50 \\ 2.50\end{array}$

Spruce, Colorado Blue.-Very richly colored foliage of a silvery blue sheen. Its form and striking appearance make it unquestionably the finest lawn tree extant. Very hardy.

3 to 4 feet, select color ........ $\$ 4.00$ each

2 to 3 feet .................. 3.50 each

Spruce, Colorado.-Green type.

Each Per 10

18 to 24 inches $\ldots \ldots \ldots \ldots \ldots \ldots \$ 0.60 \quad \$ 5.00$

12 to 18 inches ............... $.50 \quad 4.00$

Spruce, Norway.-The most widely planted spruce. Tall and picturesque with spreading, usually pendulous branches. Extensively used for ornament, screens and windbreaks.

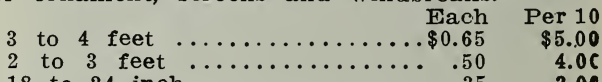

18 to 24 inch .................... 35

Spruce, Koster's Blue.-Grafted from the true blue type of the Koster"s Spruce.

3 to 4 feet.................... $\$ 6.00$ each

2 to 3 feet................. 5.00 each

\section{Broad-Leaved Evergreen Trees and Shrubs}

$\mathrm{T}$

HESE beautiful trees and plants are quite as necessary to finish planting effect as many classes more extensively planted. No garden or landscape is complete without them and many such would be greatly enhanced by their more extensive use, more noticeably in winter. A northern exposure should be selected as a planting site to prevent or moderate the direct rays of the sun. If such a situation is not at hand, partial shade is satisfactory and under either of these conditions greener foliage with more luster is produced. A cool, moist soil, though well drained, is best, and a slight covering of forest leaves will keep the roots nearer the proper temperature.

Tree Box (Buxus arborescens.)-A small tree or shrub with small, glossy green foliage thickly covering the many short branches, and possessing a peculiar fragrance. Always seen in English gardening.

20 Each Per 10

20 to 24 in., bushy .........\$1.50 $\$ 12.50$

18 to 20 in., bushy .......... $1.00 \quad 9.00$

12 to 15 in., medium bushy.... .50 4.00

6 to 8 in. for lining out hedges, $10 \mathrm{c}$ each, $70 \mathrm{c}$ per 10., $\$ 5.00$ per 100 .

Long Leaved Box (Buxus longifolia.)Spreading in growth with foliage unusually long for boxwood.

12 Each Per 10 Per 100

med. bushy $\$ 0.40 \quad \$ 3.00$

$\$ 10.00$

Willow Leaved Box (Buxus salicifolia.)-This beautiful form of Boxwood has oval dark green leaves and possesses a clearer, darker luster than any of the nine varieties in our collection, also withstanding sunlight best. Upright in growth.

12 to 15 in., $60 \mathrm{c}$ each, $\$ 5.00$ per 10 .

6 to 8 in., for lining out hedges, $15 \mathrm{c}$ each, $\$ 1.00$ per $10, \$ 8.00$ per 100 .

Dwarf Box (Buxus suffruticosa.)-A dwarf, compact evergreen shrub, extensively used for low hedges and edging; small oval leaves of a pleasing bright lustrous green.

6 to 8 inches, very bushy........30c each

Euonymus Japonicus.-An upright shrub with slightly quadrangular branches and very glossy, dark green leaves.

12 to 15 inches, slender ......\$0.20 \$1.50

Euonymus Duke of Anjon.-A form of the above, follage variegated with yellow.
Each Per 10

12 to $15 \mathrm{inch}$, slender .......\$0.25 \$1.7

Holly, American (Ilex opaca.) -A very handsome evergreen tree, familiarly known as Christmas Holly. Among its spiny green leaves are borne clusters of bright red berries. Very desirable. Should be planted in groups to produce berries. Most of the leaves should be removed from Hollies and Magnolias when transplanting.

Each Per 10

8 to 10 feet $\ldots \ldots \ldots \ldots \ldots \ldots \ldots 5.00$............. $\$ 45.00$

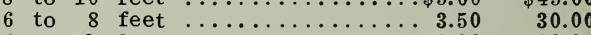

4 to 6 feet $\ldots \ldots \ldots \ldots \ldots \ldots \ldots \ldots 2.00 \quad 18.00$

3 to 4 feet $\ldots \ldots \ldots \ldots \ldots \ldots \ldots 1.25 \quad 10.00$

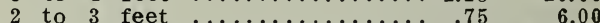

Holly, English.-A small shrub with darker green but smaller leaves than the American species. Must have partial shade and winter protection.

8 to 10 inch .............50 each

Magnolia Grandiflora (Southern Magnolia or Bull Bay.) -A stately tree of the South with large evergreen leaves, thick and glossy. Large waxy white, fragrant flowers Tender north.

2 to 3 feet ..............\$1.00 each

Thorn, Evergreen or Pyracantha.-A compact, much branched shrub of low, spreading habit; flat-topped clusters of white flowers in spring followed by scarlet berries.

inches ............... \$0.25 \$2.00

Adam's Needle (Yucca flamentosa.) - A stately plant, forming an immense tuft or cluster of long, narrow or blade-like needle-tipped leaves, from which rises a majestic flower stem 4 to 6 feet high crowned with a profusion of large, drooping, creamy-white, bell-shaped flowers. Bold and imposing in appearance. Strong plants, $15 \mathrm{c}$ each, $80 \mathrm{c}$ per 10 , sa 00 per 100 . 


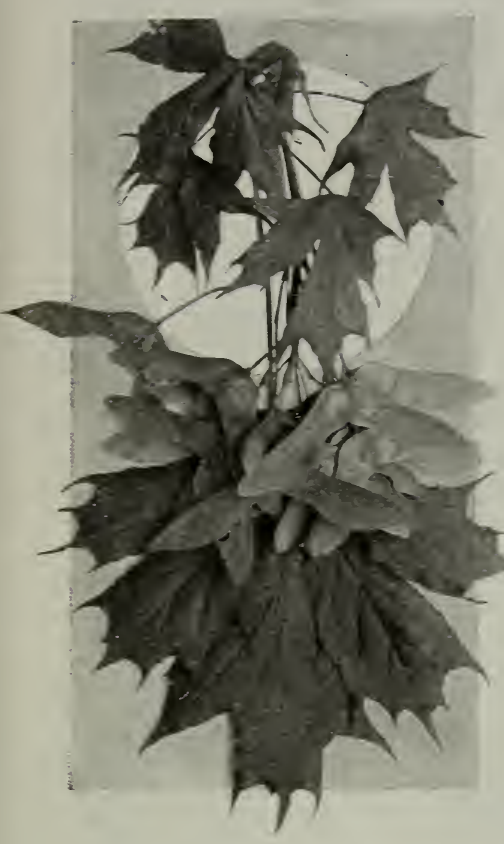

\section{Shade Trees}

$\mathrm{N}$

O landscape or lawn is complete without this group of trees, the foundation of all other plantings. The wide range in outline, habit, color tones or foliage and flowering qualities make them among the most valuable ornamentals. Nothing can be planted which will grow so well with so little care and attention as trees. The first cost is small and paid for many times over by the beauty, pleasure and satisfaction which they bring, in addition to the added value of the property.

Transplanting Hints.-To do their best, trees should have reasonably fertile soil. Such as would grow good crops is suffcient. Where they are to be set along graded streets from which the top soil has been removed or for any reason the soil is poor, a large hole should be dug and filled with rich earth such as a garden soil. If there is a dense, hard pan, it is often an advantage to loosen it up with a small charge of some slow acting high explosive, thus providing drainage and opportunity for the roots to go deeper. The truntis of large trees should be partially protected from the sun the first summer. Trim any broken roots with a sharp knife; see that the soil is well firmed. Prune, usually about one-third. Ordinarily the leader or central shoot should not be cut back severely, and it is often unnecessary at all unless to make the head more dense.

Five of a variety at the 10 rate, less at the each rate; 50 of a variety at 100 rate. Large trees above eight feet will be pruned back unless otherwise ordered. Cal. designates caliper or diameter at the ground. Larger sizes than priced herein will be quoted by mail.

Ash, Variegated.-A novel form of the Ash, dwarf in hablt and upright in growth. Foliage small, strikingly variegated green and gold. Very desirable and suited for many purposes.

5 to $6 \mathrm{ft}$., $75 \mathrm{c}$ each, $\$ 6.00$ per $10 ; 4$ to $5 \mathrm{ft}, 60 \mathrm{c}$ each, $\$ 4.00$ per $10 ; 3$ to $4 \mathrm{ft} ., 50 \mathrm{c}$ each, $\$ 3.50$ per 10 .

Birch, European White.-A beautiful tree: silvery white bark; graceful slender branches: quite erect when young, with a few years growth assuming an elegant drooping habit.

$$
\begin{array}{llll}
11 / 2 & \text { to } 21 / 2 & \text { Each } & \text { Per } 10 \\
1 & \text { to } 11 / 2 \text { in. caliper....... caliper........ } \$ 1.25 & \$ 10.00 & 8.00
\end{array}
$$

Catalpa speciosa (Western Catalpa.)-Rapidly becomes a large tree; very hardy; leaves large, dark green, heart shaped; flowers white, gotted reddish and violet, in panicles, followed by long seed pods.

Each Per 10

Elm, American White-A large and stately tree with long, graceful, drooping branches. Leaves oblong, dark green, turning pale yellow in autumn. The well known elm of our American forests, one of the best trees for street, lawn, park and landscape planting.

$$
\text { Each Per } 10 \text { Per } 100
$$

1 to $11 / 2$ inch caliper... $\$ 0.65 \$ 5.00$

6 to 8 feet ............ $40 \quad 3.00 \quad \$ 20.00$

5 to 6 feet $\ldots \ldots \ldots \ldots \ldots . .30 \quad 2.50 \quad 15.00$

4 to 5 feet $\ldots \ldots \ldots \ldots . .25 \quad 2.00 \quad 12.50$

Kentucky Coffee Tree.-A large tree with rough barked, stout twigless branches, forming a narrow round head; broad fronds of bluishgreen leaves; its seeds were roasted for coffee before and during the Revolutionary War.

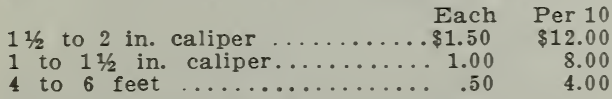

4 to 6 feet

Hickory, Shellbark. -2 in. cal., $\$ 2.00$ each.

To make the house a home the grass, trees and shrubs each have their place. Each is indispensable in the finished picture. Think of the homes you have seen, complete in architectural beauty but standing alone, and compare them mentally with the home surrounded by trees and flowers.
Linden, European or Lime Tree-A large tree with spreading branches and a symmetrical round topped crown; heart shaped, bright green

\begin{tabular}{|c|c|c|c|}
\hline \multicolumn{4}{|r|}{ Per 10} \\
\hline & caliper & $\$ 0.75$ & $\$ 6.00$ \\
\hline 4 & to 6 feet ... &.$\$ 0.40$ & 3.00 \\
\hline 3 & to 4 & . .30 & 2.50 \\
\hline
\end{tabular}
leaves fading to yellow in autumn. Fragrant creamy white flowers. Valuable for street and lawn.

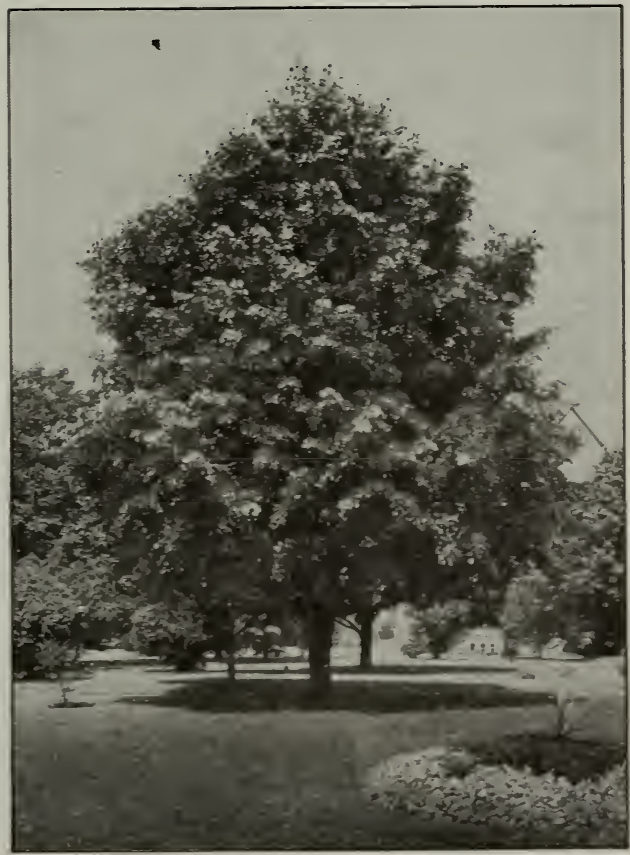

The Lindens have Fragrant Flowers. 


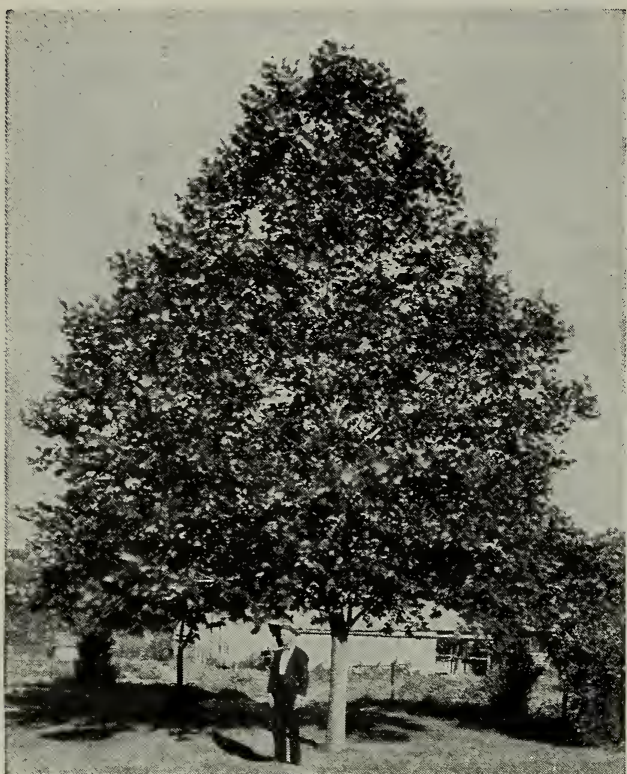

AMERICAN PLANE.

Maidenhair Tree (Ginkgo biloba, Salisburia adiantifolia.)-A fine, columnar growing tree attaining a height of 60 to 80 feet; bright, glossy green foliage, resembling Maidenhair fern in form but larger; fruit plum-like, enclosing a sweet-kerneled nut; very free from insect injury; of special value for isolated specimens to secure picturesque effects.

2 in. cal., $\$ 2.00$ each; 3 in. cal., $\$ 3.00$ each.

Magnolia Tripetela; Umbrella Magnolia.-This variety produces a very tropical effect and makes a fine showing on the lawn or large grounds. Branches irregular, leaves 16 to 24 inches long, disposed in whorls about branches; large creamy white, very fragrant flowers.

$11 / 2$ to 2 in. cal. .............. $\$ 1.50$ each 1 to $1 \frac{1 / 2}{2}$ in. cal. .................. 1.00 each

Maple, Sugar or Rock.-A very stately tree, thriving on almost any soil. Its dense symmetrical crown and beautiful foliage at once pronounce it the best of its class for lawn, street or avenue planting. Deeply rooted, allowing grass to grow freely about the trunk. Leaves three to five lobed, dark green above, pale beneath, in autumn assuming most beautlful shades of yellow, orange, and scarlet.

\begin{tabular}{|c|c|c|}
\hline & Each & Per 10 \\
\hline to 3 in. caliper & $\ldots \$ 3.00$ & $\$ 25.00$ \\
\hline 2 to $2 \frac{1}{2}$ in. caliper. & $\ldots 2.50$ & 20.00 \\
\hline $13 / 4$ to 2 in. caliper & 2.00 & 18.00 \\
\hline $1 \frac{1 / 4}{4}$ to $1 \frac{1 / 2}{}$ in. caliper & 1.25 & 10.00 \\
\hline 1 to $1 \frac{1 / 4}{\text { in }}$ caliper. & .75 & 6.50 \\
\hline 6 to 8 feet $\ldots \ldots \ldots$ & .50 & 3.50 \\
\hline 5 to 6 feet & .45 & 3.00 \\
\hline 4 to 5 feet & .35 & 2.50 \\
\hline
\end{tabular}

Larger sizes priced upon application.

Maple, Norway.-A large, handsome tree with spreading branches and a compact round head. Foliage deep green and shining.

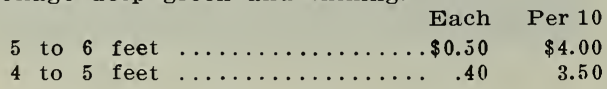

Maple, Scarlet.-A native species with fine rounded head; attractive at every season from its excellent habit, early deep red flowers before the leaves appear, bright red seed, and brilliant scarlet, autumnal foliage.

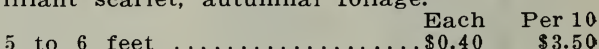

Maple, Soft, White or Silver.-Of much more rapid growth than most trees, and very effective when immediate shade is desired.

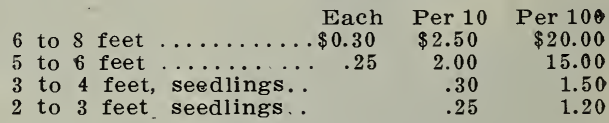

Oak, Chestnut.-A tall tree with broad open crown; leaves similar to American Chestnut, often coloring beautifully in autumn; acorn chestnut brown; makes a grand full grown lawn specimen.

2 in. cal., ................ \$2.50 each

Oak, White.-A spreading, towering species with rugged, massive trunk and branches; bark light gray; leaves highly colored red when unfolding; bright green at maturity, in autumn purple and red, falling tardily, sometimes not till spring; one of the finest oaks for lawn or park.

4 to 5 in caliper $\ldots \ldots \ldots \ldots$

4 to 4 in. caliper $\ldots \ldots \ldots \ldots \ldots \ldots \ldots \ldots \ldots \ldots+3.50$

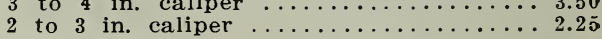

Plum, Othello.-The foliage is of the most brilliant reddish-purple, holding its color througholit the season; growth upright; fruit deep crimson, about one inch diameter.

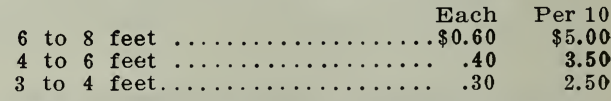

Plane Tree, American. (American Sycamore.) -A very large and lofty tree with massive branches forming a round head. In winter its whitish mottled trunk presents a striking effect; an excellent street and park tree; of very rapid growth.

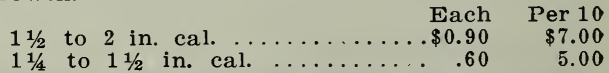

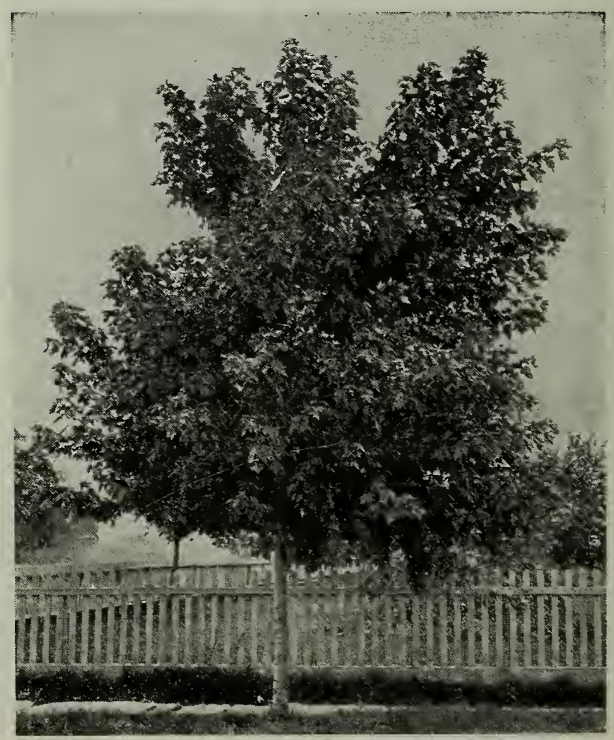

SOFT OR SILVER LEAF MAPLE 
Poplar, Norway.-The Sudden Saw Log, will no doubt supplant Carolina Poplar, which it resembles in general appearauce, but is of even more rapid growth and holds its leaves better in fall than the Carolina.

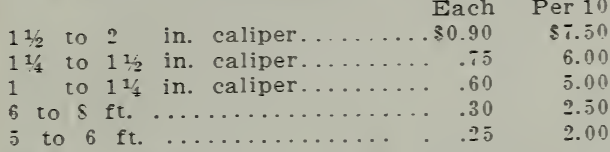

Walnut, Black. - The common variety producing the beautiful furniture wood; nut large, fine flavored. rich, hardy.

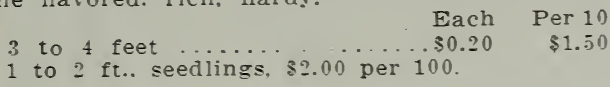

Tulip Tree (Liriodendron tulipifera.) - A magnificent native of tall pyramidal habit and rery rapid growth; leaves light green and lustrous. four lobed, pale yellow and orange in autumn. Cup shaped flowers, greenish-yellow, blotched with orange, resembling a tulip.

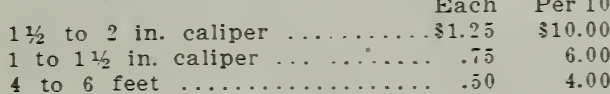

Willow, Babylonian Weeping.-A picturesque well known tree with beautiful slender and pendant branches. Its narrow bright green leaves appear in rery early spring.

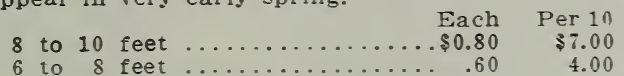

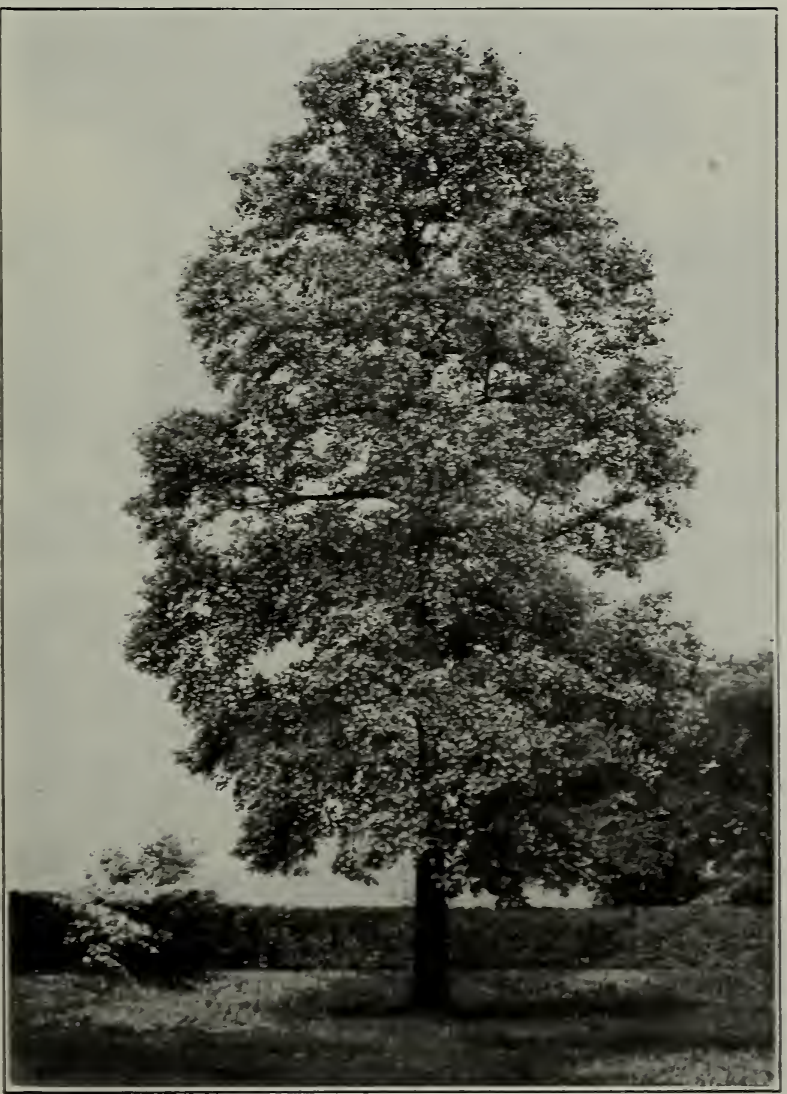

Tulip Tree is Well Named for its Flowers.

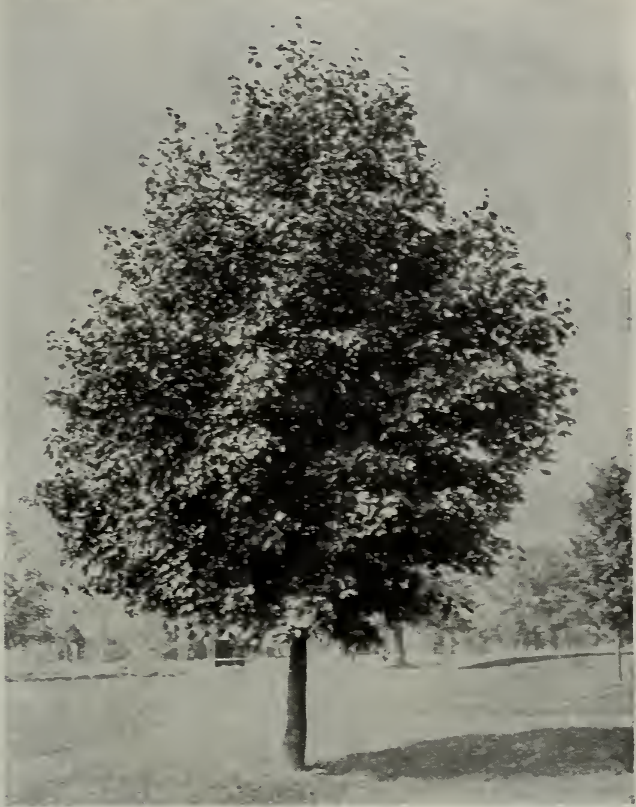

SLGAR MAPLE.

Willow, Golden Babylonian Weeping.-A distinct form of the Babylonian Weeping Willow, with bright yellow bark.

Each Per 10

4 to 6 feet.......... 50 .50 $\$ 3.00$

Willow, Laurel Leaved.-A compact small tree or large shrub. Leaves dark green and glossy, resembling the laurel, their odor when bruised resembling the Bay Tree. Fine for rrnamental planting and foliage effects.

$$
\begin{array}{rrrrrr}
5 & \text { to } 6 & \text { feet } & \ldots \ldots \ldots & \text { Each } & \text { Per } 10 \\
4 \text { to } 5 \text { feet } & \ldots \ldots \ldots & \$ 30 & \$ 3.40 \\
2.50
\end{array}
$$

\section{Ornamental Grass}

Eulalia Japonica, Variegated. Blade-like leaves are creamy white with broad maryin of bright green. In autumn the foliage is over-towered with long, perfectly shaped plumes, turning silvery at first frost. $15 \mathrm{c}$ each, $70 \mathrm{c}$ per $10, \$ 5.00$ per 100 .

Eulalia Japonica Zebrina (Zebra Grass.) - Leaves distinctly striped crosswise with large bars of white. $15 \mathrm{c}$ each, $70 \mathrm{c}$ per 10 .

Erianthus Ravennae.-A reed-like ornamental grass throwing up twenty to thirty flower stalks \& to 10 feet high when well grown. The plumes are highly valued as parlor ornaments. A rival of the gorgeous Pampas Plume (Gynerium) when in bloom. $15 \mathrm{c}$ each, $\$ 1.00$ per $10, \$ 6.00$ per 100 .

Ribbon Grass.-A low growing grass with variegated leaf blades. Suitable for hedging grass or shrub plantings or as clumps. $10 \mathrm{c}$ each: $60 \mathrm{c}$ per $10, \$ 4.00$ per 100. 


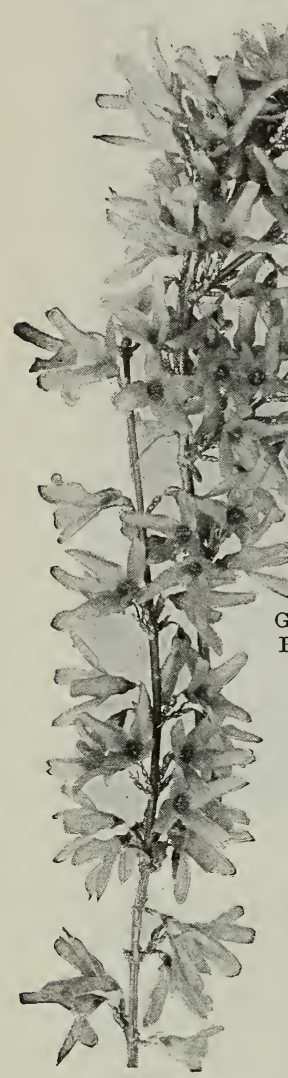

\section{Hardy Flowering Shrubs}

LOWERING shrubs make a beauti4 ful display in a year or two, giving the lawn a very attractive, finished appearance, and should be extensively used in laying out new grounds. There is hardly a lawn which their use would not improve. They appear to best advantage planted in groups, along. the boundaries or division line of properties, at the foundations of buildings, and along walks or drives. Usually mass plantings should be irregular in outline and contain more than one species. By a proper selection of say a dozen varieties, a succession of bloom may be had during the greater part of the summer. Use individual specimens freely, as a rule not too much scattered. Judicious planting may relieve the angularity of foundations, pinning the house to the ground.

As a rule shrubs require little pruning. Reduce them one-third to one-half when planting, and keep them in proper shape and size by the use of the knife or shears. Any extensive pruning should be done with GOLDEN reference to the blooming period. Varieties which flower before midBELL summer, such as Deutzia, Golden Bell, Mock Orange and Lilac, should be pruned after flowering, otherwise the quantity will be much reduced. Those flowering after mid-summer, consequently on the new wood, such as Hydrangea, should be pruned in winter or early spring.

Five of a variety at the 10 rate; less at each rate; 50 of a variety at the 100 rate.

Almond, Dwarf Double Flowering Pink.-Desirable for its profusion of flowers in double rosettes in early spring.

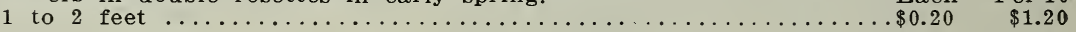

\section{Althea (Hibiscus syriacus, Rose of Sharon)}

Handsome shrubs of upright growth and valuable as single plants and for screens, hedges, etc., particularly in sections where soil and arid climate do not permit the use of other shrubs. Its somewhat bell-shaped flowers appear in late summer when few shrubs are in bloorn.

Althea Atrorubens, or double red.

Althea Banner.-Double, variegated pink and white. One of the best. Althea Double Lilac; Double, White.

Althea Jean of Arc.-Pure white, very double, the best double white.

Althea Totus Albus.-Beautiful single, pure white; dwarf; exceptionally good.

Variegated.-Conspicuous for its foliage.

Prices of Althea:

4 to 6 feet $\ldots \ldots \ldots \ldots \ldots \ldots \ldots \$ 0.40 \quad \$ 3.00$

4
3 to 4 feet $\ldots \ldots \ldots \ldots \ldots \ldots \ldots \ldots$

2 to 3 feet $\ldots \ldots \ldots \ldots \ldots \ldots . .25 \quad 2.00$

Barberry, Thunbergs (Japanese Barberry.) - Of dwarf dense spreading habit. with graceful though spiny branches and small, beautiful green leaves coloring brilliantly in autumn. Almost inconspicuous creamy-white flowers followed by scarlet berries remaining all winter. Forms a nicely shaped specimen plant and is admirably suited for low hedges, borders, or edges, enduring partial shade.

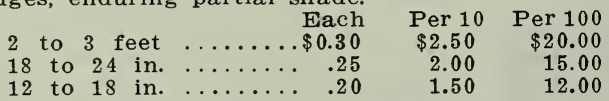

Calycanthus Floridus (Sweet-scented Shrub). - unique old garden favorite valued for its odd, double, spicily-fragrant, chocolate red flowers; twigs reddish, leaves glossy dark green.

12 to 18 inches ...............20 each

Deutzia Pride of Rochester.-A vigorous, upright shrub, bearing in early spring a profusion of dainty double, bell-shaped flowers in racemes 4 to 6 in. long; white, outer petals tinted rose; of easy culture, thriving in almost any soil not too wet.

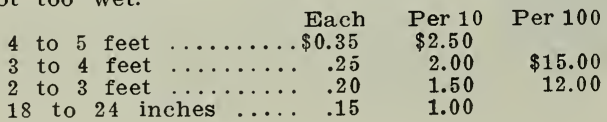

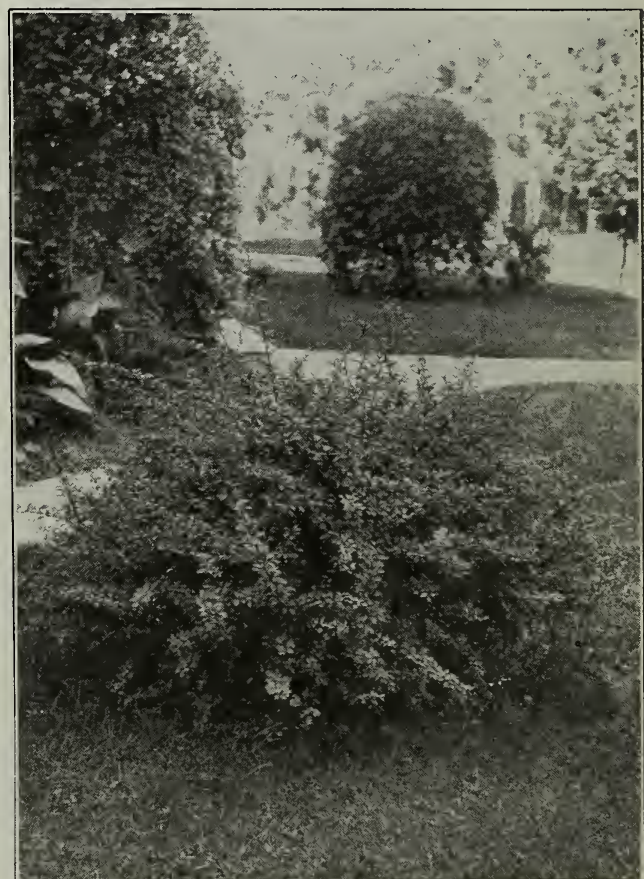

THIUNBERG'S BARBERRY forms a nicely shaped specimen shrub 


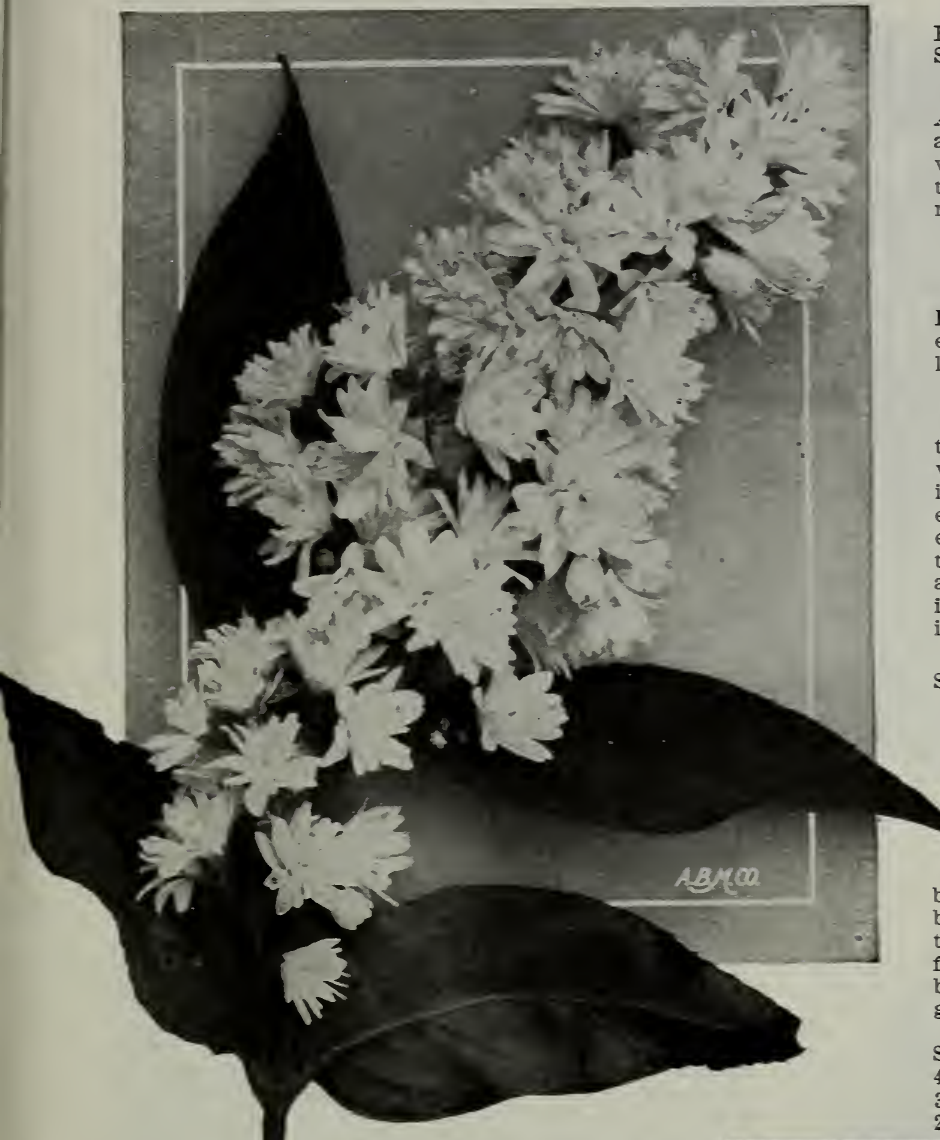

Deutzia Double Pink.-Similar to Pride of Rochester, but more color. Same price.

Deutzia Gracilis.-Slender Deutzia. A small shrub with slender, often arching branches, and single pure white flowers as delicate as Lily of the Valley, in graceful nodding racemes.

12 to 18 inches ..... Each $\begin{array}{r}\text { Per } 10 \\ \$ 0.25\end{array}$

Euonymous, European (Burning Bush.) - Its light, yellow seeds are enclosed in quaintly beautiful, fourlobed capsules, usually pink.

4 to 5 feet..........50 each

Golden Bell, Dark Green (Forsythia viridissima)-One of the most welcome sights of early spring with its mass of golden yellow flowers, even before the leaves are dereloped, it deserves a place in all collections. Erect in habit with green bark and dark green foliage; usually seen in shrubbery borders and mass planting but makes a nice specimen shrub.

Each Per 10 Per 100 Specimen plants.. $\$ 1.00 \$ 8.00$

4 to $5 \mathrm{ft} . \ldots \ldots \ldots .50 \quad 4.00 \quad \$ 30.00$

3 to $4 \mathrm{ft} . \ldots \ldots \ldots . .30 \quad 2.50 \quad 18.00$

2 to $3 \mathrm{ft} \ldots \ldots \ldots . .25 \quad 2.00 \quad 15.00$

Golden Bell, Weeping (Forsythia suspensa). - A very graceful, drooping form of the above, very free flowering, highly effective planted on banks or retaining walls where the branches droop naturally; sometimes trained up a wall 5 or 6 feet, or in front of the piazza, and its long branches allowed to sweep the ground.

Each Per 10 Per 100 Specimen plants.. $\$ 1.00 \$ 8.00$ $\begin{array}{lllllll}4 & \text { to } & 5 & \mathrm{ft} . \ldots \ldots & .50 & 4.06 & \\ 3 & \text { to } & 4 & \mathrm{ft} . \ldots \ldots & .30 & 2.50 & 18.00\end{array}$

The dainty double bellshaped flowers of the Deutzia claim attention from all.

Hydrangea Hills of Snow; or American Everblooming (Hydrangea arborescens sterilis.)-A valuable hardy shrub; white flowers turning to green instead of brown as other Hydrangeas. Blooms from June until August. Grows best in full sun; thrives in partial shade. Strong field plants, $40 \mathrm{c}$ each; $\$ 3.00$ per 10 .

Hydrangea Paniculata Grandiflora.-This most popular Hydrangea grows to a height of 7 to 10 feet; flowers in great pyramidal panicles, white on opening, assuming rose and bronze tints on exposed sides. Blooms profusely in August and September when few other shrubs are in bloom. One of the finest shrubs.

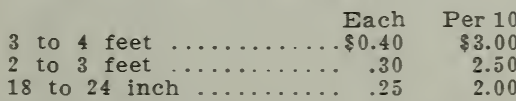

Lilac, Common Purple.-The best known and still one of the farorite $\mathrm{Li}$ lacs, admired by all for its fragrance, its earliness, and its wondrous wealth of dark purple flowers in clusters: wherever planted it seems appropriate very effective in groups; vigorous, enduring neglect.

$\begin{array}{lllll} & \text { Each } & \text { Per } 10 & \text { Per } 100 \\ 2 \text { to } \$ \text { feet } & \ldots . . \$ 0.30 & \$ 2.50 & \end{array}$

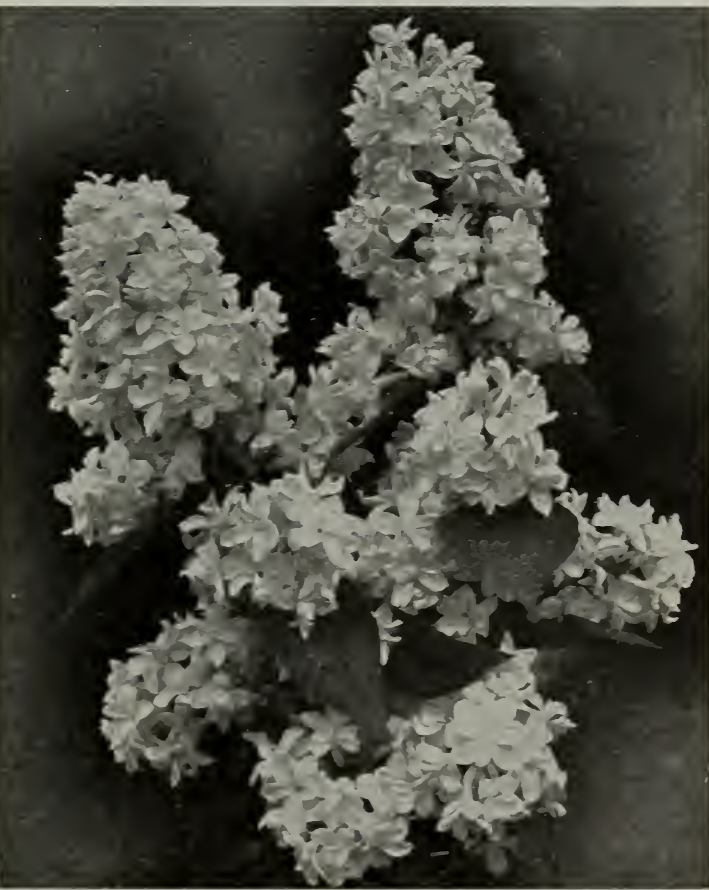

The Fragrant Lllac will always be a Favorlte. 


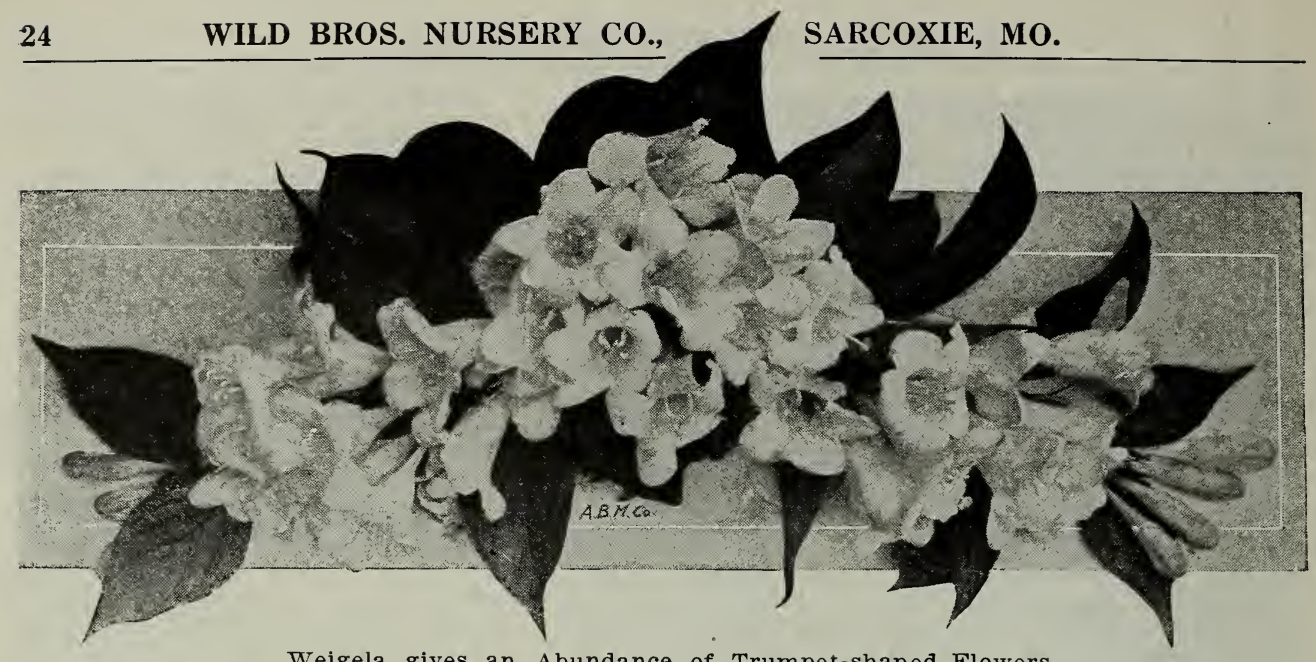

Weigela gives an Abundance of Trumpet-shaped Flowers.

Lilac, White. -1 to 2 feet, $25 \mathrm{c}$ each.

Lilac Persian.-Pale lilac flowers in broad panicles in late spring; slender branches, rich green foliage; medium height.

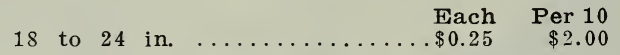

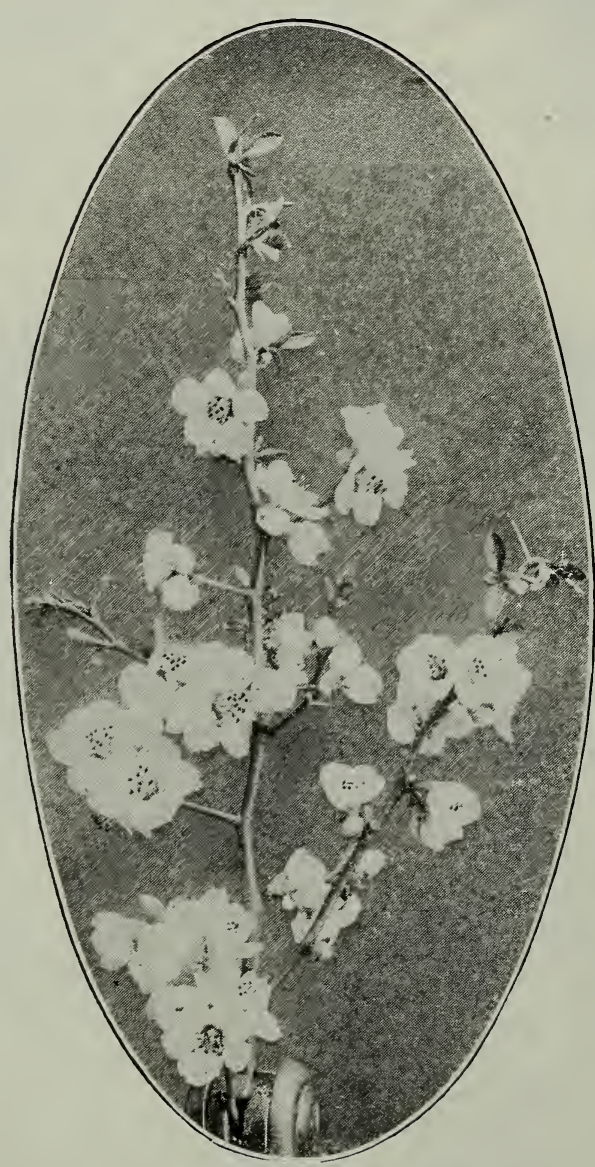

WHITE JAPAN QUINCE.

Blooms before the leaves are developed.

\section{Mock Orange}

\section{(Philadelphus, Syringa}

The name is almost a sufficient description. Its flowers appear in profusion in late spring or early summer, adding grace and beauty to any garden or shrubbery border. Vigorous, thriving in almost any well drained soil.

Sweet Scented Mock Orange (P. coronärius.) -Rather tall; creamy white, very fragrant flowers in profusion. Showy and desirable; should be in all colections. No. 5 to $6 \mathrm{ft}$. size.

Double Flowered Mock Orange. ( $P$. dianthiflorus.) - A variety with double white flowers of good size and substance. 2 to $3 \mathrm{ft}$., only.

Large Flowered Mock Orange ( $P$. grandiflorus.) - A tall variety with very large, pure white, very showy flowers, later than $P$. coronarius. We can supply all sizes of this.

Each Per 10

5 to 6 feet $\ldots \ldots \ldots \ldots \ldots \ldots \$ \ldots .75$ \$6.00

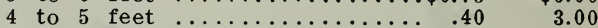

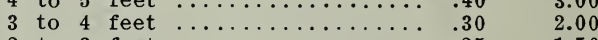

2 to 3 feet $\ldots \ldots \ldots \ldots \ldots \ldots \ldots .25 \quad 1.50$

Jasmine, Yellow.-A slender shrub, needing the support of a trellis or wall; its small starry yellow flowers open during the mild days of spring. Old-fashloned favorite. $25 \mathrm{c}$ each.

Jasmine, White.-More tender than above and should have a sheltered position. $25 \mathrm{c}$ each.

Pearl Bush (Exochorda grandiflora.) - A Chinese shrub with slender branches. Very attractive in early spring with its fragrant terminal racemes of pearl-like buds and starry white flowers. Best massed with other shrubs.

4 Each Per 10

4 to 5 feet $\ldots \ldots \ldots \ldots \ldots \ldots \ldots \ldots \$ 0.50 \quad \$ 4.00$

3 to 4 feet $\ldots \ldots \ldots \ldots \ldots \ldots \ldots \ldots \ldots .30 \quad 2.50$

Privet, California.-This most popular hedge plant is of free, upright growth with dark, glossy green leaves. Nearly evergreen in the Southern States. Also used for single specimens for terrace, hall or porch decoration. For hedges set in trenches, the smaller sizes 8 inches apart, the larger 8 , or 10 to 12 inches. Prune to within 4 to 6 inches of the ground severely the next one or two seasons, after that to maintain the height and shape desired.

Each Per 10 Per 100

Quince, White Flowered Japan (Pyrus japonica niavalis.) - A hardy shrub with handsome single white flowers in very early spring before the leaves are developed; fragrant greenishyellow fruit. The branches are spiny, foliage pleasing, making a valuable shrub for informal hedges or single specimens.

3 to $4 \mathrm{ft}$. $35 \mathrm{c}$ each; 2 to $3 \mathrm{ft}$, $25 \mathrm{c}$ each. 
Smoke Tree. (Purple Fringe.)-A large shrub or small tree with purple flowers in loose panicles, becoming plumose, giving it a smoky appearance in early summer.

Large plants, $50 \mathrm{c}$ each.

Snowball.-An oldtime garden favorite, very impressive in early summer with its abundance of pure white flowers in showy balls.

3 to 4 feet, $35 \mathrm{c}$ each, $\$ 3.00$ per 10 ; 2 to 3 feet, $25 \mathrm{c}$ each, $\$ 2.00$ per 10 .

Snowberry, White Fruited. - Branches slender bending under the weight of the white berries, very conspicuous after the leaves have f a lle n. Strong plants, $30 \mathrm{c}$ each.

Snowberry, R ed Fruited.-15c each.

\section{Spirea}

Few shrubs lend themselves to every situation or condition as $\pi$ ell as spireas, showy, free flowering shrubs of easiest culture and covering a considerable blooming period from spring into summer. They are valuable for garden, lawn and landscape planting, being graceful, compact and hardy, preferring sunny situations.

Spirea Billardi.-Upright in growth, flowers bright pink in dense, finger-like panicles, 5-8 inches long in summer, and from time to time till fall if cut back liberally as they fade.

Spirea Fontenaysii alba.--Tpright in growth with willow-like leaves and white flowers in finger-like panicles in summer.

Spirea Prunifolia Double, or Bridal Wreath.Tall and graceful with small, double, showy, white flowers, clustered thickly along the slender branches in early spring; foliage, shining, dark green, turning orange in Autumn.

Spirea Reevesiana Double.-Very similar to Van Houttei except the flowers are double,

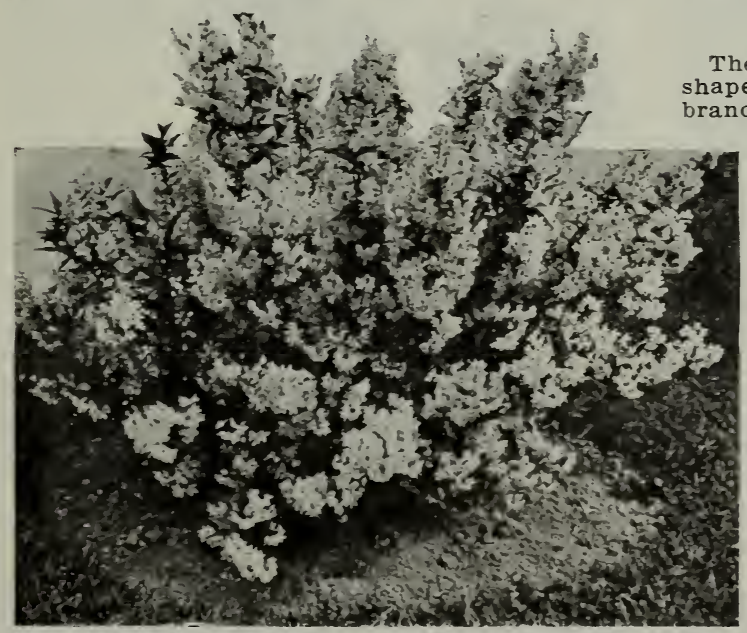

The Flowers of Deutzia Gracilis are as Delicate as Lily of the Valley habit is more upright though arching gracefully, and blooms later, the two making excellent companion shrubs.

Spirea Tan Houttei; Tan Houtte's Bridal Wreath.-Beautiful at any season when in bloom in early to late spring its dense drifts of white flower wreaths on gracefully arching branches are singularly graceful. The foliage is a pleasing dark green, bluish beneath, coloring beautifully in Autumn. It makes an excellent informal hedge and a fine specimen plant. With all a grand shrub and indispensable for lawn and landscape planting.

Prices of above Spirea.

$\begin{array}{llrr}\text { Specimen plants } \ldots \ldots & \begin{array}{l}\text { Each } \\ \text { Spen }\end{array} & \text { Per } 10 & \text { Per } 100 \\ 4 \text { to } 5 \text { feet } \ldots \ldots \ldots \ldots & .50 & \$ 4.00 & \$ 25.00 \\ 3 \text { to } 4 \text { feet } \ldots \ldots \ldots \ldots & .30 & 2.50 & 15.00 \\ 2 \text { to } 3 \text { feet } \ldots \ldots \ldots \ldots & .25 & 2.00 & 12.00 \\ 18 \text { to } 24 \text { inches } \ldots \ldots & .20 & 1.50 & 10.00\end{array}$

Spirea Anthony Waterer.-Dark crimson flowers, borne in large heads in great profusion all summer. Dwarf, 20c each.

\section{Weigela (Diervilla)}

The Weigela, with its quantity of trumpethaped flowers clustered thickly along the ranches in late spring, is showy as a specimen plant and almost a necessity in mass planting and shrubbery borders. Of variable habit, thriving in any common garden soil, preferably moist.

Weigela Amabilis.-A large, showy, pink or rose-flowered form of vigorous growth.

Weigela Desboisi.-Flowers deep rose. Weigela Hendersoni.-Flowers light rose.

Weigela Rosea.-A rose flowered variety blooming early and profusely; excellent.

Weigela Variegated.-Leaves green, margined with yellow; flowers blushwhite.

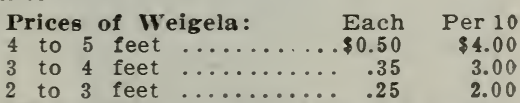
2 to 3 feet 3 ........... 25 r 2.00 or shrub honeysuckle bearing abundant. white, fragrant flowers, followed by masses of red berries. $25 \mathrm{c}$ each. 


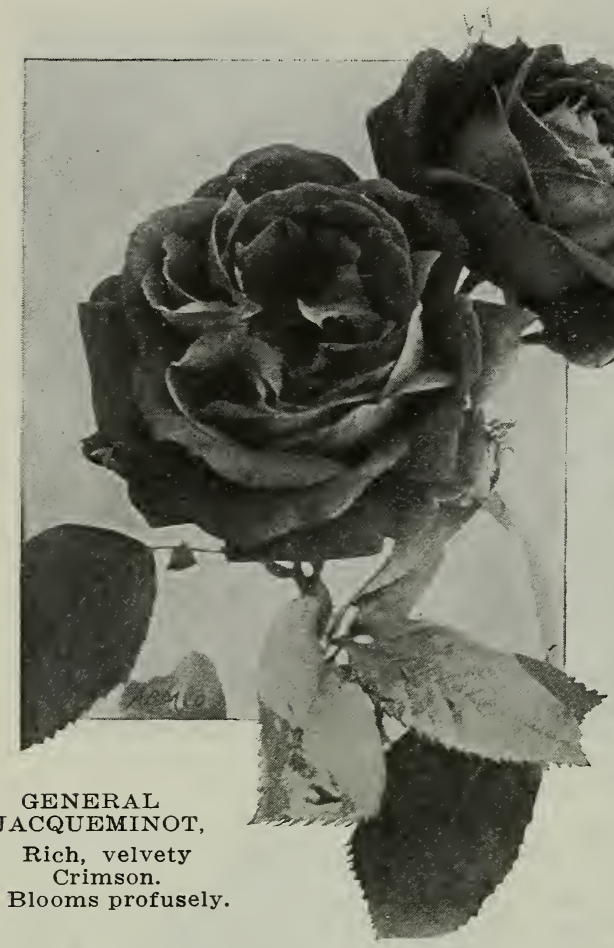

\section{Hardy Hybrid Perpetual Roses}

PRICES.-Except as noted, 25c each; $\$ 2.00$ per $10 ; 5$ of a variety at the 10 rate; less at each rate.

American Beauty.-Large; deep pink shaded with carmine; delicious fragrance. $40 \mathrm{c}$ each; $\$ 3.00$ per 10 .

Caroline Marniesse.-Blooms medium size, pure white slightly tinted pink; a constant and profuse bloomer; very hardy and especially adapted to cemetery and border planting.

Clio.-Flesh color, shaded at the center with rosy-pink, large, fine globular form, blooms freely; vigorous growth; handsome foliage.

Coquette Des Alps. - Large, well formed, pure white, sometimes faintly tinged pale blush; full and free in flower, delicious fragrance.

Frau Karl Druschki (Snow Queen, White American Beauty.) - Splendid long pointed buds and magnificent snow-white blooms, full, deep and double. The best white hybrid perpetual. Always in bloom. $40 \mathrm{c}$ each, $\$ 3.00$ per 10 .

Gen. Jacqueminot.-Rich, brilliant, velvety crimson; fragrant; fine buds and flowers; one of the best for open ground; blooms profusely.

Madam Masson.-Large, full clear bright rose flowers, highly perfumed; noted for its constant and profuse blooming.

Madame Plantier.-Among all pure white roses this is one of the hardiest, and especially good for cemetery planting; strong, vigorous, forming handsome, upright bushes, and blooming very profusely in early summer when roses are particularly welcome; fragrant. $25 \mathrm{c}$ each, 3 for $65 \mathrm{c}, \$ 2.00$ per 10 .

Paul Neyron.-Deep, shining rose; very large, full and double; finely scented; a good strong grower with nice stems, very few thorns; blooms continuously.

\section{Roses}

THESE most beautiful of flowers are everywhere prized for their fragrance, beauty of form and color, and long blooming period. Anyone who has a small piece of ground and sunshine can grow roses, especially the Ramblers and Hybrid Perpetuals. Roses may be grown in any soil that will produce fair grain or vegetables, though for best results a rich, deep loam is required. The ground should be well spaded to a depth of two feet or more, and may be enriched with thoroughly rotted manure or finely ground bone. The situation should be sheltered but not shaded and should be well drained. The Hybrid Perpetuals, while not as constant bloomers as the Teas, flower profusely, re perfectly hardy and particularly suited for openround planting, quickly growing into large, vigorus bushes. The Everblooming Tea and Noisette lass require some winter protection by covering evergreen boughs, coarse straw, leaves or other at do not cover before frost or so as to exlude air and light. Annual pruning in early spring, and a little cutting back after the first blooms of the Hybrid Perpetual and Tea class, will produce more wers with better stems.

Note-Our roses are not the small plants offered n dollar collections sent by mail, but have been grown in the open field. The illustration of White aman Cochet is from a photo of the blooms proaced the summer before they are sold to you. Our plants are suitable for general planting and will average 8 to 20 inches in height according to class and habit of growth of the variety. All kinds do not produce the same growth in two years. We can upply mailing size field grown plants (smaller than hose sent by express) of a number of varieties, at the ach rate postpaid.

Prince Camille de Rohan.-Large, fragrant flowers; deep, rich, velvety crimson, shading maroon. A handsome variety.

Ulrich Brunner--Rich glowing crimson, elegantly flamed with scarlet; of fine form and substance; fragrant; vigorous; profuse bloomer.

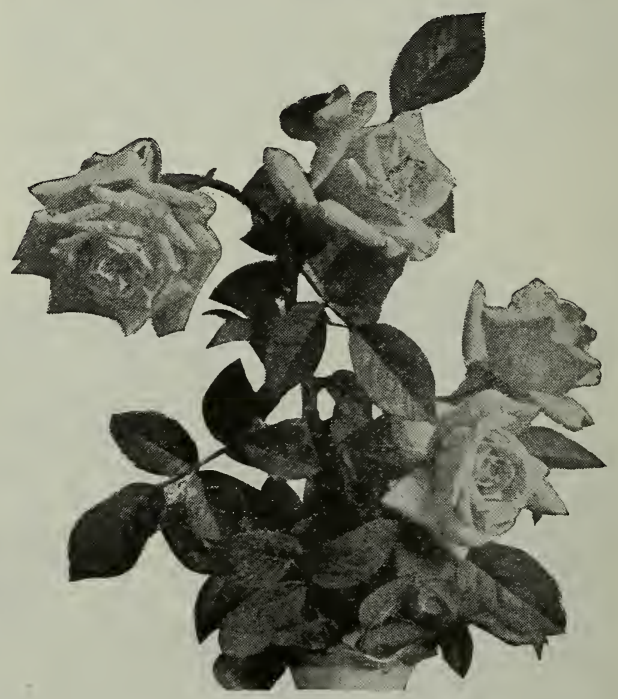

WHITE MAMAN COCHET.

As they bloom the year before they are sold to you. 


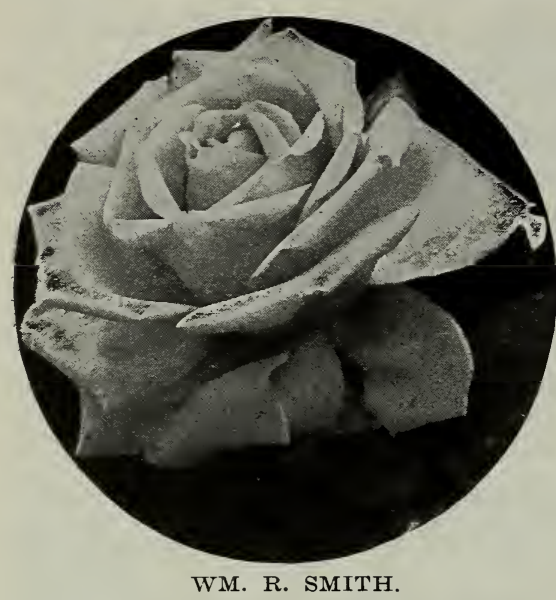

WM. R. SMITH.

Helen Good (T.) $\rightarrow$ Delicate yellow suffused with pink, each petal edged deeper; chaste and beautiful. The color with its large size and exquisite form make it unquestionably a grand tea rose. $35 \mathrm{c}$ each; $\$ 3.00$ per 10 .

Helen Gould (H. T.)-Sometimes termed the Red Maman Cochet. Flowers full, perfectly double, buds long and pointed, color warm, rosy crimson; incessant bloomer; fine bedder. $30 \mathrm{c}$ each; $\$ 2.50$ per 10 .

Kaiserin Augusta Victoria (H. T.)-Pointed buds, large flowers, delicate creamy white, delightfully fragrant.

Mlle. Francisca Kruger (T.) - Variable with the season from coppery-yellow to rose, always beautiful; pointed buds; vigorous grower, free bloomer; one of the best bedding Tea Roses.

Pink Maman Cochet (T.)-Buds large, full, elegantly pointed, opening perfectly double; deep rosy-pink, the inner side of the petals silvery rose; fragrant. There is no finer pink rose.

White Maman Cochet (T.)-Large and full, beautiful snowy-white, sometimes tinged with a suggestion o1 blush adding to its attractiveness; tea scented; an excellent bedding rose.

Wm. R. Smith (T.) - Creamy white with soft blendings of salmon-pink, rose pink and blush tints; long pointed buds; a good grower and producing immense

Yellow Soupert (Mosella) (H. Pol.)-Very double flowers in clusters, chrome-yellow, shading to creamy white at the edge of the petals. quantities of beautifully formed flowers; sold as Maiden's Blush and Jeanette Heller by some. $40 \mathrm{c}$ each; $\$ 3.50$ per 10 .

\section{Desirable Hardy Vines}

LIMBING vines are as necessary to the comfort and beauty of a home as trees and shrubs. They tone down the stiff, bold angles of new buildings, furnish shade and flowers over porches and trellises, and heighten the charm of rock, precipice, tree trunk or ruin. When planted near the house where the soil is very dry from the protection of the building or drainage by foundation, the soil should be well enriched and watered until they become thoroughly established.

Five of a variety at 10 rate, less at each rate.

Akebia quinata.-A Japanese vine of great merit with pleasing, dainty, five fingered foliage; of rapid growth, odd flowers, purplish-blue to rosy-purple, with three cup shaped petals. $25 \mathrm{c}$ each, $\$ 2.00$ per 10 .

American Ivy, Virginia Creeper. (Ampelopsis quinquefolia.)of rapid growth with five fingered leaves, graceful and most adaptable for natural effects, clinging to trees and walls. $15 \mathrm{c}$ each, $\$ 1.00$ per 10 .

Ampelopsis Veitchii, (Boston Ivy.) - 25c each, $\$ 2.00$ per 10 .

Ampelopsis Engelmanni.-A variety of Arnerican Ivy, a high climbing vine clinging by means of disc-bearing tendrils. In Autumn the leaves fade with gorgeous tone of red and scarlet: berries blue, in panicles; a very rapid grower, excellent for covering walls, verandas or trunks of trees. $25 \mathrm{c}$ each; $\$ 2.00$ per 10 .

Bittersweet, Climbing - A high climbing American vine with broad bright green leaves and orange-yellow seed-covering which
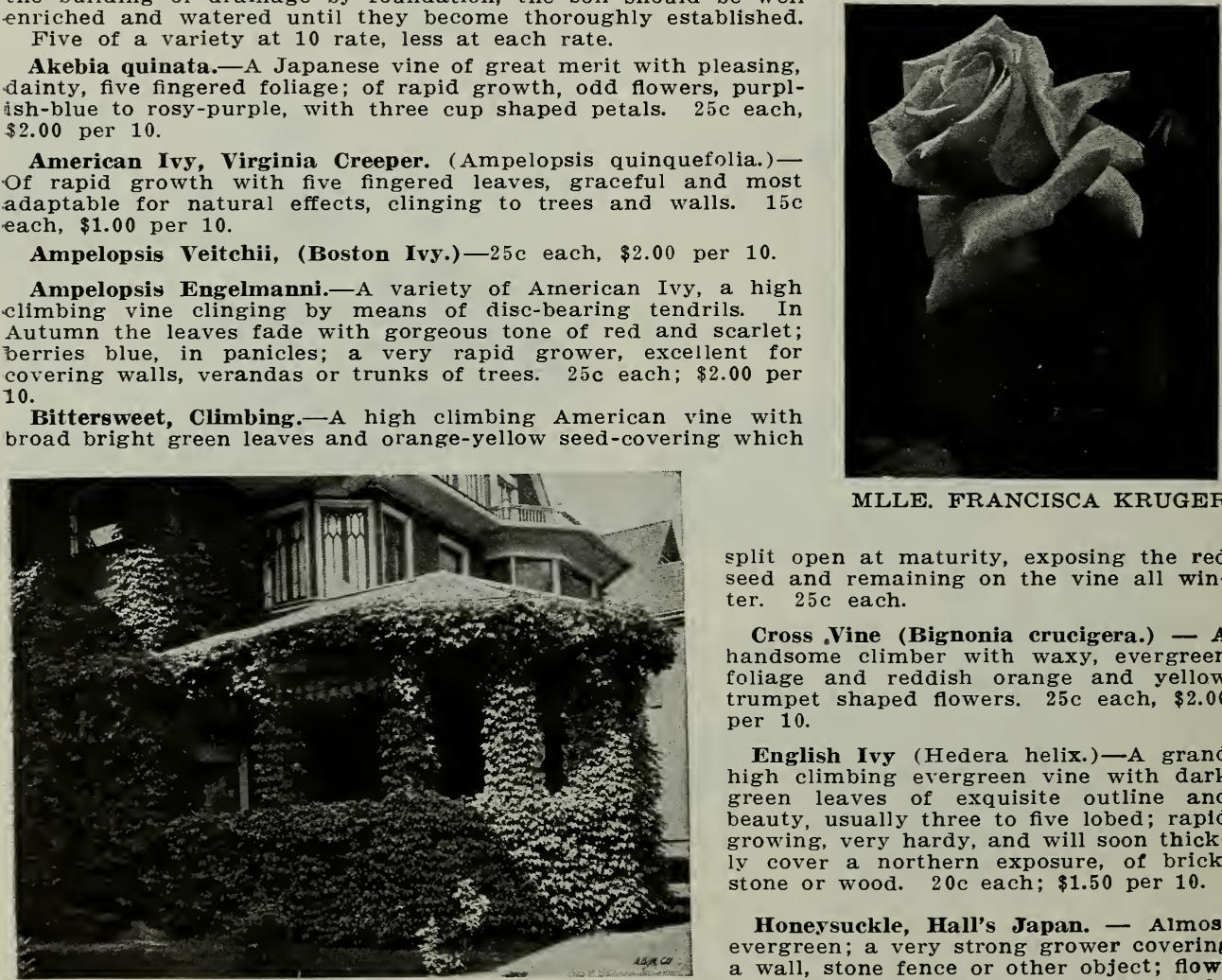

MLLE. FRANCISCA KRUGER

split open at maturity, exposing the red seed and remaining on the vine all winter. $25 \mathrm{c}$ each.

Cross Vine (Bignonia crucigera.) - A handsome climber with waxy, evergreen foliage and reddish orange and yellow trumpet shaped flowers. $25 \mathrm{c}$ each, $\$ 2.00$ per 10.

English Ivy (Hedera helix.) -A grand high climbing evergreen vine with dark green leaves of exquisite outline and beauty, usually three to five lobed; rapid growing, very hardy, and will soon thickly cover a northern exposure, of brick, stone or wood. $20 \mathrm{c}$ each; $\$ 1.50$ per 10

Honersuckle, Hall's Japan. - Almost evergreen; a very strong grower covering a wall, stone fence or other object; flowers white becoming yellow. 15c each: AMPELOPSIS. $\$ 1.00$ per 10 . 


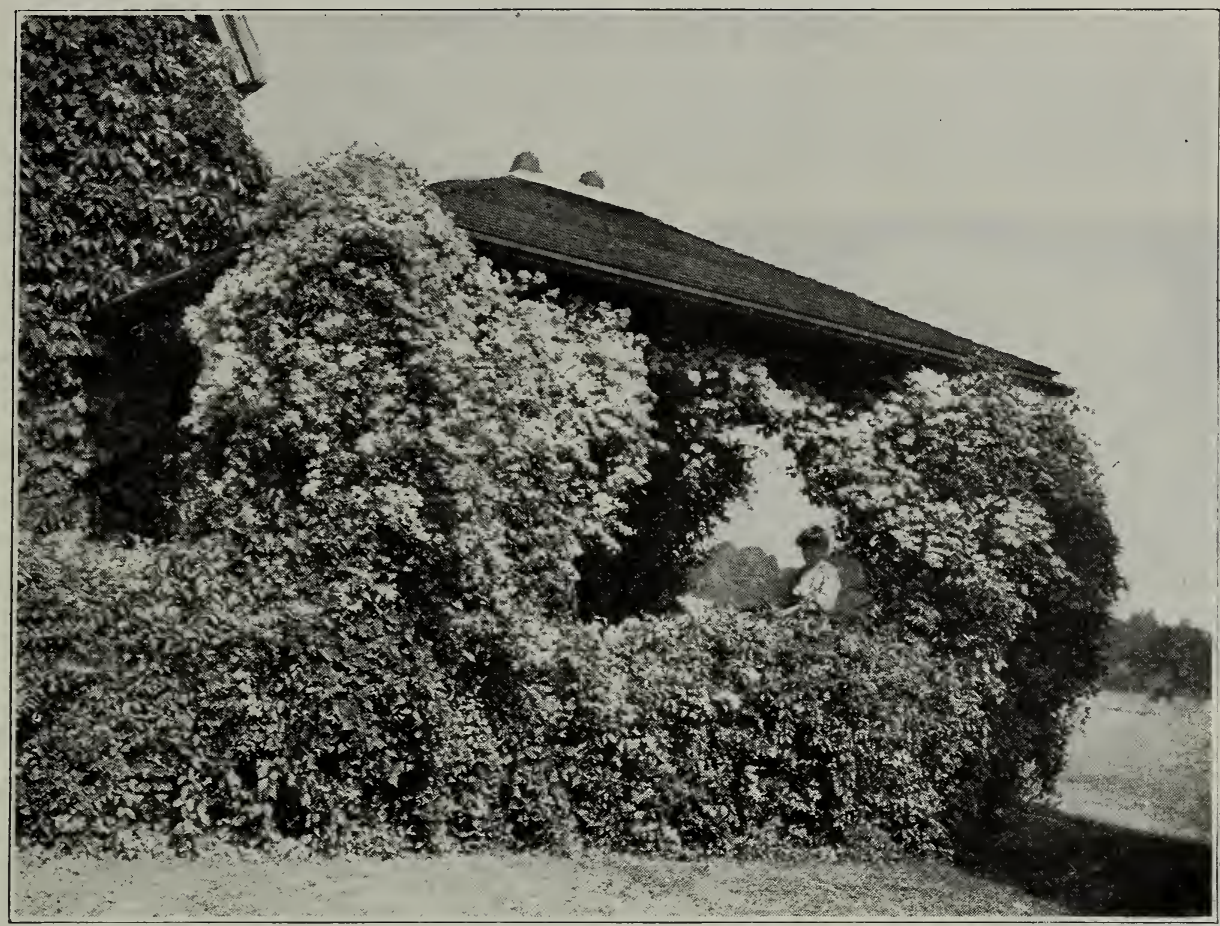

The Fragrance of Clematis Paniculata Resembles English Hawthorn.

Honeysuckle, Scarlet Trumpet.-Long, scarlet, trumpet-shaped flowers in profusion; very showy; excellent for porches; remains green here till Christmas. $20 \mathrm{c}$ each; $\$ 1.50$ per 10.

Honeysuckle, Monthly Fragrant.-Bright red flowers buff inside. $25 \mathrm{c}$ each, $\$ 1.50$ per 10 .

Wistaria White.-Attractive and rapid grower with numerous pendulus clusters of white pea shaped flowers, excellent for porch, arbor or trellis. $25 \mathrm{c}$ each, $\$ 2.00$ per 10 .

Wistaria Purple.-The well known variety with lilac-purple flowers. $25 \mathrm{c}$ each, $\$ 2.00$ per 10 .

Wistaria multijuga (Japanese Wistaria.)Flowers light purple in loose drooping racemes, often two to three feet long. $75 \mathrm{c}$ each.

Silk Vine.-A vigorous, high-climbing, twining vine; shiny, deep green leaves; adapted for ar. bor or trellis work. 2 ac.

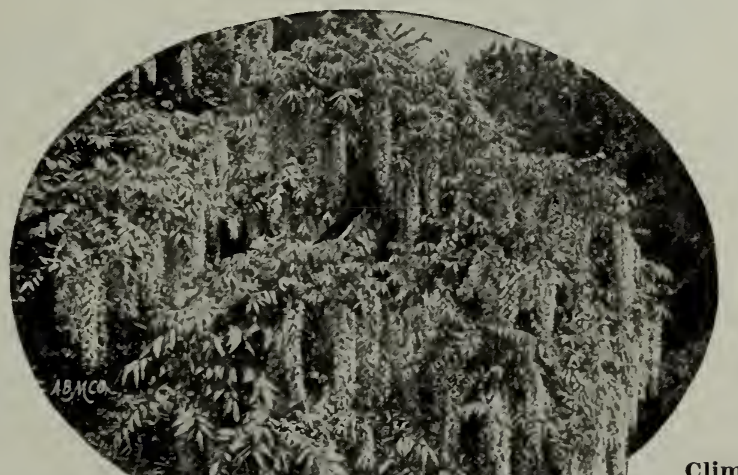

\section{Clematis}

Graceful free-growing vines, well adapted for trailing on balconies, porches, etc., or for covering walls and fences. A loamy, fertile soil should be given them and for best results it should be frequently enriched. In early spring cut away all weak branches and train on a support to prevent whipping in the breeze, as splitting of the bark by twisting is often fatal.

Henryi.-Abundant large, creamy-white, fragrant flowers. $40 \mathrm{c}$ each, $\$ 3.50$ per 10 .

Jackmanii.-Large, velvety purple; free flowering; the most popular. $40 \mathrm{c}$ each, $\$ 3.50$ per 10 .

Mme. Edouard Andre.-Violet-red, strong and vigorous. $40 \mathrm{c}$ each, $\$ 3.50$ per 10 .

Paniculata (Japanese Clematis or Japanese Virgin's Bower.) - One of the most beautiful hardy vines: flowers pure white in large panicles, fairly covering upper portion of the plant, its fragrance resembling the English Howthorne. A rapid, strong grower, quickly reaching a height of 15 to 20 feet and spreading out when trained on wires or strings. Perfectly hardy. $25 \mathrm{c}$ each, $\$ 2.00$ per 10 .

Climbing Euonymus Green. (Euonymus radicans.) - A graceful, evergreen, clinging vine, with small, rich green foliage; very attractive and suitable for covering northern exposures of brick or stone. Of very dense growth, it clings closely, making no straggling shoots; this and the following are also used for edging, and will become a bush shape if set to a small stake. 20c each; $\$ 1.50$ per 10.

Climbing Eunoymus Variegated. (Euonymus radicans variegata.) - A variety of the above, it's rich, green foliage, beautifully variegated with silvery-white. $25 \mathrm{c}$ each, $\$ 2.00$ per 10 .

Trumpet Creeper (Tecoma radicans.) - A stout high climber, well known for its orange-red trumpet-shaped flowers. $15 \mathrm{c}$ each, $\$ 1.00$ per 10 . 


\section{The Popular Peony}

T ARGE and showy without being coarse, ranging in color through almost every tint of pink, white, red and crimson, with even a startling approach toward yellow, the modern Peony rivals the rose in fragrance, beauty and variety of form. A collection of a few select varieties will supply an abundance of cut flowers, a yearly source of wonder and delight. Whether as specimen clumps on the lawn, among other perennials, or as an edging for shrubbery, the effect is charming.

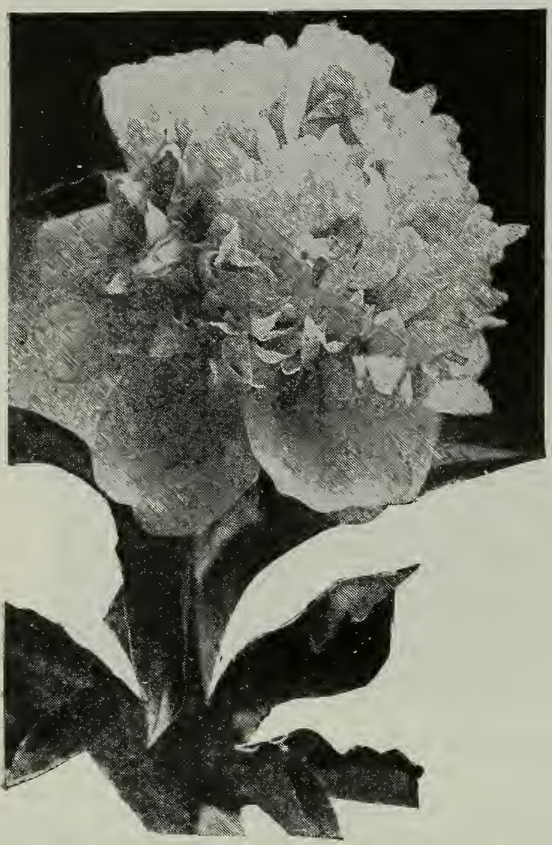
As a border for a walk or drive, or a low ornamental lawn hedge, they are unusual and attractive. On grounds of large extent bold masses are gorgeous, surpassing the rhododendron in size and magnificence of bloom.

Planting Instructions. Hardy as the oak, they are so easy to grow that little need be said. Often in neglected gardens, one sees large clumps that have flourished and bloomed for years. Yet they amply repay all attention given them. Peonies thrive in almost any soil but succeed best in a deep, rich, moist loam. If you want to give them ideal conditions, dig to a depth of two to three feet, thoroughly mix with the soil about one-third of well rotted manure, or a little finely ground bone, adding a little sand or fine gravel if the soil is inclined to be sticky or heavy. Fill a few inches above the surface to allow for settling. Cover the crowns three inches, firming the soil well, and planting two to three feet apart. Keep the soil well stirred the early part of the first two summers. While hardy without, a winter mulch of coarse, strawy manure is a benefit, especially the first winter, and is well repaid with increased size and profusion of bloom. When spring arrives remove the coarse portions, stirring the finer parts well into the soil, taking care not to disturb the pinkish-white buds just beginning to appear.

Here in the Middle West, we grow Peonies in immense quantities, our nurseries being the hub for shipments to all points of the compass. Ideal climate, a rich soil, and the most modern and thorough cultivation make for superior vitality in our Peony roots. They are of liberal size and full of real life and vigorous promise.

The name in parenthesis folowing the variety name is the originator or introducer with date of introduction. The following varieties are all double.

Five of a variety at the 10 rate; less at each rate write for 100 rates giving list of wants.

Achille (Calot, 1855.)-Delicate flesh, finishing white; moderately large flower, very fragrant and quite early; free upright grower and very vigorous; profuse bloomer and a cut flower variety. $20 \mathrm{c}$ each, $\$ 1.50$ per 10 .

Alba Sulphurea. (Calot, 1860.) -Broad white guard petals, center petals narrow, forming a full high cushion of sulphur yellow; agreeable fragrance; follows Festiva maxima; good grower, strong stems, and excellent for cut flowers. 350 each, $\$ 3.00$ per 10 .

Andre Lauries (Crousse, 1881.)-Abundant, rosy red, fragrant blooms; one of the latest and a good low priced variety of its season; healthy, vigorous growth and "long stems; an old standard. $15 \mathrm{c}$ each, $\$ 1.00$ per 10 .

Baronne James de Rothschild (Guerin, 1850.) - Guard petals silvery rose, a purplish rose tuft being borne with a salmon center; moderately fragrant; midseason; of medium dwarf, but vigorous habit, very free flowering, and especially well adapted to lawn and landscape work. $15 \mathrm{c}$ each, $\$ 1.00$ per 10 .

Couronne d'Or (Calot, 1873.)-Snowy white with yellow reflex, some central petals edged and flaked carmine, golden stamens showing through and lighting up the flower; very large, imbricated, ball shaped bloom; very late; vigorous growth, strong stems; excellent. 50c each $\$ 4.00$ per 10 .

Delicatissima.-Clear delicate pink; a good bud and large flowers borne on strong, healthy stems; very fragrant and free blooming; midseason to late; vigorous, healthy grower and a good cut flower variety. Very similar to Floral Treasure. $50 \mathrm{c}$ each, $\$ 4.50$ per 10.

Dr. Bretonneau (Verdier, 1854.)-Delicate silvery rose to silvery pink, tinted lilac and cha- mois, center tipped cream, large, full, exceedingly fragrant flower; late midseason; vigorous, good stems, free blooming, much used for cut flowers. $35 \mathrm{c}$ each, $\$ 3.00$ per 10 .

Dorchester (Richardson).-Hydrangea pink; large, full, fragrant flower; late; rather dwarf but vigorous, compact growth with good foliage; blooms freely. $40 \mathrm{c}$ each, $\$ 3.00$ per 10 .

Duc de Wellington (Calot, 1859.)-Broad white guard petals, center sulphur-white, narrow and very full; a large finely formed, fragrant, late midseason variety; tall, vigorous; blooms freely; an excellent cut flower. $40 \mathrm{c}$ each, $\$ 3.50$ per 10 .

Duchesse de Nemours (Calot, 185̄6.)-Sulphur white with greenish reflex, becoming pure white; no crimson flecks; shapely bud, full, cup-shaped, fragrant bloom; growth strong, vigorous; blooms freely in clusters; one of the best late varieties. 40c each, $\$ 3.50$ per 10 .

Excelsior (Terry.)-Brilliant crimson; large symmetrical bloom; a good grower, one of the earliest crimsons, and a good lawn variety. $25 \mathrm{c}$ each, $\$ 2.00$ per 10 .

Festiva Maxima (Miellez, 1851.)-Pure paperwhite flaked with purplish-carmine on some of the inner petals. Large, rose-shaped bloom; very fragrant; early. Of vigorous growth, with long, heavy stems; one of the best commercial varieties, and indispensible in all collections. $35 \mathrm{c}$ each, $\$ 3.00$ per 10 .

Floral Treasure (Rosenfield, 1900.)-Bright clear delicate pink, shading lighter at center; large and fragrant; free bloomer in clusters; vigorous, with good foliage; extensively used for cut flowers. Very similar to Delicatissima. $35 \mathrm{c}$ each, $\$ 3.00$ per 10 . 
Golden Harrest (Rosenfield, 1900.)-Blush pink guard petals with a distinct blush white collar, golden blush center, a few inner petals tipped and striped with light crimson. A large, delicately fragrant tri-color, its total effect creamy-pink. Medium early a good grower and free bloomer. 35c each, $\$ 3.00$ per 10 .

Grandiflora Rubra.-See Marechal Vaillant.

Jenny Lind (Barr.)-Broad guard petals, bright silvery pink, silvery reflex; inner petals narrow, shaded with salmon and chamois, intermixed with narrow whitish petals; fragrant; midseason; a tall growing, free blooming, striking variety. $25 \mathrm{c}$ each, $\$ 2.00$ per 10.

La Tulipe (Calot, 1872,)-Delicate rose becoming creamy-white, center petals tipped carmine, carmine tulip-like markings on outside of guard petals; a very large; fragrant, globular flower on long stems; late, and a vigorous grower; a fine delicate flower, good for all purposes. $40 \mathrm{c}$ each, $\$ 3.00$ per 10 .

L'Esperance.-Beautiful rose pink of good size and form; full high tufted center; a very fragrant flower and one of the earliest Chinensis to bloom; strong, hardy, vigorous, and a profuse bloomer, hence an excellent cut flower variety. This and Edulis superba may prove identical. 25c each, $\$ 2.00$ per 10

Marechal Vaillant (Calot, 1867.)-Blood red; one of the largest, of fine form; late; a strong grower. and very showy. $25 \mathrm{c}$ each, $\$ 2.00$ per 10 .

Marie Lemoine (Calot, 1869). - A fine sulphur white flower lightly shaded pink and chamois, with an occasional carmine edge; fragrant; very: large and compact on strong stems of medium length; blooms freely and very late; desirable for all purposes. S0c each, \$7.00 per 10 .

Mons. Jules Elie (Crousse 18\&\&).-Glossy flesh pink, shaded deeper rose at base of petals, reflected silvery; a very large, globular flower on long, strong stems, fragrant; excellent for all purposes, $\$ 1.00$ each, $\$ 9.00$ per 10 .

\section{German Iris (Fleur de Lis)}

$\mathrm{T}$

HE peculiar charm and beauty of the Iris is proverbial. Their grand and royal colors make them invaluable in herbaceous borders, along walks and drives, for massing on the lawn or among shrubbery, or for naturalizing, both on account of their perfect hardiness and easy culture, and for their lavish wealth of bloom. The German Iris precede and bloom with the Peonies.

German Iris succeed in partial shade but produce their best in full sun. They are not particular as to soil-mill grow almost anywhere-but do best in a well drained, rich loam or garden soil, succeeding in quite dry localities.

Five of a variety at the 10 rate, less at the each rate. 50 of a variety at 100 rate.

Celeste.-Standing petals pale lavender, falling petals deeper; fragrant; mid-season, tall. $25 \mathrm{c}$ each, $\$ 2.00$ per 10 .

Dalmatica.-A fine clear shade of lavender; very large flowers; very tall, fragrant; midseason. $25 \mathrm{c}$ each, $\$ 2.00$ per 10.

Harlequin Milanais.-Standing petals white, flaked violet; falling petals rich violet reticulated with white; large, fragrant, orchid-like flowers; blooms freely; tall; midseason. $15 \mathrm{c}$ each, $\$ 1.00$ per $10, \$ 5.00$ per 100 .

Madame Chereau.-Petals peculiarly twisted and crimped white. elegantly frilled with violet; slightly fragrant; one of the tallest, with large, very beautiful blooms. $20 \mathrm{c}$ each, $\$ 1.50$ per 10 .

Mozart.-Standing petals bronze fawn; falling petals purplefawn, netted white. $10 \mathrm{c}$ each, 50c per $10, \$ 3.00$ per 100 .

Queen of May.- Very distinct in color; standing petals lilacpink, falling petals, lilac blended in white, the total effect being almost pink, a large, fine, very fragrant flower blooming midseason: tall. $15 \mathrm{c}$ each, $\$ 1.00$ per $10 . \$ 7,00$ per 100.

San Souci.-Standing petals golden yellow, falling petals yel$10 \mathrm{w}$ veined with crimson-brown; one of the brightest yellows; fragrant: medium height; a rery profuse bloomer, beginning early and continuing late. $10 \mathrm{c}$ each, $60 \mathrm{c}$ per $10, \$ 3.50$ per 100

Sapho.-Standing petals deep violet blue, falling dark relvety

royal purple: large, fragrant; tall; early: 1jc each, $\$ 1.00$ per 10 , $\$ 6.00$ per 100 .

Speciosa.-Standing petals lavender-purple, falling petals dark reddish-purple: fragrant; blooms freely; late. $10 \mathrm{c}$ each. $60 \mathrm{c}$ per 10. $\$ 4.00$ per 100 .

German Iris to Color.-Shades of light blue and yellow. כc each. $40 \mathrm{c}$ per $10 \$ 3.00$ per 100

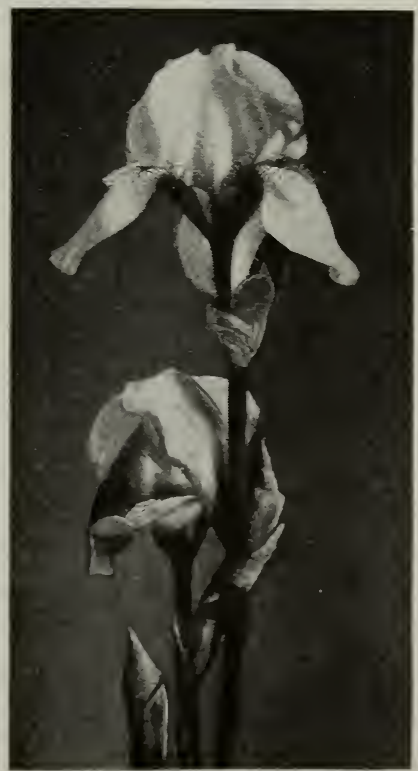

GERMAN IRIS

The "Orchid of the Garden." 


\section{Miscellaneous Herbaceous and Perennial Plants}

\section{Including Hardy Lilies for the Open Ground}

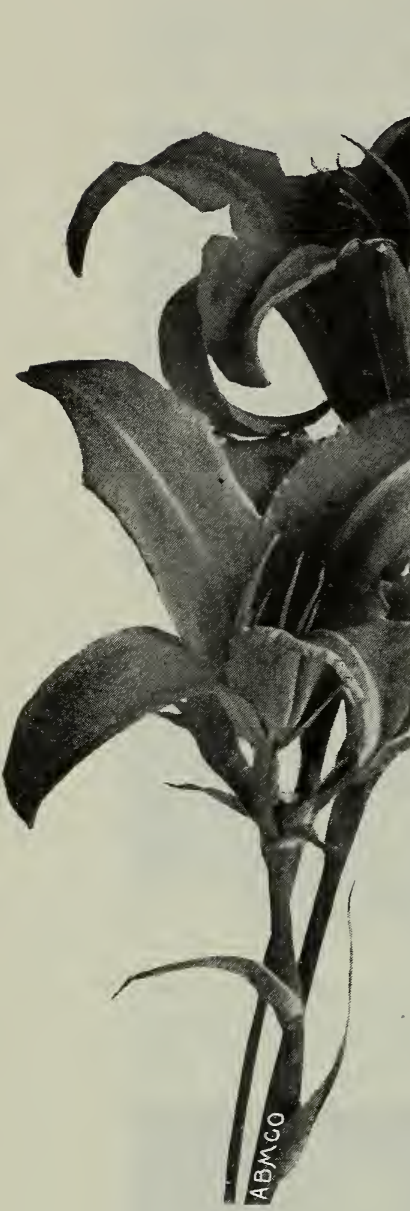

GARDEN is incomplete without at least a portion of these plants with their wealth of flowers and foliage. An abundance of flowers is secured with very little expenditure. They increase in size from year to year, are of such easy culture, and thrive in almost any soil. While requiring little care, as they are to remain in one position for a number of years, it is well to spade the ground to a depth of one or two feet, preferably two, apply a liberal quantity of well rotted manure, and mix thoroughly.

Lilies once established, require little care. While a few varieties, such as the Tiger may do well in a heavy soil, the larger number prefer a moist, light, rich soil intermixed with sand and gravel, one from which any excess of moisture runs off. Manure must not come in contact direct with the bulb. If well composted it may be placed within reach of the rootlets, the bulb being placed with sand or leaf mold around it; or it may be applied as a mulch to be carried down by the rains. Five of a variety at the 10 rate, less at the each rate.

Orange Day Lily (Hemerocallis fulva.)-The tawny orange flowers, with wavy margins, are produced very freely in late summer on stems 3 to 4 feet tall. Grows

Orange Day Lily

luxuriantly in almost any garden soil, in moist places, and in partial shade, soon forming large clumps. Single and double. $10 \mathrm{c}$ each. $60 \mathrm{c}$ per 10 .

Bleeding $\mathbf{H}$ e a $\mathbf{r}$ (Dicentra spectabilis.)-An old-time favorite, rich in sentiment and associations, with large, deep rosy-red, heartshaped flowers, nodding in graceful, drooping racemes. It is perfectly at home in any part of the hardy garden, and useful in shaded situations. $15 \mathrm{c}$ each, $\$ 1.00$ per 10 .

Cornflower or Stokes' Aster.-Of low growth an excellent border or rockery plant, thriving in any.soil; from summer until frost the plants are covered with clusters of broad, lavender-blue flowers. $20 \mathrm{c}$ each, 3 for $50 \mathrm{c}$.

Hibiscus Crimson Eye.-Its large, showy creamy-white flowers with a crimson eye are borne very freely in late summer on plants 3 to 5 feet tall; succeeds in any sunny position but best in a damp place. $15 \mathrm{c}$ each, $70 \mathrm{c}$ per 10.

Hollyhock. - An old garden favorite, effective in the herbaceous border or among shrubbery for its tall spikes of flowers. Strong plants for blooming next summer, mixed colors, mixed single and double. $20 \mathrm{c}$ each, $\$ 1.50$ per 10 .

Goldenrod.-Of easiest culture, improving under garden cultivation, the Goldenrod is one of the glories of autumn. Selected plants $15 \mathrm{c}$ each, 2 for $25 \mathrm{c} ; \$ 1.00$ per 10 .

Violet, Sweet Russian.-The hardiest of violets; deep, rich blue; fragrant; a strong grower. You will have no trouble to grow this variety. $15 \mathrm{c}$ each, $\$ 1.25$ per 10 .

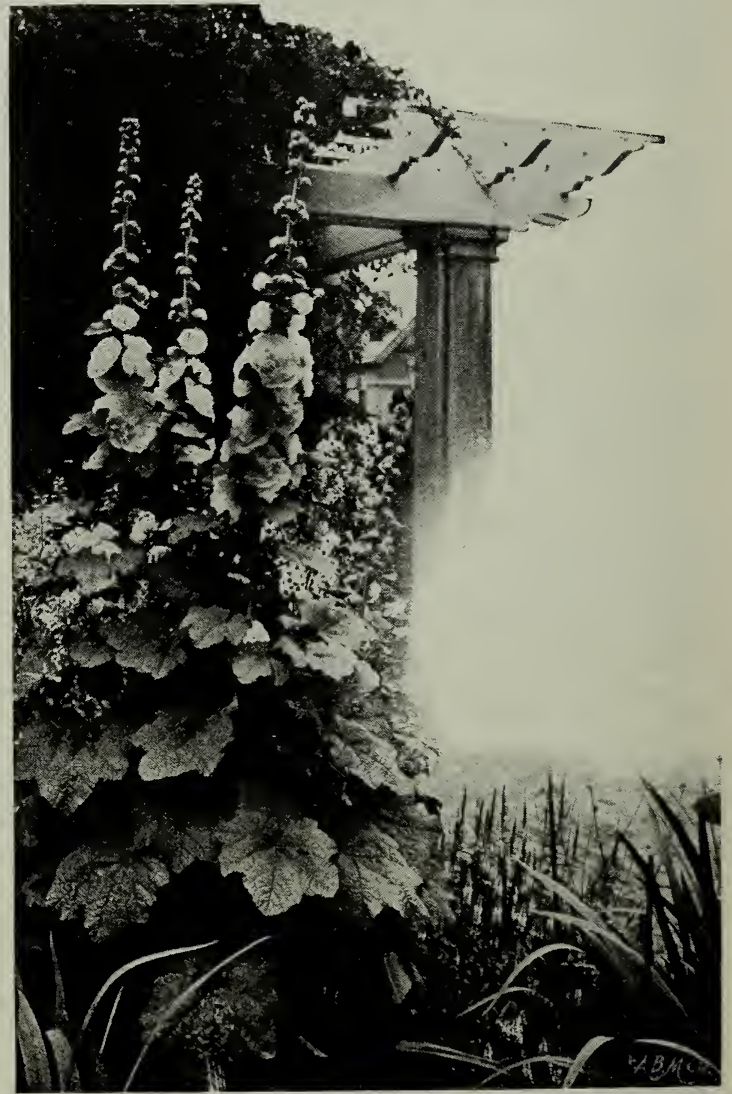

The Tall Spikes of Hollyhock are very Effective 
Violet, Common Wild.-Excellent for naturalizing. $10 \mathrm{c}$ each, $60 \mathrm{c}$ per 10 .

Ascension, Madonna or St. Joseph Lily (thick petaled.) (Lilium candidum.)-One of the most ornamental and popular. Immense, snow white flowers 4 to 5 inches long, very fragrant, borne on stems 3 to 4 feet high. The best pure white hardy lily. $20 \mathrm{c}$ each, $\$ 1.50$ per 10 .

L e m o n Lily (Hemerocallis flava.)-Flowers fragrant clear sellow, 3 to 4 inches across, produced very freely in early summer. $20 \mathrm{c}$ each, $\$ 1.50$ per 10 .

Tiger Lily (Lilium tigrinum.) -Bright orange-scarlet flowers in large clusters on stems 2 to 5 feet high. It lives and thrives from year to year in the open border, where it should be planted in masses. $10 \mathrm{c}$ each, $70 \mathrm{c}$ per 10.

Tiger Lils, Double.-A variety with showy double flowers. $15 \mathrm{c}$ each, $\$ 1.00$ per 10 .

Lily of the Valles. - $\pi$ ill thrive in almost any kind of soil and throw up its beautiful modest, fragrant, white bells in slender racemes in the out-of-the-way nooks, shady spots and corners where bolder plants would scorn to bloom. Prefers partial shade, and should be transplanted occasionally. Pips, 5c each, 40c per $10, \$ 2.50$ per 100 ; clumps for immediate effect, $25 \mathrm{c}$ each, $\$ 2.00$ per 10.

Christmas Rose (Helleborus.) -A valuable hardy plant, yielding a profusion of beautiful white flowers, two or three inches across in very early spring. They bloom before the Jonquils and very often through the snow. Give them good soil

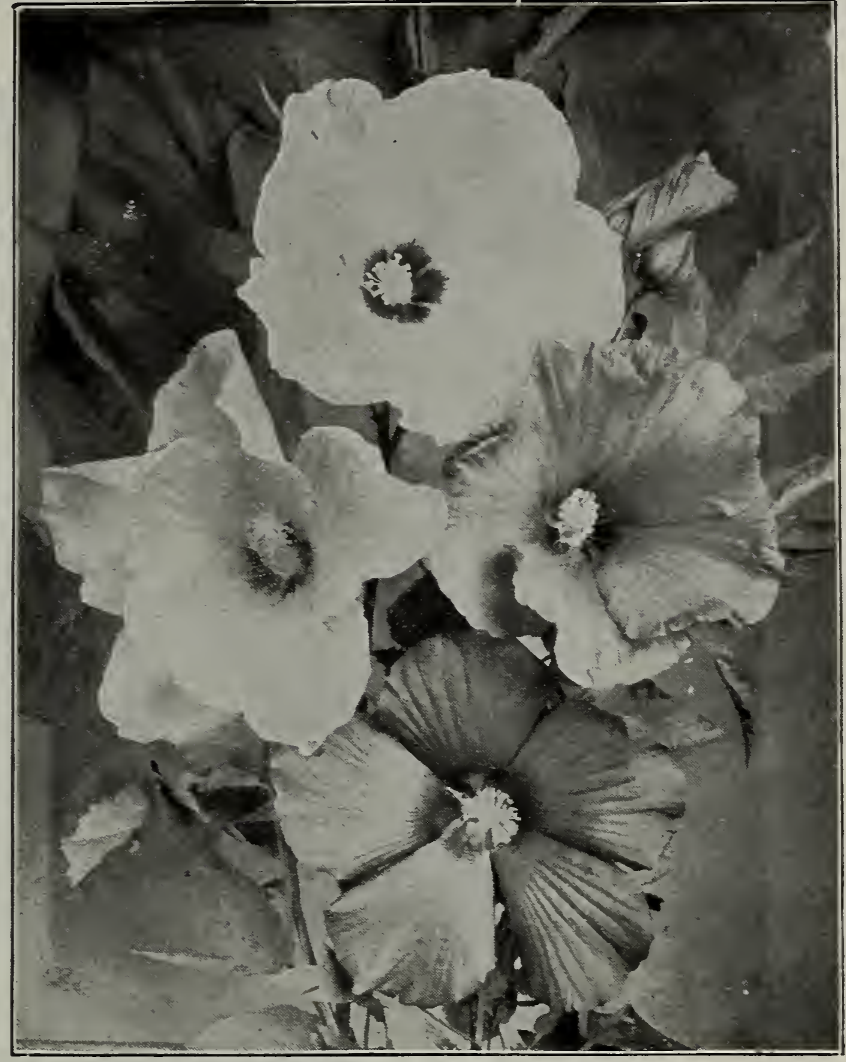

Mallow Marvels Bloom from July to October.

in a semi-shaded situation, $40 \mathrm{c}$ each. Postpaid $50 \mathrm{c}$ each.

Shasta Daisy.-A strong growing, vigorous plant with large, showy, daisy-like flowers, white with golden center, blooming profusely throughout summer and autumn. $20 \mathrm{c}$ each, 3 for $50 \mathrm{c}$.

\section{Mallow Marvels}

Immense flowers eight to ten inches in diameter; rich red pink and blush, white. Mallow Marrels are unsurpassed in brilliancy of

color. From July until October frosts arrive, the flowers continue to appear in profusion. Absolutely hardy, the Mallow Marvels are thriving in Canada and in the mountain portions of the Northern States, as successfully as Georgia and Florida. Of herbaceous character, they come up year after year. Excellent to plant with Peonies.

Two-year plants, to bloom the first summer, separate colors, red, pink and white. $60 \mathrm{c}$ each, 3 for $\$ 1.70$, 5 for $\$ 2.50$.
THE MAGAZINE

\section{FLOWE}

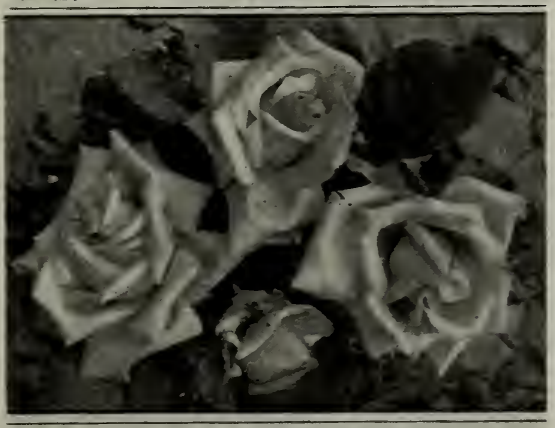

THE SUHURBAY PRESS. PUHLISHERS ....

Flowers, flowers, beautiful flowers--everything you want to know about them. Charming, kindly friends worth knowing about, too:

A magazine which treats exclusively about flowers from every standpoint, instead of entirely from that of the garden.

Suggestive subjects are given here to explain exactly the character of this charming magazine: The Flower of the Month; Care of Flowers Indoors; Growing Flowers for Profit; Where the Flowers Got Their Names; Wild Flowers Month by Month; Old Fashioned Blooms; Flowers and Sentiment; Flowers Especially for Children; Stories of Real Gardens; Freaks Among the Flowers.

\section{Special Introductory Offer}

\section{Good only till July 1, 1912.}

The regular price is $\$ 1.00$ per year.

Sign below and send $\$ 1.00$ ( $\$ 1.50$ to Canada), for a two years subscription for the Magazine Flowers to The Suburban Press, 334 Fourth Are., New York City, or with your order for trees to Wild Bros. Nursery Co.

Name 


\section{Dahlias}

Old-time favorites for autumn flowering. The flowers are so symmetrical and the range of color so varied and are so easily grown that they will always be popular where display is desired. The roots are tender, easily injured by frost, and during winter should be placed in a cool cellar and not allowed to freeze. After danger of frost is over, plant three feet apart, pinching back when three sets of leaves appear, to make them grow more bushy and to avoid staking. We have a choice assortment of white, yellow and various shades of pink and red, including quilled eactus and show types.

15c each, $\$ 1.25$ per 10. 5 of a variety at 10 rate. Our selection. 10 in 3 varieties for $\$ 1.20$.

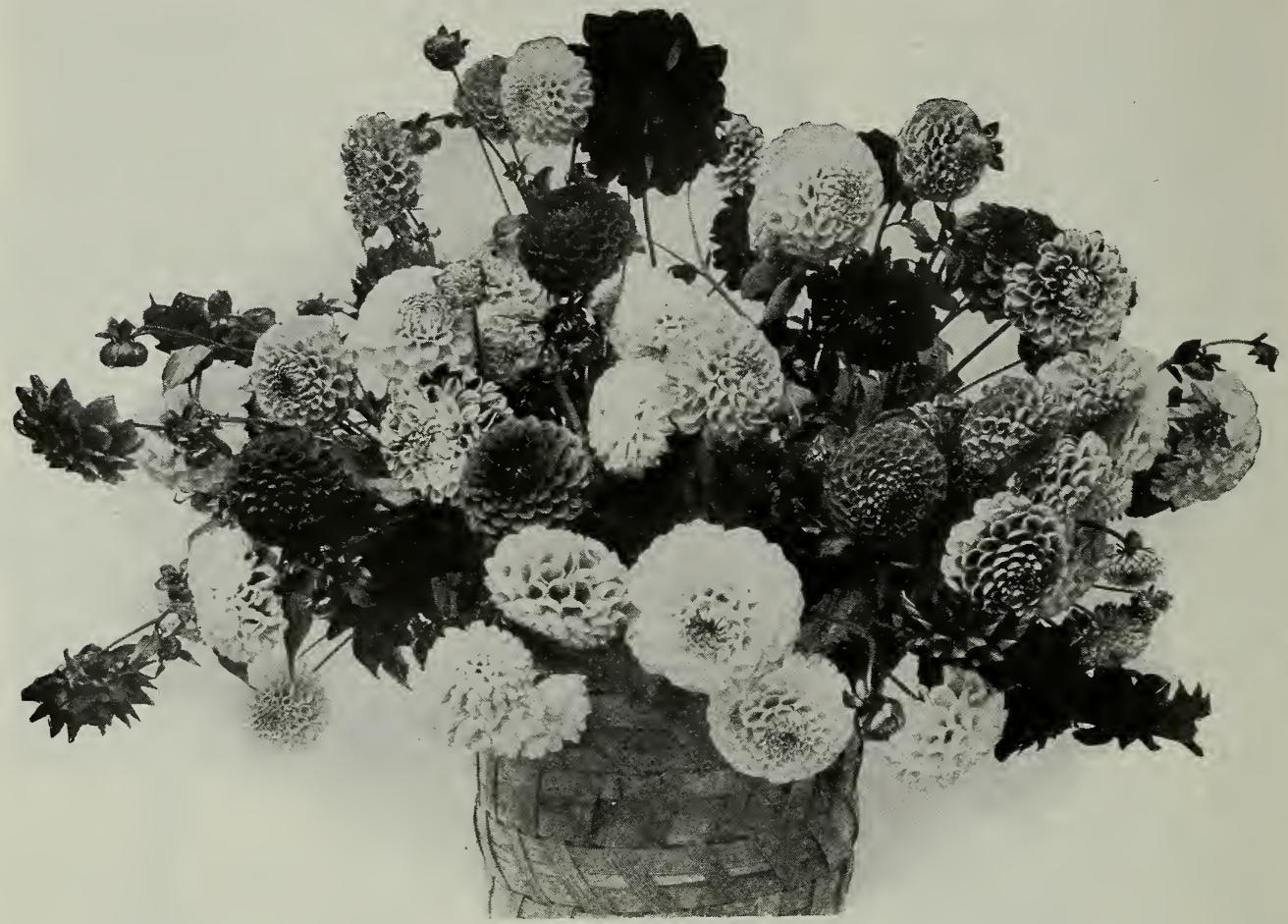

A. D. Livoni (Show.) - A delicate rose of perfect form; very free flowering.

Admiral Dewey (Show.)-Imperial purple.

Apple Blossom (Fancy.) - White tipped pink.

Bonnard's Yellow (Decorative.) - Extra large flowers, beautiful deep yellow.

Floral Park Jewell

on the same plant.

Gotlinde.-Deep golden yellow cactus flowers.

Hohenzollern (Decorative.)-Dark crimson.

Kriemhilde (Cactus.)-Delicate shell pink shading to a cream center; excellent.

Queen Emma (Peony Flowered.)-Lively rose and yellow margined; very large.

Queen Victoria (Show.)-Deep yellow.

Sylvia (Decorative.) - White shading to soft pink on the rim; large, of fine form.

\section{Gladioli}

To flower has gained more rapidly in public favor, for in addition to the intrinsic merit of the flower it is easy of cultivation and blooms freely. They thrive in almost any good soil. Plant the bulbs six to nine inches apart, the large ones four inches and the small ones three inches deep. Make several plantings of the smaller bulbs first as scon as the ground is sufficiently dry and in this way a succession of blcom may be had from midsummer until frost. In autumn, before freezing, they should be dug and dried. Separate the new bulbs from the old earth and old roots removed, and then store in a cool, dry place, secure from frost until spring. For boquets the flowers are admirable. As soon as the two lower flowers open the spike may be cut and placed in water, and it will last for days, all the flowers opening as well as if growing in the garden.

Choice Mixed.-All colors, including striped and blotched kinds $\ldots \ldots \ldots \ldots \ldots \ldots \ldots \ldots \ldots 0.10 \quad \$ 0.50 \quad \$ 3.50$ 




Water Lilies are Easily Grown.

\section{Hardy Water or Pond Lilies}

A VERY one that has a small pond, stream of water or even room on the lawn for a concrete 4 basin should have some of these beautiful flowering plants. All that is necessary to have the pond or basin, should be put there. Plant 2 feet deep and they will spread into deeper water.

Nelumbium speciosum.-Its superb flowers and magnificent foliage produce a splendid subtropical effect. Blooms rose colored at the tips, creamy white at the base of the petals; exquisitely fragrant. $80 \mathrm{c}$ each; $\$ 7.00$ per 10 .

Nymphae tuberosa Richardsoni.-Flowers pure white and quite double, the stamens being converted into petals, which are more or less fluted in the center. The flowers stand well above the water, the sepals and outer petals drooping and forming a perfect globe giving it a peonylike shape. Grand. $70 \mathrm{c}$ each; $\$ 6.00$ per 10 .

Nrmphae, Choice Hrbrids, Mixed.-Composed of unnamed hybrids among which are large flowered plants in shades of rose, pink, flesh and some fine white, also miniature flowered ones. $25 \mathrm{c}$ each; $\$ 2.00$ per $10 ; \$ 18.00$ per 100 .

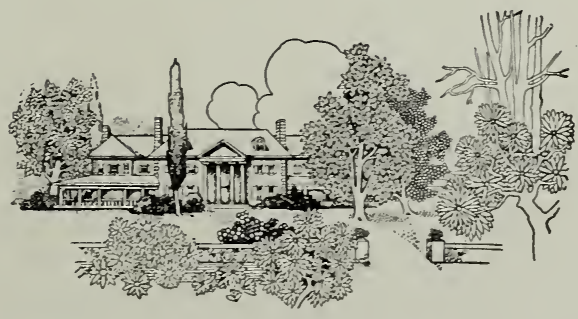




\section{Cannas}

TO flowering plant can at such small cost excel Canas for massing and formal bedding. Their abundance of foliage ranges from light and dark green to purplish-bronze, and from early July till fall is surmounted by a profusion of dazzling bloom in inany shades of red and yellow. Excellent results may be secured by scattering canas singly or in small clumps in the hardy border or among shrubbery. Their gaudy flowers are particularly effective against a background of dark green.

Their culture is simple and easy. They prefer a warm, friable, rich, moist soil. For best results spade about two feet deep and incorporate a liberal amount of well rotted manure. For mass planting, the best effect is secured by using large groups of one color, setting the plants about two feet apart. If several varieties are used, plant the taller growing ones in the center or background. Their ultimate height is mentioned in the description. Cannas are tender and should be planted in the spring and after frost stored in a cellar during winter.

Price, unless otherwise noted, 10 cents each, 50 cents per $10, \$ 3.00$ per 100

A d m i r a 1 Welland.

Orchid flowered. Bright scarlet with broad yellow border; blooms very freely; one of the best. 5 feet.

Allemania.-Large orchid flowers, scarlet with broad yellow border. 4 to 5 feet.

Alphonse Bouvier.-A grand variety of luxuriant growth. The tips of the shoots are surmounted by immense clusters of large, rich velvety crimson flowers. 4 feet. Green foliage.

Austria.-Orchid flowering. Immense flowers 6 to 7 inches across, pure canary-yellow, the two center petals show lighter scarlet dots than in Burbank. 5 to 6 feet.

Burbank. - This new orchid flowering Canna grows to a height of j feet, producing gigantic flowers of good texture: a most beautiful rich canary-yellow, i n n e r petals showing fine crimson spots. Green foliage.

Chas H e n d e r o n. - C r i m s o n. A good bedding variety. 4 feet.

Express. - Scarletcrimson. Large trusses. Dwarf, $2 \frac{1}{2}$ feet. $15 \mathrm{c}$ each, $80 \mathrm{c}$ per $10 ; \$ 5.00$ per 100 .

Florence Vaughan. Golden yellow thickly dotted with bright golden red. 5 feet. $10 \mathrm{c}$ each, $50 \mathrm{c}$ per $10, \$ 4.50$ per 100 .

King Humbert.-Very large orchid flowers,

bright orange-scarlet streaked with crimson: blooms freely, Bronze foliage with purplish-green stripes, thick and leathery. A robust grower. 5 feet. $15 \mathrm{c}$ each, $\$ 1.00$ per $10, \$ 6.00$ per 100 .

Louisiana.-Orchid flowering. A very vigorous grower producing a thick mass of glossy green foliage, each leaf edged with a narrow purple border. Flowers dazzling scarlet, about 7 inches across. feet. $15 \mathrm{c}$ each, $80 \mathrm{c}$ per $10, \$ 4.00$ per 100 .

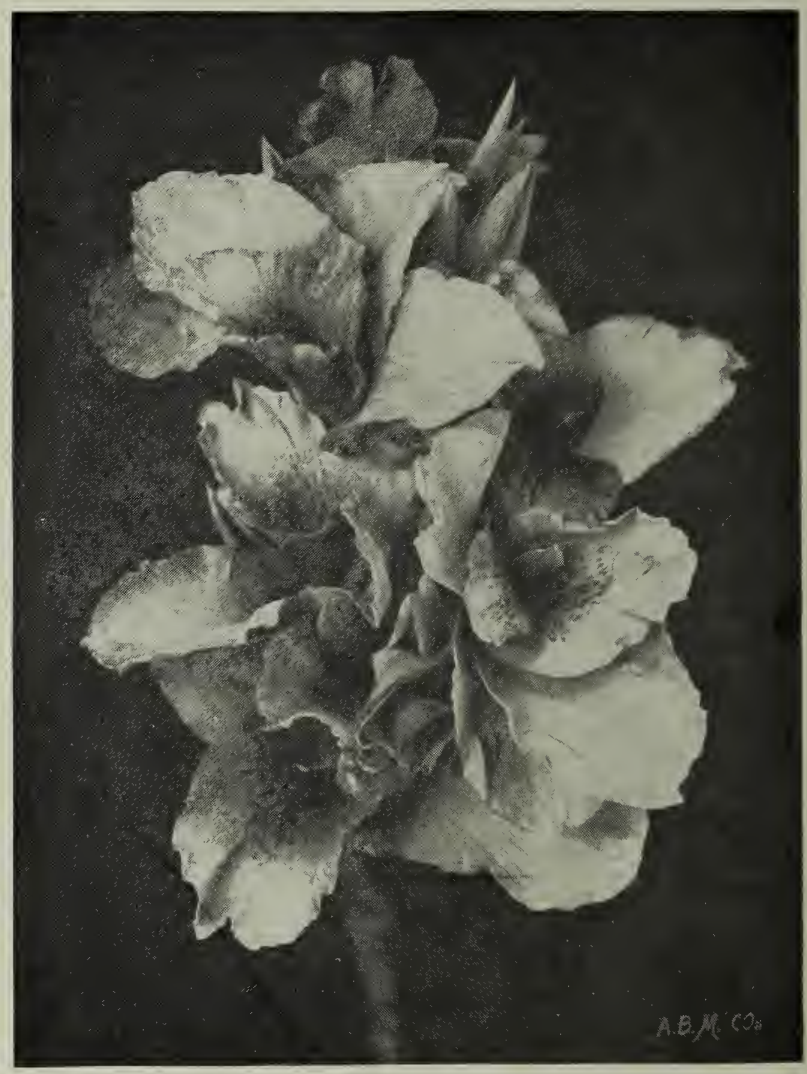

BURBANK.

Neuvessal. - No Canna is more floriferous than this, blooming earlier than most varieties. Flowers dark red of nice form and good substance. 4 to 5 feet. Bronze foliage.

Robusta. - The tallest growing sort, attaining 7 to 8 feet. Has very large purplish-bronze foliage producing a semitropical effect. Splendid for center of circular bed or background. $15 \mathrm{c}$, each, $80 \mathrm{c}$ per $10, \$ 4.00$ per 100 . 